\title{
Estrutura E FunÇÃo do Microbioma de Solos Brasileiros
}

\section{FERNANDO DINI ANDREOTE}

Texto sistematizado apresentado à Escola Superior de Agricultura "Luiz de Queiroz", da Universidade de São Paulo, como parte dos requisitos para obtenção do título de Livre Docente do Departamento de Ciência do Solo, na especialidade Biologia do Solo.

PIRACICABA

Estado de São Paulo - Brasil

Abril - 2014 


\title{
Estrutura E FunÇÃo do Microbioma de Solos Brasileiros
}

\author{
FERNANDO DINI ANDREOTE \\ Engenheiro Agrônomo \\ Doutor em Genética e Melhoramento de Plantas
}

Texto sistematizado apresentado à Escola Superior de Agricultura "Luiz de Queiroz", da Universidade de São Paulo, como parte dos requisitos para obtenção do titulo de Livre Docente do Departamento de Ciência do Solo, na especialidade Biologia do Solo.

\section{PIRACICABA}

Estado de São Paulo - Brasil

Abril - 2014 
A minha grande família;

- meus pais, Fernando e Fátima,

- meus irmãos, Ana Paula e Francisco,

- minha madrasta-amiga Fátima,

- minha irmã de coração Juliana,

por serem o pilar de todas as minhas realizações,

\section{Ofereço}

A minha esposa Cristiane e aos meus filhos, Fellipe, Giovanni e Clara, pois para eles dou meu máximo a cada dia,

Dedico 
"No que diz respeito ao desempenho, ao compromisso, ao esforço, à dedicação, não há meio termo, ou você faz uma coisa bem feita, ou não faz,"

"Se você quer ser bem sucedido, precisa ter dedicação total, buscar seu último limite e dar o melhor de si",

\section{Ayrton Senna}




\section{AGRADECIMENTOS}

Reconhecer o papel daqueles que são importantes, em todos os aspectos de nossa vida, revela a consciência de que nada se conquista sozinho. Dessa forma, gostaria de demonstrar neste momento, meus sinceros agradecimentos:

As famílias Dini, Andreote, Sacilotto e Cipolla-Fasanella, por todo apoio e prestígio;

A minha equipe de trabalho, por ser a força motriz de meus devaneios científicos, contribuindo sempre para o crescimento de nosso grupo. Dentro do grupo destaco o papel fundamental do suporte técnico de Denise L. C. Mescolotti e Luis Fernando Baldesin, mais que meus braços nesta jornada;

Ao João Luiz da Silva, por todo suporte técnico nos projetos em colaboração com a Embrapa Meio Ambiente, e por ter se mostrado uma das pessoas mais dedicadas ao trabalho com quem já convivi;

Aos componentes atuais e já egressos de nosso grupo, por terem durante nosso convívio absorvido algo que tínhamos a ensinar, e por terem deixado parte de sua experiência conosco: Ademir Durrer, André S. Paula, Armando C.F. Dias, Cristiane C. Fasanella, Cristiane Toledo, Danice M. Luvizotto, Daniela Veja, Danielle Santos, Diogo P. Costa, Dorotéia A. Ferreira, Emiliana M. Romagnoli, Fábio L. Soares Jr., Filipe Salvetti, Joelma Marcon, Joshua A. Halsey, Julia E. Lima, Juliana E. Araújo, Luana L. Cadete, Lucas D. Lopes, Marcus Venícius M. Lourenço, Maryeimy V. Lopez, Mayra Costa, Mylenne C. P. Silva, Pedro A. M. Andrade, Simone R. Cotta, Sonia Pires e Thiago Gumiere.

Aos colegas docentes do Departamento de Ciência do Solo, que me guiaram pelos trâmites no início de minha carreira, e estiveram sempre dispostos a discutir os mais variados assuntos, revelando a vontade de todos de ver o Departamento crescer;

A Profa. Elke J. B. N. Cardoso, pelo enorme suporte que me deu em minha chegada ao Departamento, me permitindo fazer parte de sua equipe, e usufruir do Laboratório de Microbiologia do Solo. 
As secretárias do Departamento de Ciência do Solo, Cristina, Célia, Camila, Fernanda e Marta, por todo suporte e auxílio nos trâmites burocráticos de nossa instituição;

Ao Prof. Marcio Lambais, a Profa. Simone Lira e a secretária Fernanda Prado, pela convivência na Comissão Coordenadora do Programa de Pós-graduação em Microbiologia Agrícola;

Aos grupos colaboradores, com destaque para os pesquisadores Itamar Soares de Melo, Welington Luiz de Araújo, Rodrigo Mendes, Rodrigo Gouvêa Taketani, Vivian Helena Pellizari, Valéria Maia de Oliveira, Marcilio de Almeida, Cristina de Almeida, André Lima, Marli de Fátima Fiore e Siu Mui Tsai, por todo o esforço que em conjunto tivemos em nossos sucessos e insucessos na busca de ver o desenvolvimento prático de nossos projetos;

Aos órgãos de financiamento, principalmente FAPESP, CNPq e CAPES, pela alocação do suporte financeiro em meu laboratório, proporcionando o desenvolvimento dos projetos que embasam este documento;

Aos amigos que me auxiliaram no preparo deste documento, revisando a parte escrita, ou contribuindo com valiosas sugestões que engrandeceram o conteúdo apresentado: Cristina V. Almeida, Armando C. F. Dias, Simone R. Cotta, Francisco D. Andreote e Cristiane C. Fasanella.

A todos, que de alguma forma contribuíram para meu desenvolvimento pessoal, profissional, e ainda, àqueles que auxiliaram alguns de meus alunos. 


\section{SUMARIO}

APRESENTAÇÃO ............................................................................................................... 13

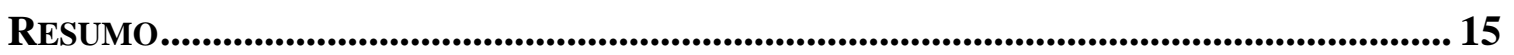

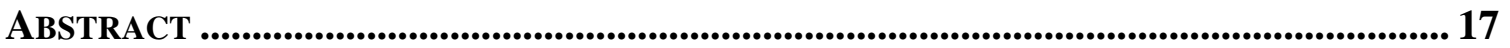

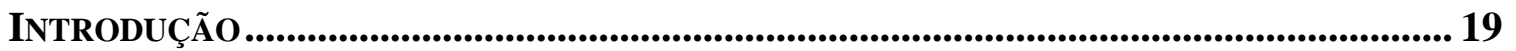

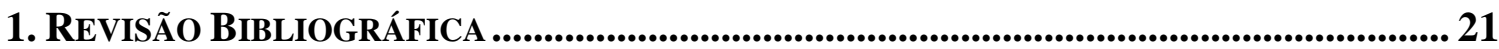

1.1. Biomas e solos brasileiros - características e peculiaridades ................................. 21

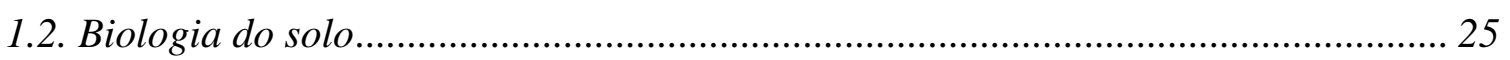

1.3. Diversidade microbiana em solos de biomas brasileiros.......................................... 26

1.4. O acesso a diversidade microbiana - métodos independentes de cultivo.................. 28

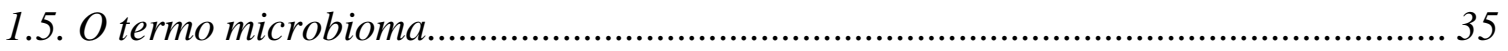

Sessão I - Microbioma de Solos de Biomas Naturais ............................................... 39

I.1. Contribuições do candidato no estudo do microbioma dos solos da Amazônia ......... 41

I.2. Contribuições do candidato no estudo do microbioma dos solos da Caatinga ........... 42

I.3. Contribuições do candidato no estudo do microbioma dos solos da Mata Atlântica. 44

I.4 Perspectivas futuras para o estudo do microbioma de solos em biomas naturais ....... 51

SESSÃo II - MiCrobioma de Solos de MANGUEZAis ..................................................... 53

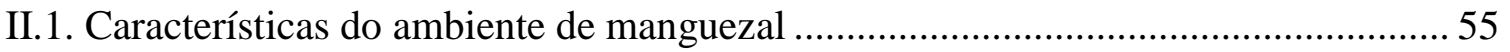

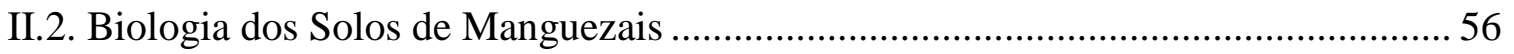

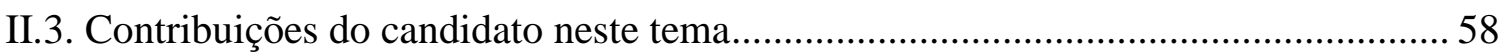

II.3.1. Descrição da diversidade microbiana em solos de manguezais ............................ 58

II.3.2. Acesso a genes relacionados a funções específicas em solos de manguezais ....... 67

II.3.3. Quantificação de grupos microbianos em solos de manguezais ............................ 74

II.3.4. Exploração biotecnológica de grupos microbianos de solos de manguezais ....... 75

II.4. Perspectivas futuras para o estudo do microbioma dos solos de manguezais ........... 78

SESSÃo III - Microbioma de SOLOS CULTIVAdOS COM CANA-DE-AÇÚCAR................... 81

III.1. Importância da cana-de-açúcar e as mudanças no sistema produtivo ....................... 83

III.2. Contribuições do candidato nesta área de estudo .................................................... 87

III.2.1. Análises zoom-out do microbioma de solos cultivados com cana-de-açúcar...... 87

III.2.1.1. Aplicação de modelos ecológicos para o estudo da estruturação de comunidades microbianas em solos cultivados com cana-de-açúcar.............................. 95

III.2.2. Análises zoom-in da comunidade microbiana associada à cana-de-açúcar ....... 97

III.2.3. A biodiversidade como promotora do funcionamento do sistema solo................. 100 
III.3. Perspectivas futuras para o estudo do microbioma em solos cultivados

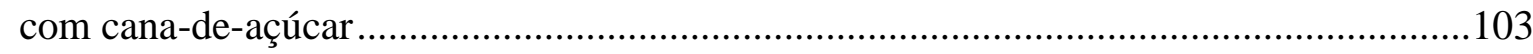

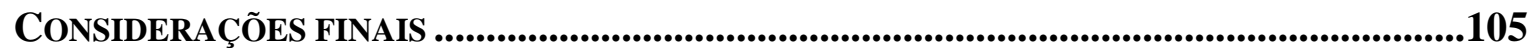

REFERÊNCIAS BIBLIOGRÁFICAS ..................................................................................107

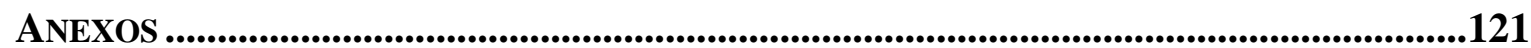

Anexo I - Resumos dos trabalhos que embasam este documentos ..................................121

Anexo II - Características físicas e químicas dos solos de biomas naturais

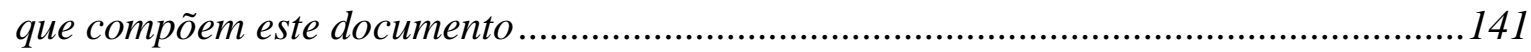




\section{APRESEnTAÇÃo}

Este manuscrito tem o objetivo de transcorrer a experiência científica do candidato, sendo esta desenvolvida ao longo de sua trajetória como pesquisador, oficialmente iniciada no pósdoutoramento, e complementada com seus quatro anos de docência na Universidade de São Paulo.

A decisão sobre a forma de apresentação deste documento foi tomada após uma série de reflexões e discussões com colegas que compõem o grupo de pesquisa. O primeiro desafio foi decidir entre a escolha de uma das áreas de atuação ou a apresentação de toda a obra elaborada até o presente momento. Assim sendo, foi desenvolvida uma estrutura de texto que visa dar clareza ao leitor, de forma que o mesmo possa se situar ao ponto explorado pelo candidato.

Este documento está estruturado com uma parte inicial, onde são abordados itens e assuntos comuns a todas as linhas de atuação do candidato (Resumo, Abstract, Introdução e Revisão Bibliográfica), e posteriormente são apresentadas três outras sessões, onde os temas específicos são abordados separadamente, expondo mais detalhes sobre os biomas estudados, e destacando a contribuição do candidato nos temas Microbioma de Solos de

Biomas Naturais (Sessão I), Microbioma de Solos de Manguezais (Sessão II) e Microbioma de Solos Cultivados com Cana-de-açúcar (Sessão III). Esta divisão se dá para contemplar os trabalhos desenvolvidos, sendo que dentro de biomas naturais duas sessões foram geradas para dar o devido destaque ao estudo da microbiota de solos de manguezais. O texto está organizado de forma simplificada, com poucos detalhes experimentais, os quais são supridos nas referências citadas (resumos em anexo).

O desejo é tornar a leitura mais dinâmica, explanando sobre os desafios dos temas abordados, descrevendo os objetivos já atingidos, e discutindo as etapas em andamento e projetos futuros, os quais buscam a elucidação da estrutura e do funcionamento das ainda enigmáticas comunidades microbianas que habitam o sistema solo. 


\title{
ESTRUTURA E FUNÇÃO DO MICROBIOMA DE SOLOS BRASILEIROS
}

\begin{abstract}
RESUMO
O conhecimento da diversidade microbiana é um dos temas mais explorados dentro da ciência nos últimos anos. O recente acesso a grande maioria dos microrganismos, com base em metodologias independentes de cultivo, deu origem ao termo microbioma, uma das áreas mais recheadas de novidades, e uma das linhas de pesquisa mais promissoras na busca por inovações teóricas e tecnológicas. Dentre todos os ambientes, o solo é aquele que hospeda a maior diversidade microbiana, composta por valores de aproximadamente $10^{9}$ células microbianas por grama de solo, divididas em algo em torno de 10 mil a 30 mil diferentes 'espécies'. Este manuscrito visa portanto, demonstrar os avanços realizados no estudo do microbioma presente em solos brasileiros, oriundos de áreas naturais, como manguezais ou solos da caatinga nordestina; e solos utilizados para a produção agrícola, com destaque para aqueles cultivados com cana-de-açúcar. Dentro do estudo das áreas naturais, destacam-se os avanços realizados nos solos de manguezais, onde o microbioma foi descrito, tanto com base na taxonomia, como na base funcional deste ambiente em diferentes estados de contaminação. Com relação às áreas agrícolas, solos cultivados com cana-de-açúcar estão sendo estudados, visando a detecção de padrões biogeográficos na estruturação do microbioma de tais áreas, bem como auxiliando na descrição dos grupos microbianos intimamente relacionados com as plantas.
\end{abstract}

Palavras-chave: biodiversidade, ecologia microbiana, microbiologia do solo, métodos independentes de cultivo 


\title{
STRUCTURE AND FUNCTIONING OF THE MICROBIOME IN BRAZILIAN SOILS
}

\begin{abstract}
The knowledge on microbial diversity is one of the most revolutionary themes in science in the last years. The recent assess to the majority of microorganisms, based on cultureindependent methodologies, originated the term microbiome, one of the field most filled with novelties, and one of the most promising research line in the search for theoretical and technological innovations. Among all environments, soils harbor the bigger microbial diversity, being it composed by values of approximately $10^{9}$ microbial cells per gram of soil, spread in something around 10 to 30 thousands distinct 'species'. This manuscript aim to demonstrate the advances promoted in the assessment of microbiomes in Brazilian soils, encompassing natural areas, such as mangroves and soils from the Northwest Caatinga; or soils used for agriculture, remarking the soils cultivated with sugarcane. Among the studies performed in natural areas, it is highlighted the advances achieved in mangrove soils, where the microbiome was described based on taxonomical units, and also in the functional features, found in this ecosystem under distinct levels of contamination. Concerning agricultural fields, soils cultivated with sugarcane have been addressed, supporting the detection of biogeographical patterns in the structuring of microbial communities, and being used for the description of microbial groups intimately interacting with plants.
\end{abstract}

Key words: biodiversity, microbial ecology, soil microbiology, culture-independent methods 


\section{INTRODUÇÃOO}

A ecologia microbiana se revolucionou com a utilização de metodologias de estudo independentes de cultivo, onde o acesso a grande maioria dos microrganismos fez-se possível, revelando uma diversidade muito maior do que a esperada. A complexidade das comunidades microbianas aumentam de acordo com a riqueza de espécies e a abundância das mesmas, o que elege o solo como o ambiente mais desafiador para o estudo da ecologia microbiana.

Dentro desta temática, muitos desafios podem ser traçados. No entanto, nem mesmo o primeiro deles, que consiste na descrição dos grupos que compõem as comunidades microbianas, está completamente decifrado nos solos brasileiros. Apesar do crescente número de estudos nestes ambientes, pouco se conhece sobre a extensão da diversidade e o papel funcional do microbioma presente nos solos de biomas brasileiros.

Parte deste desafio se dá em função das particularidades atribuídas a estes microbiomas, determinadas pelas peculiaridades dos ambientes encontrados em nosso pais, promovida pela variação climática e geológica, fatores determinantes nos processos de formação dos solos, e consequentemente as formas de vida (principalmente os vegetais) que compõem os biomas. Em todos estes ambientes, a comunidade microbiana responde pela base da cadeia trófica, suprindo nutricionalmente as plantas, e interferindo nos processos biogeoquímicos e geomorfológicos que ocorrem nos solos que os sustentam. Adicionalmente, temos em nosso território, solos muito distintos daqueles observados nas áreas onde as comunidades microbianas são mais amplamente estudadas, como em regiões de clima temperado. Outro fator que pode levar a ocorrência de processos seletivos únicos é a utilização de práticas agrícolas específicas para nosso clima e compatíveis com nossos tipos de solo, como por exemplo, o plantio direto.

Sobre este cenário heterogêneo e bastante dinâmico (devido às inovações promovidas pelo desenvolvimento metodológico de diferentes técnicas de análise microbiana), desafiador (pela complexidade), importante e promissor (pelas peculiaridades brasileiras) se desenvolve este documento, o qual visa relatar os avanços obtidos e os estudos em desenvolvimento com o objetivo de decifrar a estrutura e funcionalidade do microbioma de solos brasileiros. 


\section{REVISÃo BIBLIOGRÁFICA}

"The discovery of a microbial 'species' with potentially novel functions would be just as interesting as the

discovery of a star" Janet Jansson, Nature, 2013

\subsection{Biomas e solos brasileiros - características e peculiaridades}

O Brasil, em sua dimensão continental, hospeda diferentes biomas (Figura 1a), os quais juntos, correspondem a aproximadamente um terço das áreas naturais ainda intactas no planeta, tornando nossa nação um dos maiores reservatórios de biodiversidade terrestre (http://brazilbiodiversity.org/). O valor da biodiversidade dos biomas brasileiros é incalculável, principalmente devido ao potencial que possuem para o benefício do homem, do meio ambiente e do uso sustentável na agricultura e pecuária. Esta ampla biodiversidade e heterogeneidade de biomas distribuída em todo o território nacional abriga uma enormidade de ecossistemas distintos, os quais se apresentam sob condições ambientais particulares, e são sustentadas por diferentes tipos de solo.

Pode-se listar como biomas encontrados no território brasileiro a Amazônia, a Caatinga, o Cerrado, o Pantanal, a Mata Atlântica e o Pampa (Figura 1a). A Amazônia é a maior floresta tropical do mundo, ocupando uma área de. $5.500 .000 \mathrm{~km}^{2}$, divididos em 9 países (dos quais o Brasil hospeda a maior parte). Este bioma encontra-se em constante processo de desmatamento, principalmente causado pela exploração ilegal das áreas, usadas para extração de madeira, e para expansão das fronteiras agrícolas (Ministério do Meio Ambiente, 2002).

A Caatinga é o único bioma endêmico do Brasil, composta por uma área total de $850.000 \mathrm{~km}^{2}$ (cerca de $10 \%$ do território nacional) (GIULIETTI et al., 2006), distribuída ao longo do semi-árido do nordeste do Brasil, estendendo-se por vários estados brasileiros (SAMPAIO et al., 2000). Este bioma teve sua área diminuída nos últimos anos, principalmente devido ao processo de desertificação (Ministério do Meio Ambiente, 2002), o que torna indiscutível a necessidade de pesquisas voltadas para o conhecimento da microbiota associada a este ambiente, principalmente àquelas com enfoque nos microrganismos do solo, os quais sobrevivem sob condições de alto estresse hídrico, altas temperaturas e elevada incidência de radiação solar. 
O Cerrado ocupa uma região de aproximadamente $2.050 .000 \mathrm{~km}^{2}$ (distribuída em oito estados brasileiros), sendo considerado junto à caatinga, como os biomas de savanas tropicais. Devido a expansão agrícola intensificada nas últimas décadas, principalmente proporcionado por práticas de agricultura extensiva, este bioma vem sendo constantemente modificado quanto ao uso de suas áreas. O bioma de cerrado foi considerado não agricultável até a década de 60, sendo após este período observado um contínuo aumento na utilização dessas áreas para a produção agrícola nacional, o que torna o cerrado hoje o grande cinturão verde brasileiro (SOUZA et al., 2005). Esta revolução se fez possível devido a adoção de novas práticas de manejo, dentre as quais se destaca o uso da prática de gessagem, que reduz as quantidades de alumínio, que ocorre naturalmente nos solos desta região, juntamente com a calagem, que corrige o pH do solo, e o aumento da quantidade de matéria orgânica, promovido pela implementação da tecnologia de plantio direto (VITTI, 1984; MICHEREFF \& BARROS, 2001; NOVAIS et al., 2007).

O Pantanal é um bioma adjacente ao cerrado, caracterizado por períodos de alagamento de grande fração de suas terras em determinadas épocas do ano. Este bioma tem uma área de aproximadamente $250.000 \mathrm{~km}^{2}$, distribuídos entre Brasil, Paraguai e Bolívia (SILVA \& ABDON, 1998; JUNK et al., 2006). A variação no nível das águas nesta região, entre os períodos de cheia e vazante caracterizam este ambiente, o qual permanece ainda pouco explorado em relação a diversidade e funcionalidade microbiana, e ainda intocado no que diz respeito a exploração dos recursos naturais presentes nessas áreas. A atividade humana de destaque nas áreas do pantanal caracteriza-se pela pecuária extensiva (ABREU et al., 2006).

A Mata Atlântica é o bioma que hospeda maior diversidade de animais e plantas. Com isto, estudos sobre a estrutura e o funcionamento deste bioma são particularmente relevantes, considerando que as áreas restantes de vegetação nativa estão inseridas em uma matriz extremamente alterada pela ação antrópica (Ministério do Meio Ambiente, 2002; SANTOS et al., 2013). A grande diversidade biológica presente no solo deste bioma devese, entre outras razões, à distribuição Norte-Sul dessa floresta, à existência de consideráveis diferenças geológicas e de altitude, além das grandes transformações que a região sofreu em função das intensas mudanças climáticas pelas quais passou em distintos períodos geológicos (THOMAS et al., 1998). Dentro do bioma Mata Atlântica destaca-se a ocorrência do ecossistema de manguezais, amplamente distribuídos mundialmente, cobrindo cerca de 60 a 75\% da linha costeira tropical e subtropical. A importância deste ecossistema reside em 
sua elevada produtividade biológica, com alta diversidade de peixes, crustáceos, moluscos, aves, répteis e mamíferos (HOLGUIN et al., 2001; HOLGUIN et al., 2006).

O Pampa é um bioma de pradaria, localizado na região sul do Brasil, no Uruguai e Argentina (que abriga sua maior área). Este bioma apresenta características únicas devido a sua localização em região de clima temperado. A área do Pampa é de $750.000 \mathrm{~km}^{2}$, sendo aproximadamente $15 \%$ destes localizados em território nacional (Ministério do Meio Ambiente, 2002; ROESCH et al., 2009).
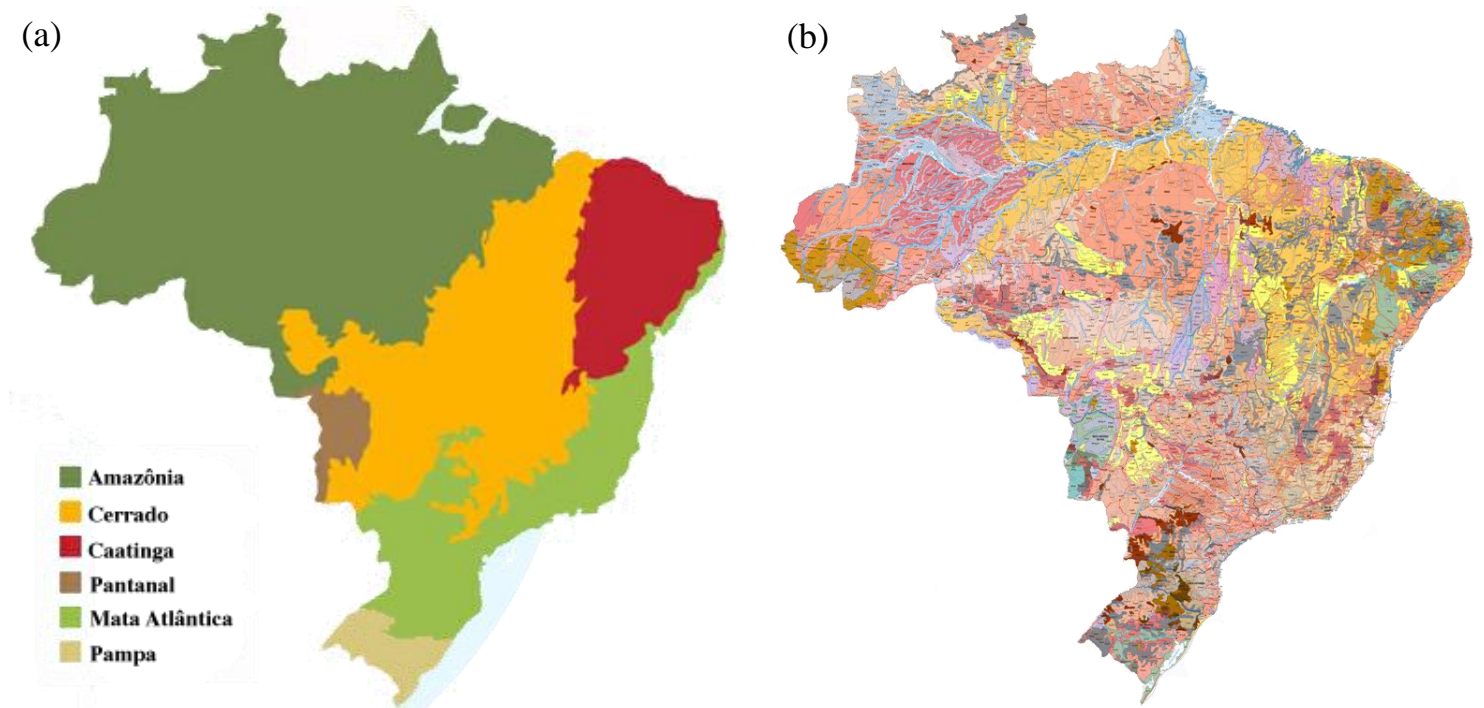

Figura 1. Mapa do território brasileiro destacando os biomas (a) e os tipos de solo (b) encontrados no território nacional. Devido ao grande número de tipo de solos, e ao enfoque deste manuscrito, os nomes do solos apresentados na figura $b$ foram suprimidos acima. Fontes: http://mapas.ibge.gov.br/tematicos/solos http://www.portalbrasil.net/brasil_solo.htm.

Vale ainda comentar que um dos biomas mais explorados atualmente no Brasil é de origem antrópica, e ocorre sobre os mais diferentes tipos de solo, de forma imersa aos demais biomas. O bioma agrícola, presente de forma fracionada e diferenciada ao longo de todo o território nacional, ocupa atualmente cerca de 70 milhões de ha, o que corresponde a aproximadamente 8,2\% do território nacional (IBGE - fevereiro de 2014). Este bioma originou-se como consequência das alterações em propriedades físicas, químicas e biológicas dos solos, sendo importante a inclusão do mesmo em aproximações que buscam entender o funcionamento a as características de solos brasileiros. Dessa forma, conhecer os fatores que modulam a diversidade microbiana neste sistema e sua influência no desenvolvimento das plantas, mostra-se como uma importante estratégia para levar a produção agrícola a um patamar de alta sustentabilidade. 
A classe de solos predominantes no Brasil são os Latossolos, amplamente distribuídos no território nacional, e sobre os quais se desenvolvem grande parte dos biomas brasileiros (Figura 1a). Este tipo de solo é extremamente abundante na região do Brasil Central e constitui as áreas de cerrado, onde se concentra a maior parte da produção agrícola brasileira (Figura 1b). São solos altamente intemperizados, com baixa CTC, distróficos, ácidos, bem drenados e basicamente constituídos de minerais do tipo 1:1 (caulinita, por exemplo) e óxidos e hidróxidos de ferro e alumínio, sendo, portanto, de baixa fertilidade natural (KER, 1997). Apresentam propriedades físicas, como a microagregação, que favorece a estruturação do solo, facilitando a percolação e a retenção da água, conferindolhe um caráter friável quando úmido, permitindo a penetração do sistema radicular das culturas. Portanto, estes são solos altamente responsivos ao manejo voltado para a construção de sua fertilidade, correções, adubação e mecanização. Além dos latossolos, observa-se ainda a cobertura de grandes áreas por solos classificados como Argissolos (Figura 1b), o qual tem como principal característica a presença de horizonte diagnóstico B textural, oriundo de acúmulo subsuperficial de argila, com profundidade e drenagem variáveis (VIDAL-TORRADO et al., 2005).

A relação entre o tipo de solo e o ecossistema que o mesmo sustenta pode ser visualizada facilmente em algumas ocasiões. Os solos hidromórficos Cambissolos, Neossolos Flúvicos e Gleissolos são típicos do pantanal, onde a flutuação das águas e a restrição de drenagem resultam num sistema altamente sujeito a períodos de anaerobiose, acúmulo de sedimentos aluviais e coloração acinzentada (BUOL, 1997; LEPSCH, 2011). Este mesmo tipo de observação também é possível para os Organossolos, os quais são predominantemente formados em várzeas e em áreas de litoral sob condição de inundação fluvial, como por exemplo, nos manguezais (um ecossistema do bioma Mata Atlântica) (OTERO et al., 2009; FERREIRA et al., 2010). Estes solos, por serem comumente ricos em matéria orgânica e anaeróbios, possuem um maior potencial de seleção para sua ocupação, apresentando portanto, menor diversidade de plantas.

Um fator ambiental também importante, tanto na distribuição dos biomas, como dos solos encontrados no Brasil, está relacionado com o clima, dentro do qual são determinantes a temperatura média e o regime de pluviosidade da região. Na maior parte do território nacional, dominada por regiões tropicais e subtropicais com altas temperaturas, umidade e boa drenagem, ocorre o favorecimento do processo de intemperismo (BUOL, 1997; LEPSCH, 2011). Na região Nordeste, devido a escassez de água, este processo é mais lento, o que leva a predominante formação de solos pouco intemperizados como os Neossolos, ou 
ainda solos com minerais de argila 2:1 (esmectitas, por exemplo), como os Vertissolos (BUOL, 1997; KAMPF et al., 2000; LEPSCH, 2011). A formação de argila 2:1 também ocorre em regiões de clima temperado, mais especificamente no Sul do Brasil, onde predomina a formação de montmorilonita, juntamente com uma lenta decomposição de material orgânico, dando origem a solos de alta CTC e alta saturação por bases (V\%>50), como os Chernossolos, Luvissolos e Cambissolos (BUOL, 1997; KAMPF et al., 2000; LEPSCH, 2011).

\subsection{Biologia do solo}

Parte essencial do sistema solo, os organismos que o habitam possuem funções de grande importância, sendo estas tidas atualmente como mais essenciais do que previamente imaginado. Pode-se enumerar dentre as mais diferentes funções atribuídas a estes, aquelas mais amplamente conhecidas, como a degradação de compostos orgânicos, e conseguinte ciclagem de nutrientes (GILLER, 1996; MIRANSARI, 2013; graham et al., 2014), e aquelas mais específicas, como a fixação biológica de nitrogênio (RAYMOND et al., 2004; BALDANI et al., 1997), ou o auxílio às plantas na absorção de nutrientes (MIRANSARI, 2013; CHAGNON et al., 2013).

No entanto, antes de comentar mais especificamente sobre estas funções, faz-se necessário descrever os grupos de organismos que fazem parte da fração viva do solo, uma vez que estes são amplamente diversos (NACKE et al., in press; BRADY \& WEIL, 2013), englobando desde organismos procarióticos, como bactérias e arquéias (que compreendem dois dos três domínios da vida); e organismos eucarióticos, onde se destacam os fungos. Também estão presentes os insetos, os nematóides, os protozoários, as algas, os oligoquetas (minhocas); e até mesmo os vírus, que tem seu papel ainda muito pouco explorado neste ambiente (BRADY \& WEIL, 2013).

As diferentes classes de organismos são por vezes estudadas separadamente, e seletivamente chamadas de fauna do solo (organismos maiores), e microfauna do solo (organismos menores) (GILLER, 1996). Dentre as funções atribuídas aos componentes da fauna do solo se destacam a degradação inicial de componentes orgânicos (incorporação e trituração), e a atuação na estruturação dos solos (GILLER, 1996; SITTERS et al., in press), sendo estes organismos também usados para se correlacionar a qualidade do solo com a presença ou abundância dos mesmos (CAMARA et al., 2012; BARTZ et al., 2013). Já em relação aos organismos de menor tamanho, as funções são mais numerosas, principalmente devido a maior diversidade metabólica encontrada em bactérias, fungos e arquéias quando 
comparados aos demais organismos componentes da biologia do solo. Esta maior diversidade está diretamente relacionada a variabilidade genética e metabólica presente em tais organismos, o que se deve a origem e evolução dos mesmos, tornando-os o componente principal do metabolismo do sistema solo. Esta essencialidade se dá pelas funções desempenhadas de forma exclusiva pelos microrganismos, e por sua dominância numérica sobre os demais (GILLER, 1996). Assim sendo, pode-se justificar a essencialidade do conhecimento sobre a organização dessas comunidades e seu funcionamento para o completo entendimento do sistema solo.

Ainda dentro de linhas gerais, pode-se enumerar dois processos microbianos tidos como os maiores exemplos do benefício dos microrganismos no desenvolvimento vegetal: a fixação biológica do nitrogênio e as micorrizas (MOREIRA \& SIQUEIRA, 2002; RAYMOND et al., 2004; MOREIRA et al., 2007; CHAGNON et al., 2013). Essas interações são amplamente estudadas, sendo muitos detalhes que regem estes tipos de simbioses são descritos na literatura. No entanto, a diversidade microbiana presente nos solos é enorme, e muitos outros processos podem ocorrer em caráter essencial na manutenção deste sistema, influenciando no desenvolvimento das plantas. Assim sendo, o grande desafio reside em descrever esses processos, e manipulá-los de forma otimizada, obtendo assim maior eficiência energética na produção vegetal. A visão de uma vasta diversidade microbiana é ainda recente, uma vez que esta foi apenas obtida com a utilização de métodos independentes de cultivo. Assim sendo, novas tecnologias tem nos permitido acessar e entender com maior profundidade a complexidade biológica do sistema solo.

\subsection{Diversidade microbiana em solos de biomas brasileiros}

A fração viva do solo é atualmente tida como essencial para a funcionalidade dos solos, sendo a esta atribuídos muitos processos que regem a manutenção e a funcionalidade dos solos. No entanto, o desempenho de funções similares em solos distintos pode ser tanto realizado pelo mesmo grupo de organismos, ou por organismos distintos, o que leva a necessidade da compreensão da composição e do funcionamento metabólico do microbioma dos solos que sustentam os biomas brasileiros.

Considerando as áreas naturais, temos ainda pouco conhecimento sobre a microbiologia dos principais biomas brasileiros, principalmente devido à extensão do território nacional, o que gera a necessidade de grandes esforços amostrais, o que por vezes é limitado ao acesso restrito a áreas mais remotas. 
Poucos estudos acessaram os microrganismos existentes na caatinga, sendo um deles desenvolvido por Gorlach-Lira Coutinho (2007), que estudaram a dinâmica populacional de bactérias presentes na rizosfera de Aristida adscensionis (Poaceae), onde foi observado uma prevalência de bactérias mesofílicas heterotróficas formadoras de esporos e actinobactérias neste ambiente, sugerindo o desenvolvimento de adaptações especiais às condições ambientais pelos microrganismos, da mesma forma que é observado para plantas e animais. Mais recentemente, Kavamura et al. (2013) relataram a predominância do efeito da rizosfera de plantas da caatinga, como o mandacaru, na época das chuvas, sugerindo que as alterações de determinados grupos microbianos se dá de acordo com variações no ciclo de vida das plantas que habitam essas regiões.

Dentro do bioma Amazônia, o tema em que se tem maior número de estudos científicos é o efeito do desmatamento sobre a diversidade e a estrutura das comunidades microbianas do solo e associadas às plantas. Neste sentido, um trabalho recente mostrou a homogeneização da microbiota em áreas de floresta convertidas para o uso como pastagem, indicando que a remoção da floreta diminui a beta diversidade ${ }^{1}$ deste bioma (RODRIGUES et al., 2013). Este efeito se dá possivelmente devido a desestruturação física natural do solo, o que resulta em uma maior exposição de nutrientes e consequentemente nichos a serem ocupados pela microbiota.

Em relação à Mata Atlântica, os estudos são escassos sobre a microbiologia do solo. Santos et al. (2014) demonstraram a alta variabilidade espacial na composição da comunidade microbiana dentro de uma mesma área amostral. Neste ambiente, destaca-se a descrição das comunidades bacterianas da filosfera das plantas deste bioma, revelando a grande diversidade microbiana ainda não conhecida e que ocorre de maneira específica para cada espécie vegetal habitante deste sistema (LAMBAIS et al. 2006).

Dentro da Mata Atlântica, diversos ecossistemas podem ocorrer, dentre os quais estão os manguezais, cujas comunidades microbianas vêrm sendo amplamente descritas em estudos que revelam sua taxonomia (DIAS et al., 2010; DIAS et al., 2011; FASANELLA et al., 2012; SANTOS et al., 2011a) e funcionalidade (GOMES et al., 2008; ANDREOTE et al., 2012; DIAS et al., 2012; VARON-LOPEZ et al., 2014). Vários destes trabalhos indicam a ocorrência de grupos de genes e de organismos possivelmente endêmicos, o que pode ser resultado de uma combinação particular de fatores de seleção que ocorrem neste ambiente,

\footnotetext{
${ }^{1}$ Beta diversidade: diversidade entre locais distintos, revela a heterogeneidade na estrutura das comunidades.
} 
o qual se caracteriza como um ecótone, e localiza-se como um ecossistema de ligação entre o ambiente terrestre e marinho.

Em relação aos biomas agrícolas, o principal foco de estudo é o efeito na mudança do uso do solo sobre as comunidades microbianas e as possibilidades de uso dos mesmos para a obtenção de maior produtividade agrícola. Em relação a mudança do uso do solo, diversos estudos tem utilizados áreas de expansão agrícola como modelo (KAHINDI et al., 1997; JESUS et al., 2009). Um dos exemplos deste tipo de estudo acessou a comunidade bacteriana em solos de áreas naturais do Pampa, e comparou esta comunidade com as encontradas no mesmo solo diferente tipo de uso (LUPATINI et al., 2013). Os autores verificaram que a mudança no uso da terra levou a alterações taxonômicas, mas não funcionais nos solos estudados. Rodrigues et al (2013) revelaram a homogeneização que ocorre na microbiota dos solos quando seu uso é convertido de uma área nativa para a produção de pastagem. Mendes et al. (in press) revelaram o efeito determinístico da rizosfera de soja sobre a comunidade microbiana de um solo da Amazônia. Estes estudos sugerem que o cultivo das plantas acarreta na seleção de determinados grupos microbianos, o que explica a homogeneização dos solos, e a consequente redução da beta diversidade (características dos biomas naturais) em áreas de cultivo agrícola.

\subsection{O acesso a diversidade microbiana - métodos independentes de cultivo}

A diversidade das formas de vida no solo é bastante vasta, sendo esta regida pela grande heterogeneidade deste ambiente. Apesar de o solo ter aparência homogênea, este ambiente é composto de uma grande diversidade de nichos, sendo cada um deles compostos por uma distinta combinação de fatores ambientais, tornando este ambiente altamente heterogêneo do ponto de vista de organismos de tamanho reduzido. Somada a esta heterogeneidade espacial, ocorre a heterogeneidade temporal, como por exemplo flutuações na temperatura, que ocorrem em um solo de cerrado ao longo de um dia, ou em um solo do Pampa ao longo do ano. As flutuações na temperatura acarretam alterações na atmosfera do solo e aos valores de $\mathrm{pH}$ do mesmo, influenciando diretamente os grupos microbianos que compõem as comunidades microbianas dos solos (FIERER et al., 2007). Com este cenário, gera-se a condição ambiental perfeita para que, em longo prazo, mantenha-se uma enorme diversidade de formas de vida nesses ambientes, sendo frações desta diversidade total beneficiados a cada milímetro e a cada minuto dentro do solo em que se encontram.

Uma vez que a diversidade é enorme, e a adaptação dos diferentes organismos se dá em condições distintas um dos outros, pode-se imaginar que apenas uma minoria pode ser 
facilmente cultivada em condições de laboratório (STALEY \& KONOPKA, 1985; AMANN et al., 1995). Se considerarmos uma placa de cultivo na qual as condições nutricionais e físicas são constantes e homogêneas, podemos facilmente observar a contradição em representar as comunidades microbianas do solo por meio de colônias obtidas em meios de cultivo (AMANN et al., 1995). Estudos recentes, focados na descrição de grupos bacterianos presentes no solo, porém de difícil cultivo, tem revelado a estratégia evolutiva desses organismos, como a organização genômica compacta, o que leva a uma maior eficiência na multiplicação celular, porém ligada a uma grande dependência da interação com demais organismos para completar seu ciclo vital (VAN SLUYS et al., 2002; DINI-ANDREOTE et al., 2012). Assim sendo, não apenas as condições de cultivo, mas nossa visão antrópica de obter os componentes das comunidades microbianas dos solos de forma isolada, dificulta $\mathrm{o}$ uso de métodos dependentes de cultivo para a o estudo e entendimento de forma mais robusta dessas comunidades.

Neste sentido, a aplicação das técnicas chamadas de independentes de cultivo, baseadas na detecção e análise da diversidade de ácidos nucléicos (i.e. DNA ou RNA) em amostras ambientais, é fundamental nos estudos de diversidade microbiana dos solos, permitindo uma análise mais fiel da estrutura das comunidades acessadas (RANJARD et al., 2000; ANDREOTE et al., 2009). Dentro destas metodologias de análise, existem alguns subgrupos, como as análises baseadas em um gene (baseadas na amplificação do gene alvo por PCR), ou análises que contemplam todos os genes de maneira conjunta (metagenômica e metatranscriptômica). Estas análises passam atualmente por um intenso processo de automatização, o que é possível devido a evolução nas metodologias e na redução no custo do sequenciamento de DNA (Box 1). Isto faz com que seja possível trabalhar com um maior número de amostras, e acessar uma enorme quantidade de indivíduos em cada uma delas, trazendo grande robustez às inferências realizadas.

Ecologicamente, essas análises são essenciais, pois permitem que dentro de comunidades compostas por um grande número de grupos taxonômicos, tenha-se a amostragem de um grande número de indivíduos, gerando assim a cobertura ecológica necessária para se inferir de forma concreta sobre a composição e a resposta de tais comunidades frente a diferentes condições ambientais estudadas. $\mathrm{O}$ exemplo pioneiro neste tipo de análise em solos enumerou as diferenças encontradas na composição do microbioma de solos de diferentes países por meio da análise de uma grande número de sequências do gene 16S RNAr (ROESCH et al., 2007). 
A maioria dos estudos baseados em um gene, se referem a taxonomia dos grupos microbianos, o que é comumente realizado com base em sequências dos operons ribossomais (gene 16S RNAr para bactérias e arquéias, e gene 18S RNAr ou regiões ITS para fungos) (HEUER et al., 1997; ANDERSON et al., 2003). A amplificação desses genes a partir de DNA ou cDNA (convertido a partir de RNA) obtidos de amostras de solo, dá suporte a análises posteriores, gerando informações sobre a estrutura das comunidades microbianas alvos de estudo (métodos de fingerprinting), a abundância (quantificação), ou a composição taxonômica dos organismos presentes nessas comunidades (métodos de sequenciamento) (ANDREOTE et al., 2009).

No entanto, para obter informações correlacionadas com os papéis desempenhados por grupos microbianos nos solos, outros genes vêm sendo utilizados em estudos de microbiologia molecular, com destaque para os genes relacionados a etapas específicas dentro dos ciclos biogeoquímicos. Dentre estes, os genes mais utilizados são aqueles relacionados a ciclagem de nitrogênio (nifH - fixação biológica de nitrogênio; amoA nitrificação; nirK, nosZ - desnitrificação), enxofre ( $\operatorname{sr} B$ - redução de sulfato; aprA redução e oxidação do enxofre) ou carbono ( $m c r A$ - metanogênese, $p m o A$ - metanotrofia) (HANSON \& HANSON, 1996; HENCKEL et al., 2000; GEETS et al., 2006; LEININGER et al., 2006; HENRY et al, 2006; BERNHARD et al., 2007). Outras funções podem também ser estudadas, sendo o único fator limitante, a fiel relação da presença de um gene com a observação do fenótipo desejado nos organismos que hospedam a sequência de DNA no ambiente.

Considerando as análises mais amplas, primeiramente devemos ponderar a metagenômica, a qual surge como uma grande alternativa para descrever a diversidade microbiana do solo, contemplando em uma mesma análise as informações taxonômicas e funcionais presentes na comunidade. Este termo (metagenoma) foi cunhado em 1998 para representar os genomas da microbiota total encontrada em uma comunidade (HANDELSMAN et al., 1998). Esta estratégia oferece uma alternativa para a exploração do potencial metabólico de microrganismos que não são recuperados por métodos baseados em cultivo. O método consistiu-se inicialmente na clonagem de fragmentos grandes de DNA (40 a $100 \mathrm{~kb}$ ), obtidos a partir de amostras ambientais, em vetores do tipo BAC (Bacterial Artificial Chromosome) ou cosmídeos, e a análise das bibliotecas resultantes em busca de uma nova expressão fenotípica na linhagem hospedeira de Escherichia coli (HANDELSMAN et al., 1998). 
No entanto, com o desenvolvimento das tecnologias de sequenciamento massivo (Box1), alterações surgiram neste conceito, sendo hoje possível acessar amplamente a informação genética contida em amostras de solo excluindo-se a etapa de clonagem. Este tipo de análise é bastante interessante pela possibilidade de descrever de maneira representativa os genes funcionais e taxonômicos conjuntamente, colocando estes enfoques em uma mesma análise, o que permite a melhor inferência sobre a relação entre a estrutura e a funcionalidade microbiana dos solos.

O primeiro trabalho que utilizou este tipo de metodologia conseguiu reconstruir genomas bacterianos por meio do sequenciamento do DNA diretamente extraído de amostras de uma mina ácida, onde poucos grupos microbianos compõem o microbioma (TYSON et al., 2004). Outro exemplo desta aplicação buscou descrever a diversidade filogenética e funcional da comunidade microbiana presente em amostras de gelo glacial (SIMON et al., 2009), onde os resultados demonstraram parte do metabolismo microbiano neste ambiente, com destaque para a presença de genes de adaptação à psicrofilia.

Em solos, este tipo de análise vem sendo amplamente utilizada, com um dos primeiros trabalhos realizados para a comparação da microbiota, suas funcionalidades e potencial biotecnológico com base no sequenciamento do DNA diretamente retirado do solo (TRINGE et al., 2005). Mais recentemente, este tipo de análise vem sendo empregado na descrição de novas enzimas e na identificação da resposta da microbiota do solo a eventos de contaminação (SANGWAN et al., 2012; FIERER et al., 2013).

Em relação aos biomas brasileiros, o microbioma presente nos solos de manguezais foi descrito por este tipo de análise (ANDREOTE et al., 2012), onde se nomeou os principais organismos componentes desta comunidade, e se descreveu as principais transformações metabólicas envolvidas nos ciclos biogeoquímicos do nitrogênio, carbono e enxofre (ver Sessão II). Outros biomas brasileiros tem sido explorados com base neste tipo de análise, sendo estes sumarizados em um artigo recentemente publicado por Pylro et al. (2014).

Vale a pena comentar sobre as quantidades variadas de sequências de DNA obtidas em análises metagenômicas, as quais apresentam baixas ou nenhuma similaridade com aquelas presentes em bancos de dados. Isto demonstra o potencial desta análise em descrever novos genes, ou novos arranjos genômicos, distintos daqueles já conhecidos na literatura. Este grupo de sequências foi inicialmente tratado como algo de menor importância no início dos estudos metagenômicos, mas tem recentemente atraído bastante atenção, principalmente no intuito de desvendar a possível função contida nessas sequências de DNA (TOBARTOSSE et al., 2013). 
Na mesma linha de análise, existe a possibilidade de se basear o sequenciamento na porção funcional do microbioma, utilizando moléculas de RNA como molde, em um tipo de estudo denominado de metatranscriptômica. Neste contexto, a metatranscriptômica aparece como uma metodologia poderosa para determinar padrões de expressão gênica de comunidades microbianas (PORETSKY et al., 2005; FRIAS-LOPEZ et al., 2008). Em contraste com a metagenômica, que fornece uma análise sobre a estrutura genética da comunidade, a metatranscriptômica identifica quais destes genes estão sendo ativamente transcritos no ambiente avaliado (GILBERT et al., 2008; PORETSKY et al., 2010).

Analisando amostras de comunidades microbianas marinhas, Gilbert et al. (2008) descreveram a alta eficiência desta metodologia, e destacaram a possibilidade de detectar genes pertencentes a muitas famílias nunca anteriormente descritas em análises baseadas em moléculas de DNA. Em solos, alguns estudos utilizaram esta metodologia para a descrição de genes eucarióticos expressos sob diversas condições, como em solos de floresta (DAMON et al., 2012), ou na determinação de genes relacionados a resistência a metais pesados (LEHEMBRE et al., 2013). O foco inicial em eucariotos se deu devido ao método de separação do RNAm do RNA total. Uma vez que a grande maioria do RNA obtido é de origem ribossomal, a separação mais eficiente é por purificação em colunas poliT, onde os RNAm que possuem cauda poliA ficam retidos. No entanto, estes representam apenas a fração eucariótica das comunidades. $\mathrm{O}$ acesso aos transcritos de bactérias e arquéias se dá por meio do sequenciamento do RNA total, ou por meio de separação do RNAm desses organismos com o uso de hibridização por sondas para remoção do RNAr, como descrito por He et al. (2010). Resta ainda a possibilidade de sequenciar todo o RNA extraído, usando assim as sequências de genes ribossomais para uma análise taxonômica dos grupos com metabolismo ativo na amostra, ao passo que as sequências de RNAm, mesmo que em menor número, são utilizadas para a análise das funções ativas na amostra. Isto foi feito em um dos primeiros trabalhos de metatranscriptômica em solos, onde se realizou uma análise conjunta da taxonomia e funcionalidade do microbioma de solos de uma área de preservação na Alemanha (URICH et al., 2008). Uma revisão recente enumera os estudos realizados com base nesta técnica, e comenta sobre as variáveis presentes nos estudos de metatranscriptômica de solo (CARVALHAIS et al., 2012). Esta ferramenta tem grande potencial de uso na descrição da atividade microbiana encontrada em diferentes solos brasileiros, levando a descrição dos grupos ativos nos diferentes ambientes e sob distintas condições de conservação e uso do solo. 
É importante destacar que não existe uma metodologia perfeita, a qual forneça todo tipo de informação sobre as comunidades microbianas do solo, mas existem metodologias adequadas para responder as diferentes questões que são geradas ao longo do desenvolvimento dos trabalhos focados no microbioma dos solos. Numa análise comparativa, é possível verificar a vantagem de metodologias baseadas em PCR devido ao melhor detalhamento que a mesma proporciona no acesso ao grupo alvo (maior cobertura de análise, por exemplo), enquanto que as 'ômicas' geram dados mais completos sobre taxonomia e funções microbianas, porém sob uma cobertura menor da comunidade (normalmente representando principalmente os grupos mais abundantes). Ainda cabem nesta comparação, o custo para a obtenção dos dados e a análises dos mesmos, que requerem habilidades especificas e na grande maioria das vezes recursos computacionais de grande capacidade de processamento e tempo de análise.

Destaca-se neste item, uma revisão publicada pelo candidato, no ano de 2009, que comenta sobre as análises independentes de cultivo para o estudo de comunidades microbianas:

Andreote, FD; Azevedo, JL; Araújo, WL. Assessing the diversity of bacterial communities associated with plants. Brazilian Journal of Microbiology, v. 40, p. 417-432, 2009. (Doc. VII-1.16) 


\section{Box 1. Evolução dos métodos e do custo do sequenciamento de ácidos nucléicos.}

O sequenciamento de DNA é a base da evolução das metodologias atuais empregadas no estudo de comunidades microbianas. Pode-se dizer que anteriormente ao surgimento destas, a microbiologia viveu sua fase mais estagnada, sendo os conhecimentos morfológicos e bioquímicos de células microbianas já não mais capazes de atribuir características diferencias aos organismos cultivados, os quais compunham a base dos estudos de caracterização e de ecologia microbiana.

As metodologias capazes de gerar as sequências do material genético têm evoluído de forma acentuada nos últimos anos. Se inicialmente os estudos baseados em sequências de DNA eram realizados por poucos grupos de pesquisa, devido ao seu elevado custo e a necessidade de equipamentos especiais, atualmente estes estão amplamente disseminados entre os pesquisadores, principalmente para os que atuam nas áreas de ecologia microbiana e microbiologia ambiental.

O método de Sanger, o primeiro a ser descrito com esta finalidade, no ano de 1977, foi usado para sequenciar genes, fragmentos de DNA genômicos e até mesmo genomas pequenos, como o bacteriófago X174 (5.386 pb) (Sanger et al., 1977) e a bactéria Haemophilus influenzae (1.8 Mb) (Fleischmann et al., 1995).

Esta metodologia passou por diversas adaptações as quais ampliaram a escala de trabalho, sendo a maior delas a automatização do sistema por sequenciamento em capilares, a qual possibilitou seu uso no estudo de genomas maiores, sendo o maior deles o sequenciamento do genoma humano, o qual foi resultado de mais de uma década de trabalho, sendo finalmente anunciado no ano de 2001 (Venter et al., 2001).

No entanto, devido a necessidade de se clonar os fragmentos anteriormente ao seu sequenciamento, e a capacidade de gerar poucas sequências por escala de tempo, tal metodologia possuía um elevado custo e baixo rendimento, principalmente quando empregada no estudo de genomas maiores, ou mesmo àqueles que demandavam um maior número de sequencias por organismos e/ou ambiente de forma concomitante.

O esperado avanço surgiu com o desenvolvimento das tecnologias nomeadas de sequenciadores de segunda geração (next generation sequencing) ou NGS, as quais não necessitam da clonagem prévia do material a ser sequenciado, e geram quantidades muito maiores de informação por tempo de processamento. Entre tais tecnologias estão aquelas desenvolvidas pelas empresas Roche (pirosequenciamento 454), Life Technologies (Solid, IonTorrent) e Illumina (HisScan, HiSeq2000), dentre outras. Tais tecnologias são concorrentes no mercados, e têm levado ao amplo acesso da informação genética de organismos específicos, sejam estes encontrados em cultura pura, ou em comunidades ambientais complexas. A grande vantagem que acompanha o montante de dados gerado é o custo do sequenciamento, o qual reduziu drasticamente ao longo dos últimos anos, obedecendo a chamada Lei de Moore, inicialmente usada para descrever o avanço na capacidade de análise de dados computacionais, e atualmente usada para predizer o avanço na capacidade de se gerar informações genéticas a partir de amostras biológicas. (Figura B1).

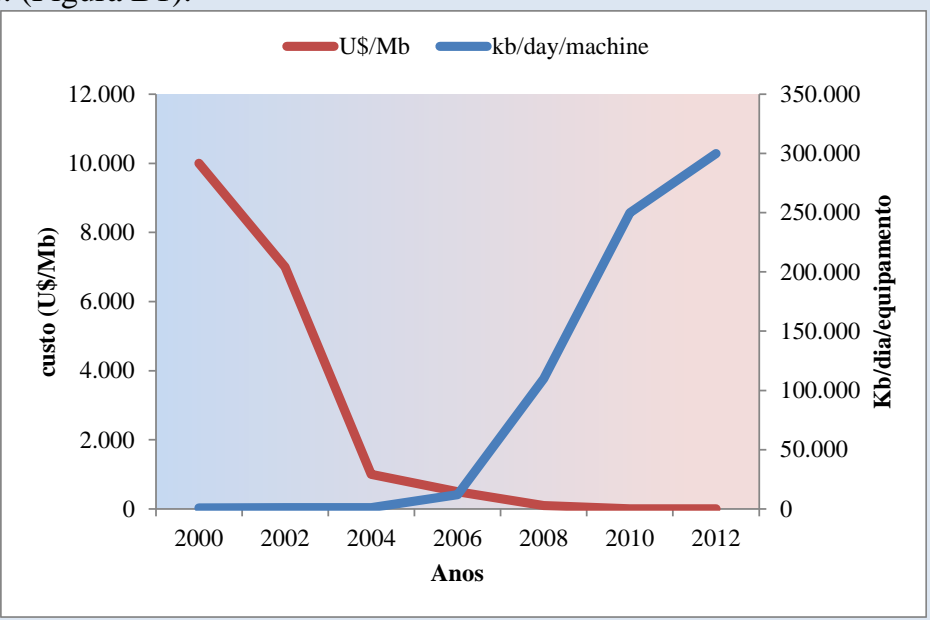

Figura B1. Evolução do custo e da quantidade de dados gerados ao longo do desenvolvimento das metodologias de sequenciamento de DNA.

Sanger et al. (1977). Nucleotide sequence of bacteriophage phi X174 DNA. Nature 265: 687-695.

Fleischmann et al. (1995). Whole-genome random sequencing and assembly of Haemophilus influenzae Rd. Science 269: 496-512.

Venter et al. (2001). The Sequence of the Human Genome. Science 291: 1304-1351. 


\subsection{O termo microbioma}

O termo microbioma foi usado pela primeira vez por Joshua Lederberg, que o definiu como 'a comunidade ecológica de microrganismos comensalistas, simbiontes ou patogênicos, que literalmente ocupam o espaço de nosso corpo', se referindo nesta ocasião ao microbioma humano (LEDERBERG \& MCCRAY, 2001). Já em 2002, esta definição foi simplificada como 'microrganismos associados aos humanos' (RELMAN, 2002; TURNBAUGH et al., 2007, The Human Microbiome Project Consortium, 2012). Sabe-se hoje que o Microbioma Humano é composto por 10 vezes mais células microbianas do que o número de células humanas que compõem nosso corpo. Em número de genes, esta proporção é ainda maior, com 1 gene humano para cada 100 genes microbianos. Esta enorme diversidade de organismos e funções tem sido referenciada como sendo um órgão vivo, do qual dependemos para exercer diversas funções vitais, como por exemplo a regulação de diversos processos fisiológicos, o auxílio na digestão e absorção de nutrientes, a resistência a patógenos, entre outras (LEY et al., 2006; The Human Microbiome Project Consortium, 2012, DIJIKENG et al., 2011). Alguns dos exemplos da funcionalidade deste 'órgão microbiano' revelam que $36 \%$ das moléculas encontradas em nosso sangue é produzida por microrganismos associados ao nosso trato digestivo (NICHOLSON et al., 2012). Outro trabalho mostra a resposta fenotípica de camundongos inoculados com microbiomas oriundos de indivíduos obesos ou magros, onde se observou o fenótipo do organismos doador em receptores desprovidos de microbiota própria (TURNBAUGH et al., 2006).

Atualmente este termo é usado para descrever o conjunto de microrganismos que hospedam um determinado hospedeiro, ou que ocupam conjuntamente um ambiente (BOON et al., 2014; OFEK et al., in press). Boon et al. (2014) propõem que a melhor definição de microbioma seria aquela relacionada ao conjunto de genes encontrados de maneira associada aos organismos que colonizam um determinado ambiente. Esta definição é estruturada de forma a eliminar as variações causadas quando apenas inferências taxonômicas são feitas para caracterizar os microbiomas. Apesar da informação taxonômica ser a forma mais utilizada para este tipo de estudo, sabe-se que comunidades microbianas complexas apresentam altas taxas de transferência de material genético, o que faz com que as funções ecológicas e metabólicas possam ser exercidas por organismos distintos (i.e. redundância metabólica), tornando a descrição taxonômica dependente de uma associação com sua descrição funcional. Assim sendo, estes autores sugerem que a melhor forma de descrever um microbioma está na descrição robusta dos genes que o compõe, e por conseguinte, das 
funções que podem ser desempenhadas pela microbiota associada a determinado hospedeiro ou ambiente.

Dentro desta maior abrangência, e contrastante com os exemplos de estudo do microbioma humano, apresenta-se o estudo do microbioma dos solos, amplamente desafiadores, principalmente em função da grande diversidade nas formas de vida contidas neste ambiente e a heterogeneidade dos mesmos. A melhor compreensão deste componente apresenta-se como uma das bases para as futuras revoluções na agricultura e uso do solo. Um exemplo desta potencialidade está na atribuição da característica supressiva de solos a seus respectivos microbiomas (WELLER et al., 2002; MENDES et al., 2011), sendo os microrganismos os agentes da inibição da ocorrência de doenças mesmo na presença dos patógenos (VAN ELSAS et al., 2012). Apesar dos enormes avanços obtidos por meio da inovação tecnológica relacionada ao acesso da informação microbiológica, ainda não existe um método robusto o bastante para acessar de forma completa, o microbioma presente em um solo (VOGEL et al., 2009). Soma-se a esta grande diversidade do sistema solo a necessidade de metodologias que indiquem de forma sólida as alterações que ocorrem na escala temporal, o que ainda é bastante limitado devido ao custo de análise e cobertura amostral desejada.

Sabe-se que os solos apresentam uma estruturação das comunidades microbianas com determinada similaridade se analisados em um elevado nível taxonômico (TRINGE et al., 2005; JANSSEN, 2006; PHILIPPOT et al., 2013), ou seja, composta de um core microbiano encontrado na grande maioria dos solos. Este core é mais facilmente definido para a comunidade bacteriana do solo, composto principalmente pelos filos Acidobacteria, Actinobacteria, Proteobacteria, Verrucomicrobia, Bacteroidetes, Firmicutes e Planctomycetes (JANSSEN, 2006). Este core é relativamente estável dentro do conceito taxonômico da comunidade microbiana, mas pode ser distinto em relação às funções desempenhadas pelos organismos que os compõem. Isto se dá devido a alta taxa de transferência gênica em ambientes complexos, como descrito na revisão publicada por DiniAndreote et al. (2012), onde os autores indicam que a organização genômica de bactérias é resultado da interação das mesmas com o ambiente. Assim sendo, organismos taxonomicamente similares, podem ter funções distintas, de acordo com o ambiente onde se encontra e desenvolve. Observa-se portanto, que o conceito de microbioma deve ser melhor aplicado aos solos, o que é proposto pela iniciativa chamada de Terragenoma (http://www.terragenome.org/) (VOGEL et al. 2009), a qual tem como objetivos organizar as informações geradas sobre o microbioma dos solos, e realizar a completa descrição do 
material genético microbiano contido em um grama de solo. Com isto, espera-se estabelecer parâmetros e entender melhor as interações microbianas que regem este ecossistema.

Em relação aos solos brasileiros, este tipo de estudo se faz necessário, uma vez que é sobre tais solos e seus respectivos microbiomas que se sustentam biomas de grande biodiversidade, ou mesmo áreas de cultivo agrícola com elevada produtividade e importância econômica. Pode-se ainda extrapolar o conceito de microbioma, considerandoo não apenas como o conjunto de organismos presentes em uma área distinta, mas associados aos diferentes solos sobre os quais se desenvolvem a mesma cultura agrícola, ou apresentam a mesma paisagem, inserindo assim o conceito de biogeografia na definição de microbioma (DOLAN, 2006; FIERER et al., 2006; MARTINY et al., 2006).

No Brasil, uma iniciativa originou o grupo denominado Brazilian Microbiome Project (BMP) (http://www.brmicrobiome.org/), o qual visa descrever o microbioma associado ao diversos ambientes brasileiros. Este grupo publicou seu primeiro trabalho, onde é apresentada uma revisão detalhada dos estudos desenvolvidos com esta finalidade nos mais diferentes ambientes brasileiros (PYLRO et al., 2014), dentre os quais destacam-se os solos, explorados em diferentes áreas do território nacional. Os membros componentes desta iniciativa estão atuando de forma colaborativa com uma iniciativa mundial do chamada Earth Microbiome (http://www.earthmicrobiome.org/), a qual deve facilitar a inserção dos dados sobre os biomas brasileiros em um cenário mundial, onde estes poderão ser comparados a outros ambientes, dando base à comparação e elucidação da elevada biodiversidade brasileira, também no tocante as comunidades microbianas.

Dois trabalhos publicados pelo candidato se relacionam com a temática microbioma e seus componentes, sendo um comentário sobre organização de genomas, publicado em 2012, e um artigo do grupo Brazilian Microbiome Project, publicado em 2014:

Dini-Andreote, F; Andreote, FD; Araújo, WL; Trevors, JT; van Elsas, JD. Bacterial genomes: habitat specificity and uncharted organisms. Microbial Ecology, v. 64, p. 1-7, 2012. (Doc. VII1.38)

Pylro, VS; Roesch, LFW; Ortega, JM; Amaral, AM; Tótola, MR; Hirsch, PR; Rosado, AS; GóesNeto, A; Silva, A; Rosa, CA; Morais, DK; Andreote, FD; Duarte, GF; Melo, IS; Seldin, L; Lambais, MR; Hungria, M; Peixoto, RS; Kruger, RH; Tsai, SM; Azevedo, V. Brazilian Microbiome Project: revealing the unexplored microbial diversity challenges and prospects. Microbial Ecology, v. 67, p. 237-241, 2014. (Doc. VII-1.58) 


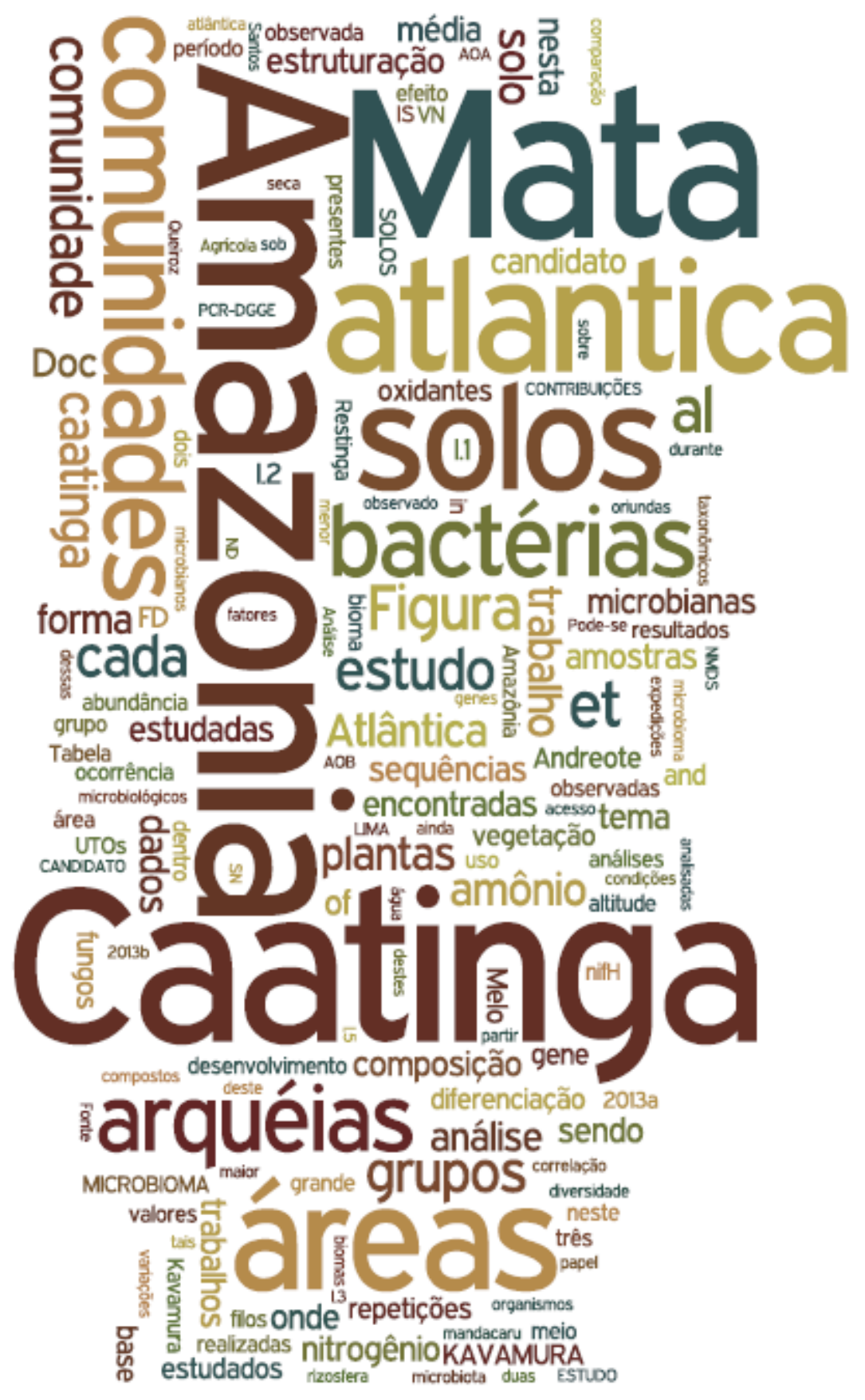

Sessão I

MICROBIOMA DE SOLOS DE BIOMAS NATURAIS 


\section{SesSão I - Microbioma de Solos de Biomas Naturais}

O fascínio pelos biomas naturais é intrínseco a todos os cientistas, que vislumbram uma área como a Amazônia como um reservatório de novidades científicas e possibilidades de inovações tecnológicas, suportadas pelo uso racional do material biológico resultante de milhões de anos de evolução. Dessa forma, entender o funcionamento dos componentes destas comunidades apetece a comunidade científica de maneira singular. Esta sessão é a menor das três, sendo composta por trabalhos pontuais, realizados pelo candidato em biomas naturais. No entanto, o desenvolvimento destes trabalhos inseriu o grupo de pesquisa num cenário mais abrangente, guiando (como exposto abaixo) os novos estudos a serem desenvolvidos.

\section{I.1. Contribuições do CANDidato no estudo do microbioma dos SOLOS DA Amazônia}

O trabalho que apresentou a participação do candidato dentro deste tema avaliou alterações na comunidade de fungos em solos da Amazônia sob diferentes condições de manejo. Este é um tema de grande interesse, onde os esforços têm levado a elaboração de trabalhos cada vez mais detalhados no entendimento da alteração do uso da terra sobre os grupos microbianos.

Fracetto, GGM; Azevedo, LCB; Fracetto, FJC; Andreote, FD; Lambais, MR; Pfenning, LH. Impact of amazon land use on the community of soil fungi. Scientia Agrícola, v. 70, p. 59-67, 2013. (Doc. VII-1.46)

Os resultados do estudo demonstraram a diferenciação que ocorre nesta comunidade quando o uso do solo é convertido de floresta para outras finalidades, com destaque para as áreas de pastagem, onde a comunidade de fungos é a mais distinta (Figura I.1). Esta observação é totalmente condizente com a literatura (KAHINDI et al., 1997; RODRIGUES et al., 2013), sendo a inovação trazida pelo acesso a comunidade de fungos de forma independente de cultivo. 


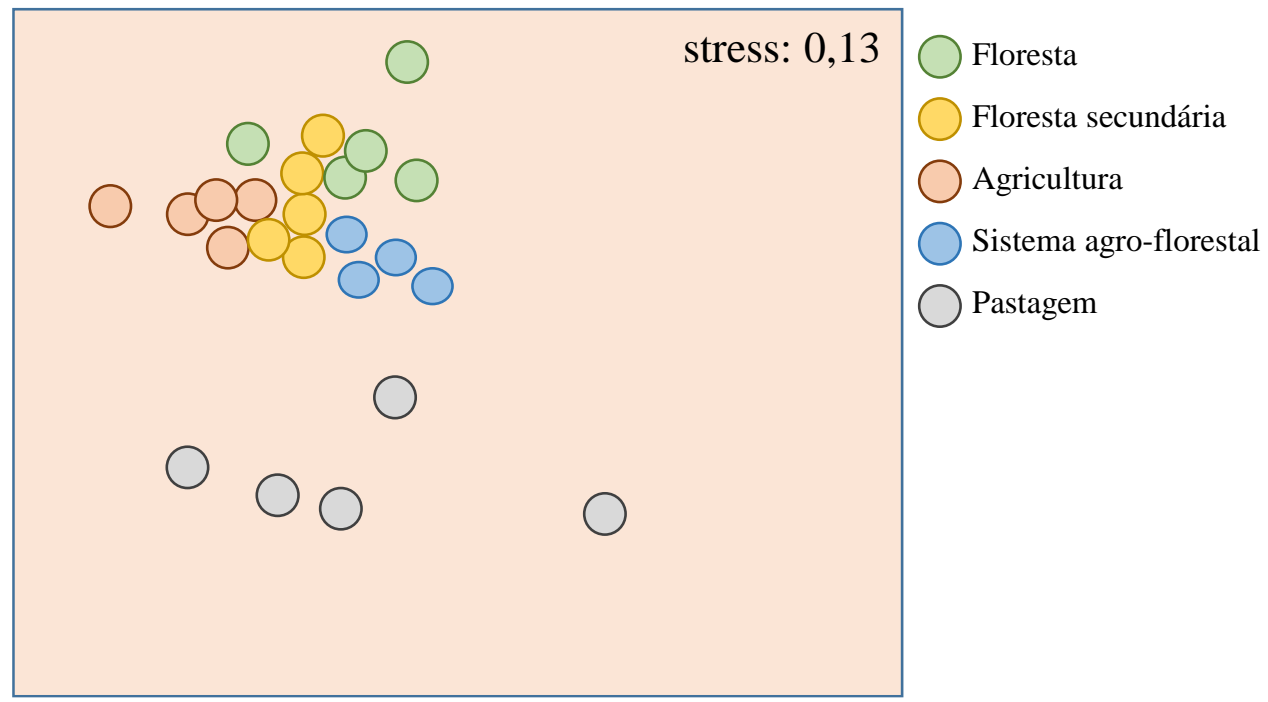

Figura I.1. Análise de non-multidimensional scaling (NMDS) com base no perfil de PCRDGGE das comunidades de fungos encontradas em solos da Amazônia sob diferentes manejos. Fonte: FRACETTO et al. (2013).

O envolvimento com o tema despertou interesse no desenvolvimento de outros trabalhos neste bioma. No ano de 2012 o candidato participou de uma proposta submetida na chamada FAPESP-NSF, que busca estudar a microbiota dos solos da Amazônia, gerando dados sobre sua diversidade, funcionalidade e ocorrência de padrões de biogeografia. A proposta não foi aprovada nesta oportunidade, mas está novamente submetida na mesma chamada de 2014, onde foi apresentada com o título 'Integrating the dimensions of microbial biodiversity across land use change in tropical forests'.

\section{I.2. CONTRIbuiÇÕES DO CANDIDATO NO ESTUdO DO MICROBIOMA DOS SOLOS DA CAATINGA}

A contribuição do candidato para o estudo do microbioma dos solos da caatinga é mais extensa, tendo seu início durante o desenvolvimento de seu pós-doutorado, e baseada na colaboração com o grupo de pesquisa liderado pelo Dr. Itamar Soares de Melo, na Embrapa Meio Ambiente (Jaguariúna). Este tema é por si só inovador, tocando em um bioma de grande extensão, porém pouquíssimo explorado do ponto de vista microbiológico. Dentro de um projeto financiado pela Embrapa, foi realizado um desenho experimental composto de áreas de caatinga encontradas em cinco estados (Bahia, Piauí, Ceará, Rio Grande do Norte e Paraíba) (Figura I.2). 


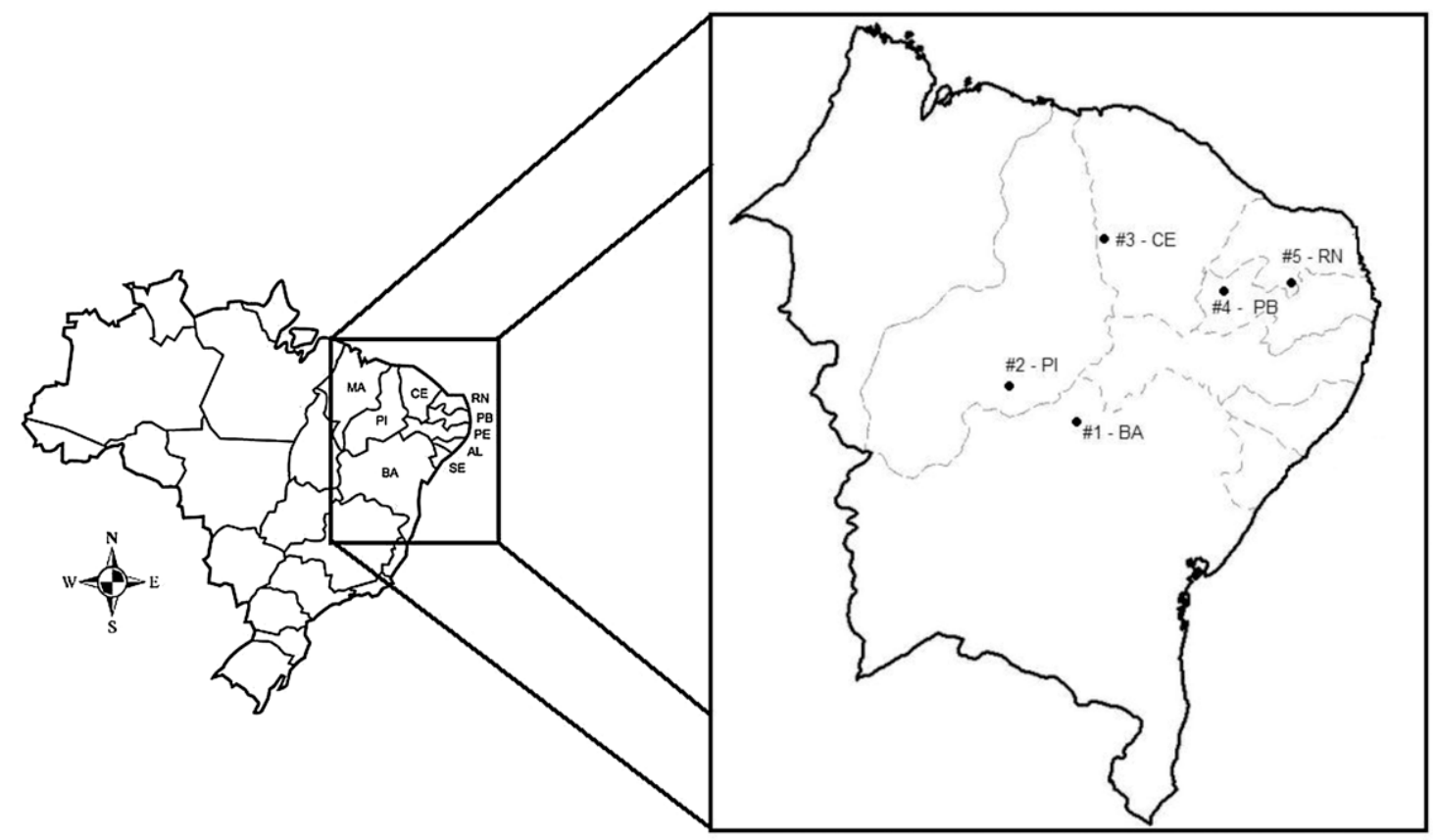

Figura I.2. Desenho amostral das área de estudo de solos da caatinga brasileira, onde foram realizadas expedições semestrais ao longo de dois anos de coletas. Fonte: KAVAMURA et al. (2013a).

Estas área foram visitadas por expedições realizadas tanto no período de seca como no período de estiagem, que conferem a este bioma uma distinção muito clara entre as estações. Nestas expedições foram coletadas amostras de solo e de rizosfera de plantas típicas da caatinga, como por exemplo, o mandacaru. A partir de tais amostras, diversas análises foram realizadas, e os resultados gerados deram origem a importantes publicações do candidato dentro deste tema:

Kavamura, VN; Taketani, RG; Lançoni, MD; Andreote, FD; Mendes, R; Melo, IS. Water Regime Influences Bulk soil and rhizosphere of Cereus jamacaru bacterial communities in the Brazilian caatinga biome. Plos One, v. 8, p. e73606, 2013a. (Doc. VII-1.54)

Kavamura, VN; Santos, SN; Silva, JL; Parma, MM; Avila, LA; Visconti, A; Zucchi, TD; Taketani, RG; Andreote, FD; Melo, IS. Screening of Brazilian cacti rhizobacteria for plant growth promotion under drought. Microbiological Research, v. 168, p. 183-191, 2013b. (Doc. VII-1.47)

Santos, SN; Kavamura, VN; Silva, JL; Melo, IS; Andreote, FD. Plant growth promoter rhizobacteria in plants inhabiting harsh tropical environments and its role in agricultural improvements. In: Dinesh K Maheshwari. (Org.). Plant Growth and Health Promoting Bacteria. 1ed.Berlim: Springer-Verlag, 2010, v. 1, p. 251-272. (Doc. VII-3.5)

Santos, SN; Kavamura, VN; Castanha, RF; Andreote, FD; Carvalho, JE; Queiroz, SCN; Melo, IS. Antitumoral, antioxidant and antimicrobial molecules from Combretum rupicola. International Journal of Pharma and Bio Sciences, v. 4, p. 422-428, 2013. (Doc. VII-1.45) 
Observa-se dentro destes, que dois trabalhos buscam descrever a microbiota dos solos da caatinga (KAVAMURA et al., 2013a e KAVAMURA et al., 2013b). O primeiro trabalho descreveu o efeito da alternância entre os períodos de seca e de chuva na composição da microbiota do solo e da rizosfera do mandacaru (KAVAMURA et al., 2013a). Foi observada uma predominância de grupos bacterianos afiliados a Proteobacteria e Acidobacteria na época de chuvas, enquanto nas amostras coletadas na época da seca foi observada a predominância dos filos Actinobacteria e Firmicutes. Essas observações indicam claramente a necessidade de uma maior resistência celular (bactérias Gram positivas) para sobreviver às condições adversas que ocorrem no período de estiagem. Este trabalho também indicou a ausência de efeito rizosférico durante o período de falta de água, revelando o metabolismo do mandacaru como um forte modulador da comunidade microbiana encontrada na adjacência das raízes desta planta típica da caatinga brasileira.

O segundo trabalho revela a capacidade de bactérias isoladas destes solos de protegerem as plantas contra o estresse hídrico. Num experimento realizado em plantas de milho inoculadas com estes organismos, foi observado que durante a falta de água a proteção exercida pelos microrganismos é mais claramente observada (KAVAMURA et al. 2013b).

O terceiro trabalho é apresentado na forma de capítulo de livro, onde a potencialidade de organismos encontrados em solos sob condições adversas (extremos de temperatura, escassez de água ou presença de salinidade) são discutidas de forma simplificada, abrangendo uma narrativa entre os biomas caatinga, Antártica e o ecossistema manguezal (SANTOS et al., 2010).

O quarto trabalho é focado no uso de compostos produzidos por fungos isolados de plantas oriundas da caatinga. Este trabalho mostrou a potencialidade de tais compostos em combaterem o desenvolvimento de células cancerígenas humanas, indicando o grande potencial de benefícios biotecnológicos que podem residir neste ainda pouco explorado bioma brasileiro (SANTOS et al., 2013).

\section{I.3. CONTRIBUiÇões do CANDIDATO NO ESTUdO DO MICROBIOMA DOS SOLOS DA MATA}

\section{AthânticA}

O estudo de solos da Mata Atlântica ocorreu de forma pontual, sendo este o tema de trabalho das duas primeiras alunas de pós-graduação orientadas pelo candidato como docente da ESALQ/USP. Esta oportunidade se deu em colaboração com a equipe coordenada pelo Prof. Dr. Marcio Rodrigues Lambais, que disponibilizou os recursos para 
a coleta das amostras, que foi realizada num gradiente altitudinal encontrado no complexo da Serra do Mar. Neste gradiente, solos de três áreas foram estudados: Santa Virgínia (altitude de 900 a $1.000 \mathrm{~m}$ ), Picinguaba (altitude de 50 a 100m) e Restinga (altitude de 0 a $5 \mathrm{~m})$.

Foram comparadas e descritas as comunidades de arquéias e bactérias, e as comunidades com participação na ciclagem do nitrogênio nestes solos. Para tanto, foram utilizadas a informação contida em genes ribossomais e nos genes relacionados a fixação biológica do nitrogênio (nifH) e oxidação do amônio (amoA). Para os grupos microbianos oxidadores de amônio, os genes amoA contidos em arquéias e bactérias foram os meios de acesso aos grupos das arquéias amônio oxidantes (AOA) e bactérias amônio oxidantes (AOB)

Este estudo apresentou a vantagem de ter se desenvolvido em áreas já previamente caracterizadas quanto a composição da vegetação, o que engrandeceu muito as análises posteriores, onde os dados microbiológicos foram combinados com outros originados das mesmas áreas.

Os trabalhos derivados dessas análises estão em fase final de preparo para publicação, sendo no momento, apenas disponíveis na forma de dissertações de mestrado:

Julia Elidia Lima. Diversidade de bactérias e arquéias em solos da mata atlântica. 2012. Mestrado em Microbiologia Agrícola, Escola Superior de Agricultura Luiz de Queiroz - USP. Bolsista CNPq. (Doc. XI.1.2.3)

Emiliana Manesco Romagnoli. Diversidade de arquéias amônio-oxidantes em solos de mata atlântica do estado de São Paulo. 2012. Mestrado em Microbiologia Agrícola, Escola Superior de Agricultura Luiz de Queiroz - USP. Bolsista Capes. (Doc. XI.1.2.4)

Sumarizando os resultados, foi observado que, ao contrário do previamente esperado, as comunidades microbianas encontradas em cada uma das áreas amostradas mostraram-se distintas, levando à indicação de fatores ambientais particulares de cada uma das áreas com papel fundamental em sua estruturação. Não foram observadas variações em relação a abundância de bactérias e arquéias. Já as comunidades associadas ao ciclo do nitrogênio, principalmente os oxidantes de amônio, apresentaram variações em sua abundância possivelmente devido a maior taxa de inundação das áreas de Restinga (menor altitude entre as três), o que desfavorece o processo de oxidação da amônia. A quantidade do gene nifH 
mostrou pequena variação entre as áreas, porém esta não pode ser atribuída facilmente a uma variável quantificada (Tabela I.1).

Tabela I.1. Quantificação de grupos taxonômicos e funcionais em solos da Mata Atlântica por meio de PCR em tempo real (log do número de cópias do gene alvo de amplificação por grama de solo). Os valores indicam a média de três repetições biológicas, sendo cada uma delas determinadas por duas repetições técnicas (amplificações independentes), seguidas do desvio padrão. Fontes: LIMA (2011); ROMAGNOLI (2011).

\begin{tabular}{lccccc}
\hline & Bactérias & Arquéias & AOA & AOB & nifH \\
\hline Santa Virgínia & $9,71 \pm 0,11$ & $8,43 \pm 0,23$ & $4,48 \pm 0,35$ & $4,56 \pm 0,39$ & $3,71 \pm 0,18$ \\
Picinguaba & $9,25 \pm 0,10$ & $8,57 \pm 0,26$ & $4,78 \pm 0,12$ & $4,50 \pm 0,36$ & $3,15 \pm 0,14$ \\
Restinga & $9,26 \pm 0,41$ & $7,91 \pm 0,67$ & $3,06 \pm 0,04$ & $2,70 \pm 0,47$ & $3,56 \pm 0,17$ \\
\hline
\end{tabular}

A estruturação das comunidades microbianas estudadas, analisadas por PCR-DGGE, revelou-se distinta entre as áreas, novamente revelando na plotagem de NMDS, maiores diferenciações na área de Restinga (Figura I.3). Destaca-se ainda nesta análise, a observação mais clara da diferenciação entre as áreas nas análises de organismos oxidadores de amônio, indicando que os fatores que tornam as comunidades microbianas estudadas distintas entre as áreas alvo, devem ter papel ainda mais determinante sobre a estruturação dessas frações da comunidade. Pode-se sugerir com os resultados apresentados, que os processos de transformação do nitrogênio ocorrem de forma diferencial, ou promovidos por grupos microbianos diferenciados, em cada uma das áreas estudadas. 


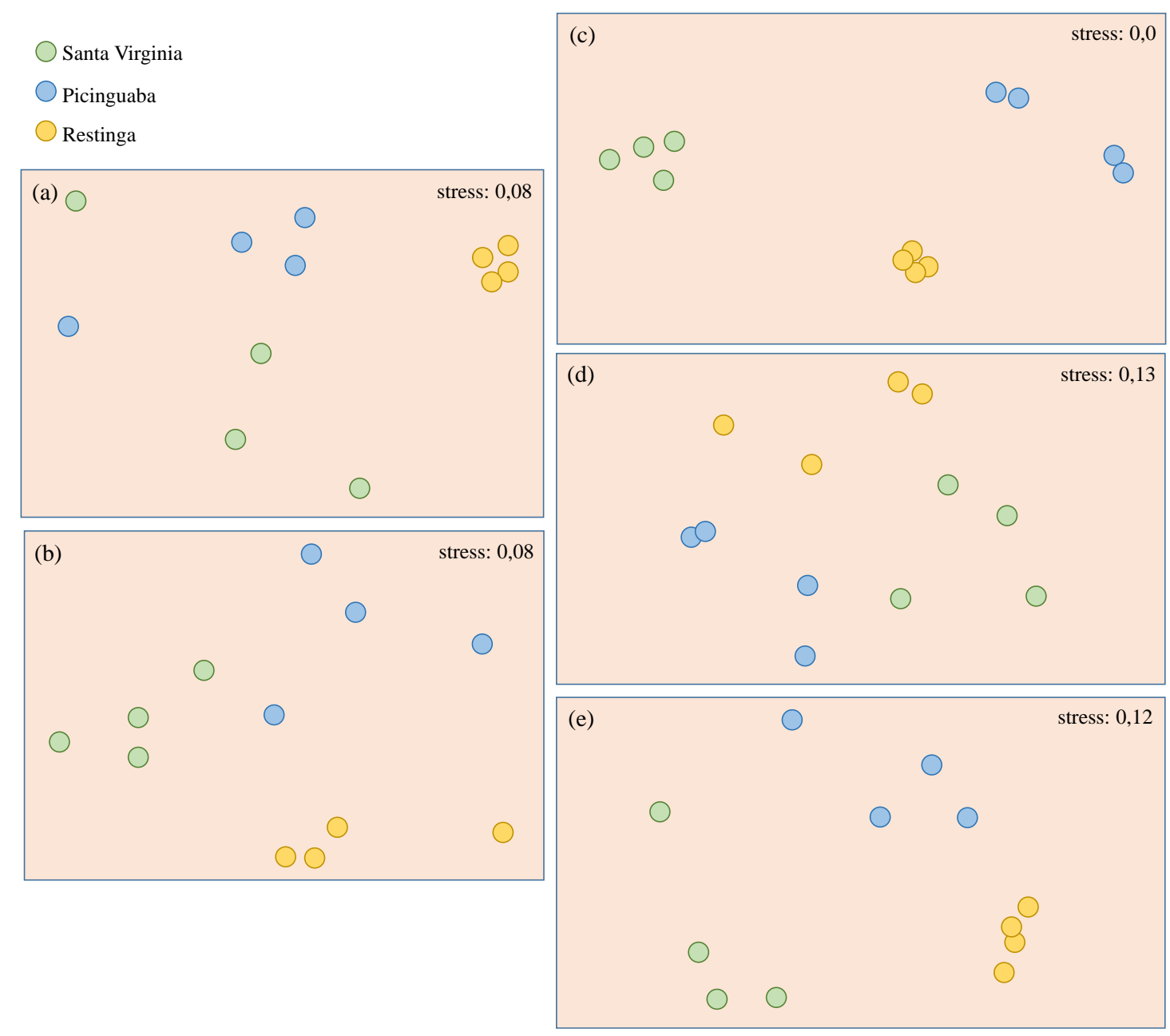

Figura I.3. Análise NMDS, com base nos perfis de PCR-DGGE, suportando a comparação das estruturas das comunidades de bactérias (a), arquéias (b), bactérias amônio oxidantes (c), arquéias amônio oxidantes (d) e bactérias fixadoras de nitrogênio (e) nos solos oriundos de Mata Atlântica. Fontes: LIMA (2011); ROMAGNOLI (2011).

A taxonomia das bactérias e arquéias presentes nos solos estudados foi acessada por meio do sequenciamento parcial do gene ribossomal 16S DNAr por pirosequenciamento. Em relação a comunidade de bactérias, foi observada uma prevalência de sequências classificadas como pertencentes ao filo Acidobacteria (média de 55,9\%), o que condiz com a ocorrência de baixos valores de $\mathrm{pH}$ associados a grandes quantidades de matéria orgânica em solos da Mata Atlântica, o que favorece o metabolismo deste grupo bacteriano (EICHORST et al., 2011). Outros grupos que foram observados como majoritários foram os filos Proteobacteria (média de 13,6\%) (com destaque para Alphaproteobacteria, Betaproteobacteria e Gammaproteobacteria) e Verrucomicrobia (média de 12,0\%). Dentro do grupo das arquéias, apenas dois filos foram observados, com a prevalência de Crenarchaeota (média de 84,0\%) e uma menor proporção de Euryarchaeota (média de 
16,0\%). Apesar de analisadas separadamente em cada uma das áreas de estudo, esta análise não evidenciou diferenças significativas na abundância relativa de grupos taxonômicos majoritários (filos e classes) entre as áreas estudadas.
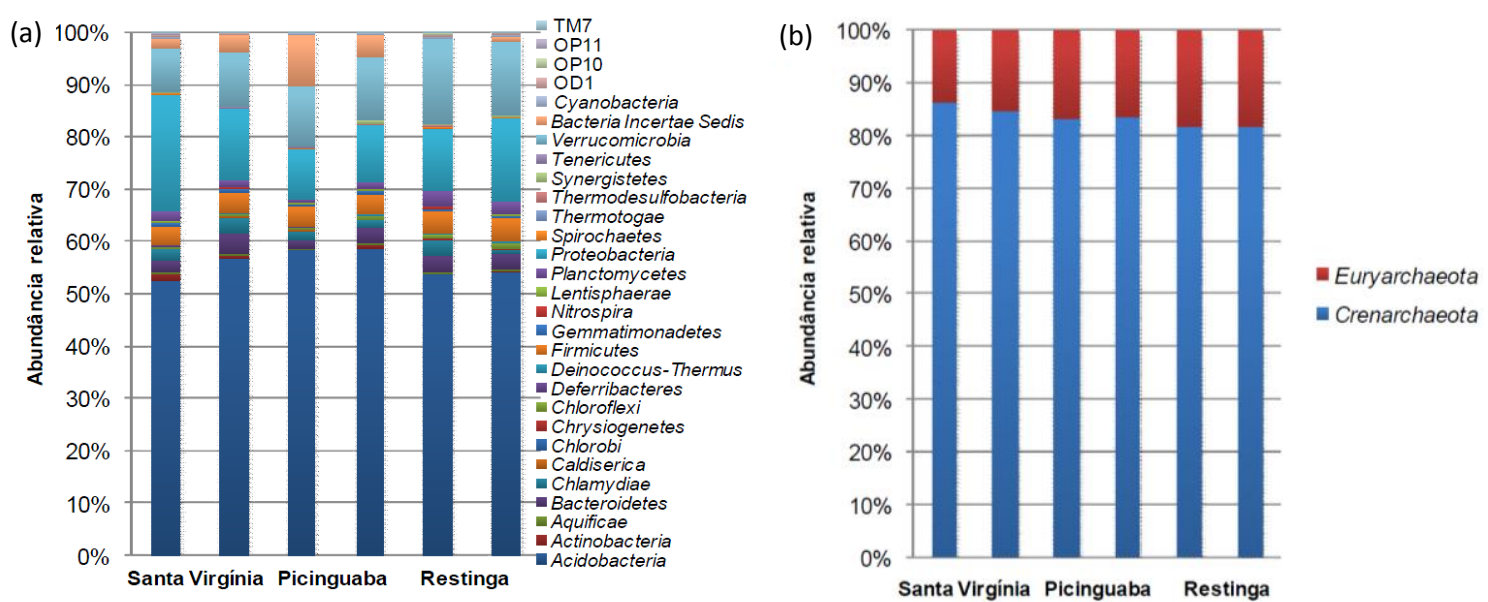

Figura I.4. Classificação taxonômica (em nível de filo) das comunidades de bactérias (a) e arquéias (b) encontradas nos solos de Mata Atlântica estudados. A abundância relativa foi determinada a partir de um número total de 25.610 sequências parciais do gene 16S DNAr de bactérias, e 6.611 sequências parciais do mesmo gene de arquéias. Fonte: LIMA (2011).

*Este estudo foi um dos primeiros a analisar repetições biológicas por meio de pirosequenciamento.

Acredita-se, portanto, que as alterações encontradas na estruturação das comunidades de bactérias e arquéias estejam relacionadas com a diferenciação de grupos taxonômicos de maior resolução, como gêneros ou 'espécies'. Métodos de análise mais refinados, com base na utilização de Unidades Taxonômicas Operacionais (UTOs), revelaram esta diferenciação taxonômica das comunidades presentes nos solos estudados (Figura I.5). Observa-se nesta análise, a separação das amostras oriundas de cada uma das áreas, e a similaridade entre as repetições avaliadas (exceto para arquéias em Sta. Virginia). Pode-se observar nesta análise, a ocorrência de UTOs compostas por sequências oriundas de diversas áreas de estudo (localizadas ao centro das figuras), e UTOs compostas exclusivamente por sequências de uma das áreas (localizadas externamente nas figuras) (Figura I.5). 

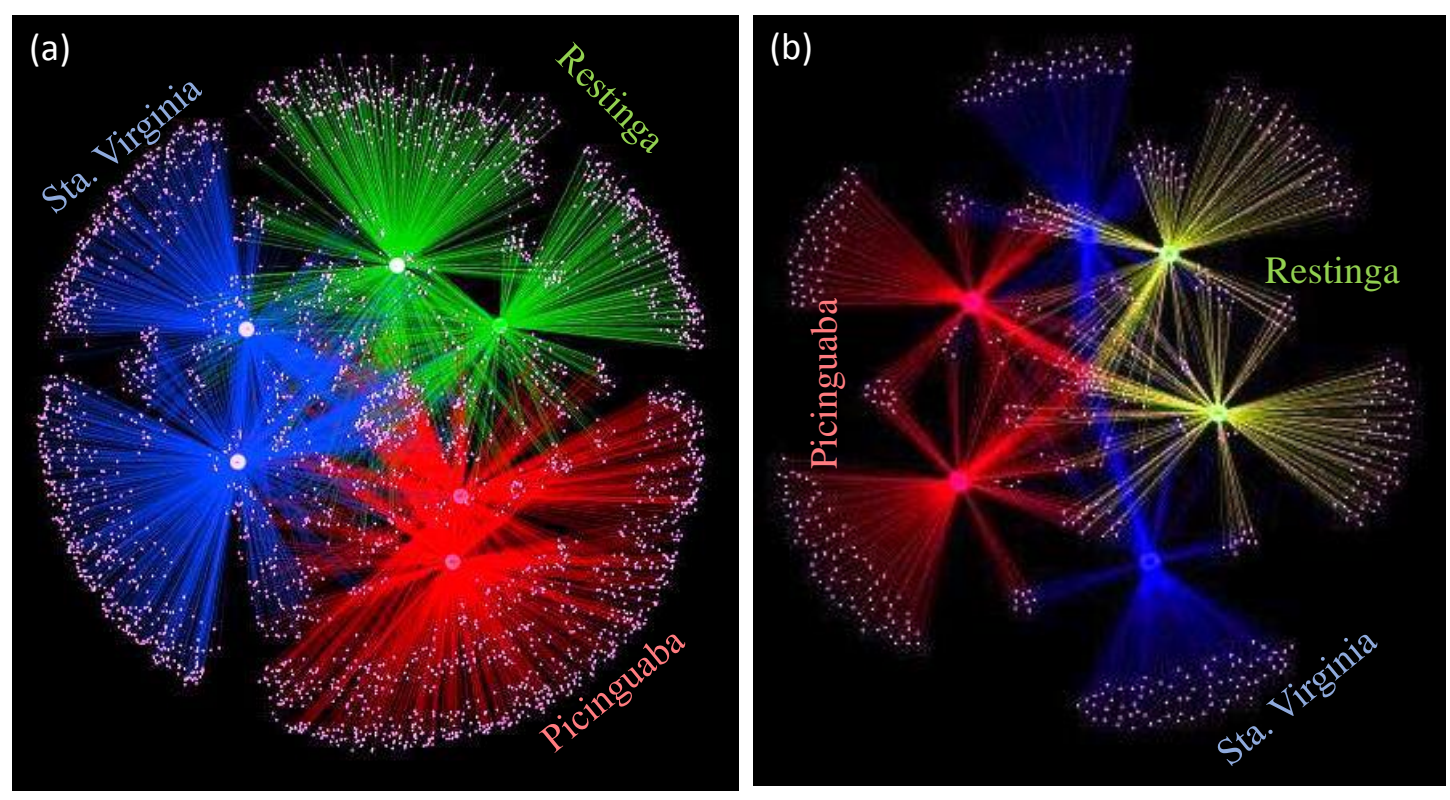

Figura I.5. Análise de coordenadas principais (PCoA), usada na comparação das comunidades de bactérias (a) e arquéias (b) encontradas nos solos estudados da Mata Atlântica. As UTOs utilizadas nesta análise foram geradas a partir das sequências obtidas em cada uma das duas repetições analisadas em cada uma das áreas estudadas, agrupadas com similaridade mínima de 97\%. Figura inédita (sem fonte).

$\mathrm{Na}$ tentativa de compreender quais seriam os fatores determinantes das variações observadas, foram realizadas correlações entre os dados microbiológicos com as características ambientais (dados físicos e químicos do solo, e composição florística das áreas). Esta inferência foi realizada com base no teste de Mantel, o qual indicou a grande correlação existente entre a composição da vegetação das áreas e a estruturação das comunidades microbianas dos solos de Mata Atlântica. A presença de plantas específicas, que neste caso se diferenciam entre as áreas amostradas, é o principal fator na diferenciação das comunidades de bactérias e arquéias nas áreas estudadas (Tabela I.2). 
Tabela I.2. Valores obtidos nas análise de correlação por meio do teste de Mantel, confrontando as segregações observadas entre as amostras com base nos dados microbiológicos, com aquelas observadas para os dados físicos e químicos do solo, e na comparação com a composição da vegetação em cada uma das áreas de estudo. Em negrito são apresentados os valores de correlação com significância estatística.

\begin{tabular}{lcccc}
\hline & \multicolumn{2}{c}{ Características do solo } & \multicolumn{2}{c}{ Composição da vegetação } \\
\cline { 2 - 5 } & Química & Física & Famílias & Gêneros \\
\hline Bactérias & 0,29 & 0,39 & $\mathbf{0 , 6 4 *}$ & $\mathbf{0 , 6 2 *}$ \\
Arquéias & 0,30 & $\mathbf{0 , 5 8 *}$ & $\mathbf{0 , 6 2 *}$ & $\mathbf{0 , 6 2 *}$ \\
AOA & 0.26 & 0.45 & $\mathbf{0 . 9 7 * *}$ & ND \\
AOB & 0.23 & 0.31 & $\mathbf{0 . 5 3} *$ & ND \\
nifH & 0,08 & 0,38 & $\mathbf{0 , 6 6 *}$ & ND \\
\hline *p<0.05; **p $<0.01 ;$ ND-não determinado & & &
\end{tabular}

Pode-se sugerir que o efeito observado ocorra por dois mecanismos principais; a liberação de exsudatos radiculares específicos, o que ativa frações diferenciadas da comunidade microbiana do solo original, tornando assim esta nova comunidade enriquecida de grupos responsivos às plantas presentes; e a decomposição de material orgânico derivado das plantas presentes, os quais podem originar compostos específicos, que teriam o mesmo efeito da rizosfera na seleção de componentes do microbioma de tais solos. Assim sendo, considerando que a diversidade de plantas dentro de uma floresta é heterogênea, esta tem papel fundamental na estruturação particular das comunidades microbianas dos solos, com destaque para as comunidades associadas com as transformações de nitrogênio neste ambiente.

Este conjunto de dados constitui o primeiro acesso detalhado das comunidades microbianas encontrados nos solos de Mata Atlântica, e revelaram a composição diferenciada dessas comunidades, compondo mais uma evidência da ocorrência de altos valores de beta diversidade em áreas de vegetação natural. 


\section{I.4 Perspectivas futuras para o estudo do microbioma de solos em biomas NATURAIS}

A observação de processos naturais de forma analítica revolucionou a ciência por diversas vezes. Pode-se adentrar nesta exposição comentando sobre o desenvolvimento da astronomia nos tempos mais remotos, ou pela descrição da Lei da gravidade, na cena conhecida por todos, onde Newton observa a queda de uma maçã. No campo das ciências biológicas, temos talvez o mais impactante de todos os trabalhos realizados de forma observacional, onde Darwin gerou a teoria sobre a Origem das Espécies, após uma longa viagem durante a qual percebeu a conformação distinta entre organismos encontrados sob condições ambientais particulares.

A fração microbiana das formas de vida que colonizam nosso planeta permaneceu por muito tempo pouco explorada, principalmente devido as dificuldades em sua observação. Com o aprimoramento das metodologias microscópicas, com a melhoria nas técnicas de cultivo microbiano, e por fim, com o desenvolvimento das metodologias independentes de cultivo, este universo microbiano fez-se presente, sendo os estudos realizados com este enfoque ainda não suficientes para descrever todos os grupos microbianos que existem nos mais diversos ambientes da Terra.

Este cenário faz dos estudos de microbiomas dos solos em biomas naturais um alvo muito atrativo, o que pode levar a diversos ganhos no conhecimento da microbiota residente em biomas que apresentam diferentes características, constituindo portanto, distintas pressões de seleção sob as quais evoluem as comunidades microbianas ali residentes.

As perspectivas do candidato neste tipo de estudo podem ser divididas entre as frentes de finalização dos trabalhos iniciados, e o início da exploração destas comunidades em novos projetos de pesquisa.

Dentre os temas apresentados nesta sessão, não existem estudos em andamento com participação do candidato nos temas Caatinga e Mata Atlântica, sendo nestes pontos apenas almejada a publicação dos resultados já obtidos sobre os microbiomas da Mata Atlântica. Já no ambiente Amazônia, existe uma grande perspectiva do desenvolvimento de um novo e amplo estudo nestes solos, dependente neste momento da aprovação da proposta enviada para a chamada FAPESP-NSF, sob o título 'Dimensions US-BIOTA-São Paulo: Collaborative research: Integrating dimensions of microbial biodiversity across land use change in tropical forests'. 
Neste projeto, o foco será colocado em dois aspectos. Primeiramente, será realizado um estudo das alterações funcionais observadas em comunidades microbianas ao longo de cronossequências geradas com a alteração no uso da terra (fronteiras agrícolas). O segundo enfoque será parte da nova linha de atuação do candidato (ainda sem financiamento, e apresentada aqui de forma inédita), onde o alvo será a alteração genômica de grupos microbianos ao longo de alterações no uso do solo. Este tipo de estudo tem como base a conhecida importância dos eventos de transferência gênica para a evolução de organismo que colonizam ambientes altamente diversos e abundantes, como os solos. A maioria dos estudos já realizados são focados na alteração na composição destas comunidades microbianas, porém não existem trabalhos que descrevem as alterações genômicas que ocorrem dentro dos componentes destas comunidades uma vez que as condições ambientais são alteradas. O estudo de cronossequências surge como um ótimo modelo para este tipo de análise. Espera-se com isto, obter dados inovadores sobre o efeito da alteração ambiental sobre a estruturação de comunidades e genomas dos componentes do microbioma do solo da Amazônia.

Um outro ambiente que apresenta características fascinantes para a exploração de seu microbioma é a Antártica. A recente participação em uma proposta aprovada, faz desta área um tema de estudo futuro do candidato, onde o mesmo deverá utilizar os solos expostos devido a retração de geleiras para o estudo da estruturação de comunidades e genomas microbianos neste ambiente. As análises deverão ser similares aquelas realizadas no ambiente amazônico, gerando uma análise comparativa de processos que podem ocorrer em ambientes muito distintos, o que confere alto grau de ancestralidade dos mesmos ao longo do processo evolutivo.

Por fim, os biomas naturais apresentam-se como oportunidades singulares para os mais diversos tipos de estudos microbiológicos, sejam estes teóricos, como os aqui apresentados, ou tecnológicos, na busca da exploração biotecnológica dos recursos biológicos ali presentes. 


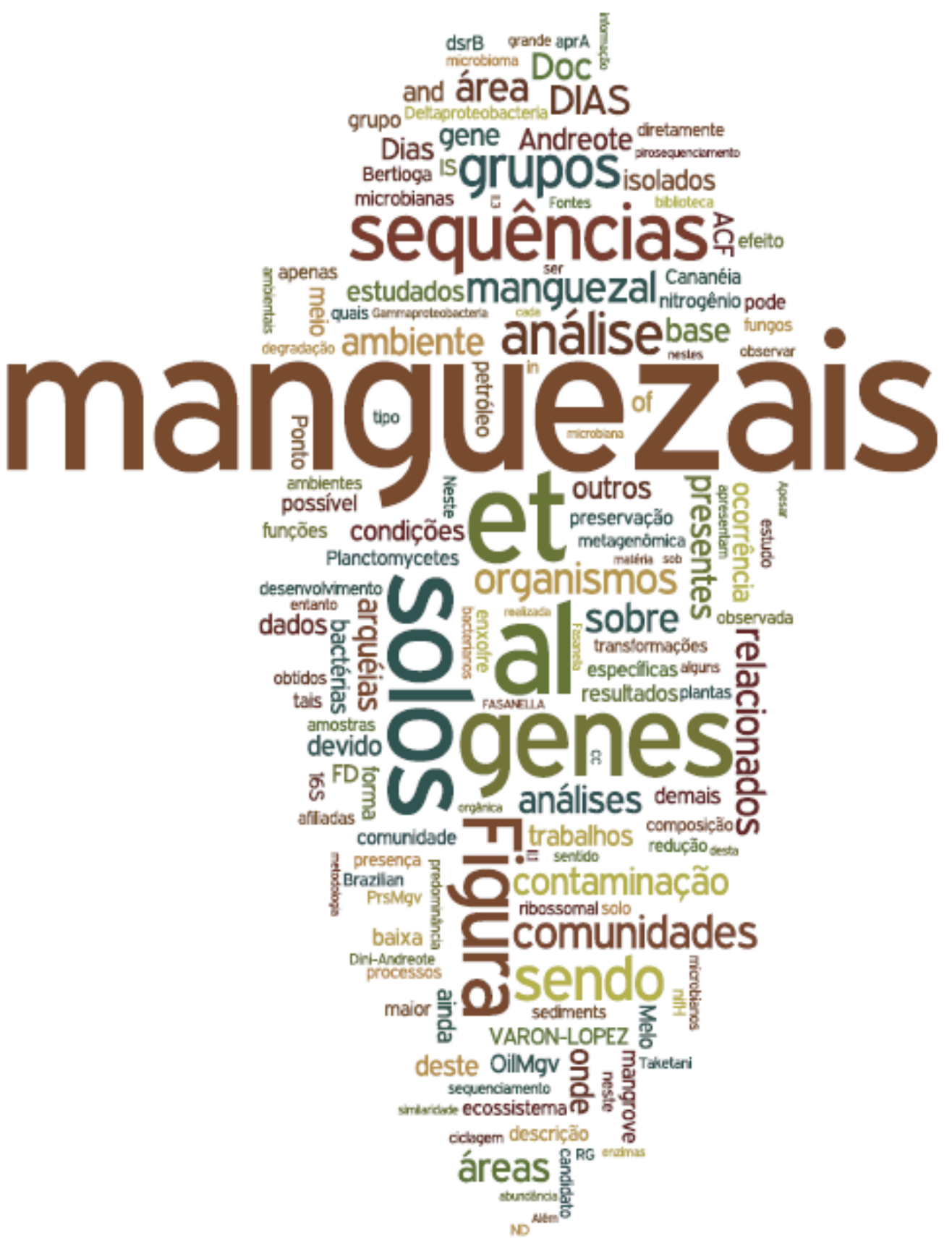

Sessão II 


\section{Sessão II - Microbioma de Solos de MAnguezais}

Esta é uma sessão mais extensa, e descreve a maior parte do trabalho desenvolvido pelo candidato em sua carreira científica. O início desta linha de trabalho se deu durante o pós-doutorado desenvolvido pelo candidato, onde o tema central foi a ecologia de grupos microbianos taxonômicos, funcionais e biotecnológicos em solos de manguezais. Por tratarse de uma das maiores áreas de sua atuação, esta sessão constará de uma descrição inicial das particularidades do ambiente alvo de estudo e da apresentação de outros trabalhos desenvolvidos neste tema, antes de adentrar sobre a contribuição científica do candidato nesta área do conhecimento.

\section{II.1. CARACTERÍSTICAS DO AMBIENTE DE MANGUEZAL}

Os ecossistemas de manguezais ocupam a região de transição entre os ambientes marinhos e terrestres em regiões tropicais e subtropicais do planeta (HOLGUIN et al., 2001; HOLGUIN et al., 2006; GIRI et al., 2011). Nas áreas de clima temperado, este local hospeda o desenvolvimento dos chamados mudflats ou saltmarshes (OLFF et al., 1997). A principal diferença entre esses ecossistemas está na presença de plantas específicas observada na área de intersecção com o mar apenas nos manguezais, ao contrário das regiões dos saltmarshes onde a presença das plantas é limitada, principalmente devido a ocorrência de baixas temperaturas durante o inverno.

Os solos de manguezais apresentam uma combinação particular de características físicas e químicas, como a prevalência de sítios de anaerobiose em decorrência das inundações promovidas pelo regime das marés; a elevada salinidade, promovida pelo aporte de água do mar; os altos teores de matéria orgânica, gerados pela lenta decomposição sob condições de baixo $\mathrm{O}_{2}$; e a baixa diversidade de plantas, devido a seleção exercida pela salinidade e a anaerobiose sobre o desenvolvimento vegetal (KATHIRESAN \& BINGHAM, 2001). No Brasil, as áreas de manguezais apresentam solos classificados como Organossolos (FERREIRA et al., 2010), e são ocupadas principalmente por três espécies de plantas (Rhizophora mangle, Laguncularia racemosa e Avicennia schaueriana), todas com adaptações responsáveis pela tolerância às condições impostas pelo meio (SCHAEFFERNOVELLI et al., 1990). Estas condições contrastantes com os ambientes adjacentes 
(marinho e terrestre), levam a questionamentos sobre o funcionamento ecológico do ecossistema manguezal.

O ambiente de manguezal possui diversas funções ecológicas e de preservação da biodiversidade, desde a multiplicação de diversas espécies de peixes e crustáceos, até a atuação na forma de proteção da linha costeira contra intempéries do oceano. Neste sentido, sabe-se que áreas costeiras adjacentes a manguezais são afetadas em uma escala muito menor quando da ocorrência de fenômenos de ressaca ou tsunamis (DUKE, 2007; SIIKAMÄKI et al., 2012). Além disso, funcionam como sumidouros de gases relacionados ao efeito estufa, principalmente devido ao acúmulo da matéria orgânica, que se decompõe de maneira lenta nesse ambiente (SIIKAM ̈̈KI et al., 2012).

No entanto, os manguezais estão entre os ecossistemas mais ameaçados de degradação, principalmente devido a sua localização, o que faz com que este tenha uma atividade de filtragem dos contaminantes provenientes do oceano e do continente. O tema contaminação de manguezais é bastante atual, e ganha destaque quando combinado com a ocorrência na proximidade de centros urbanos, ou até mesmo em áreas de exploração de petróleo em plataformas continentais (SANTOS et al., 2001). Acredita-se que sérios problemas ambientais, relacionados a alteração de regime de marés, dificuldades na manutenção da biodiversidade marinha costeira, e susceptibilidade a intempéries climáticos em regiões litorâneas, podem ocorrer se a área global ocupada por manguezais diminuir para 50\% da área atual (DUKE, 2007).

No entanto, se por um lado esta susceptibilidade torna grande a preocupação com este ambiente, por outro lado a exploração da biodiversidade presente em áreas contaminadas e/ou recuperadas pode dar base a descrição de grupos de animais, plantas e microrganismos capazes de atuar na remoção de contaminantes. Portanto, explorar de forma comparativa o microbioma de manguezais sob diferentes condições de preservação pode dar o devido suporte ao conhecimento desta comunidade e possivelmente nomear organismos e genes a serem utilizados em processos de recuperação ecológica e biorremediação em áreas degradadas.

\section{II.2. BiOlOgia doS Solos DE MANGUEZAiS}

A primeira imagem que surge ao pensarmos sobre os organismos presentes em solos de manguezais provavelmente é a de um caranguejo adentrando o solo. Estes organismos apresentam papel importante neste ecossistema, sendo suas tocas responsáveis por uma das 
poucas entradas de oxigênio nestes solos, o que influencia diretamente os demais organismos e processos que ali ocorrem. Apesar de característicos, os caranguejos, e outros organismos mais complexos, não compõem maioria nestes ambientes.

A grande diversidade de formas vitais que ocorre em solos de manguezais, assim como em todos os outros, apresenta-se na forma de células microbianas. Trabalhos pioneiros descrevem que bactérias e fungos constituem $91 \%$ da biomassa total em manguezais (ALONGI et al., 1988; ALONGI et al., 1989), sendo estes responsáveis por processos importantes, como a ciclagem de nutrientes, que forma a base da cadeia alimentar, e é responsável pela manutenção da biodiversidade da flora e da fauna no ecossistema. Portanto, o conhecimento das comunidades microbianas presentes em manguezais é de grande relevância para o melhor entendimento da dinâmica desse ecossistema, dando suporte a sua preservação, e a utilização dos recursos biológicos presentes neste ambiente.

Os primeiros trabalhos que descrevem a microbiota de manguezais utilizaram a estratégia de clonagem de genes ribossomais, nomeando como bactérias abundantes neste ambiente as pertencentes aos filos Proteobacteria, Chloroflexi, Fusobacteria, Chlamydiae/Verrucomicrobia e Planctomycetes (LIANG et al., 2007). De forma similar, o grupo das arquéias foi descrito por Yan et al. (2006), os quais encontraram os filos Crenarchaeota e Euryarchaeota como prevalentes em sedimentos de manguezais chineses. No Brasil, alguns estudos mostraram que membros dos domínios Bacteria e Archaea estão presentes em abundância e parecem ter importante função na ciclagem de nutrientes e outros processos relacionados à manutenção da capacidade produtiva dos solos desse ecossistema (CURY, 2006; DIAS et al., 2010; DIAS et al., 2011).

Desta forma, torna-se possível elucidar a dinâmica, a estrutura e a composição da comunidade microbiana, além da presença de genes relacionados a funções específicas dentro dos ciclos biogeoquímicos. Alguns trabalhos têm descrito a composição de comunidades microbianas na rizosfera de plantas tipicamente encontradas nos manguezais (CLEARY et al., 2012), e alterações causadas pela contaminação dos manguezais, sejam estas promovidas pela proximidade com centros urbanos (GOMES et al.. 2008), ou pela contaminação deste ambiente com petróleo (SANTOS et al., 2011). 


\section{II.3. CONTRIBUIÇÕES DO CANDIDATO NESTE TEMA}

Dentro do contexto exposto, o candidato tem desenvolvido diversos trabalhos, os quais auxiliam na descrição da microbiota dos solos de manguezais, bem como inferem sobre os processos biogeoquímicos realizados pela comunidade microbiana neste ambiente.

\section{II.3.1. Descrição da diversidade microbiana em solos de manguezais}

As peculiaridades dos manguezais propicia a ocorrência de espécies de animais e plantas diferenciadas e em alguns casos endêmicos a este ecossistema. Em relação aos microrganismos, acredita-se que estes possuam também habilidades específicas para a eficiente colonização deste ambiente. Assim sendo, a descrição das comunidades microbianas presentes nos solos de manguezais é de extrema importância, bem como sua comparação com os demais tipos de solos.

Neste sentido, os principais trabalhos desenvolvidos pelo candidato foram realizados com base em três áreas amostrais, localizadas no litoral do Estado de São Paulo, sendo duas localizadas no município de Bertioga e uma localizada na Ilha do Cardoso, cidade de Cananéia (Figura II.1). Os manguezais selecionados apresentam características diferenciais entre si. O manguezal situado no município de Bertioga é contaminado com petróleo (OilMgv), devido a um derramamento de 35 milhões de litros de óleo cru, ocorrido no ano de 1983. Apesar do longo tempo da contaminação, sua mata nativa apresenta-se ainda em processo de regeneração. A segunda área amostral caracteriza-se pela ausência do derramamento de óleo, porém ainda com a pressão de contaminantes oriundo da proximidade da área com o centro urbano das cidades de Bertioga, Santos e Cubatão (AntMgv). Em contraste, o terceiro manguezal, localizado no município de Cananéia, encontra-se situado em uma área de reserva ambiental na Ilha do Cardoso (PrsMgv), apresentando como fator externo de impacto um baixo efeito antrópico, decorrente da ação dos pescadores, coletores locais de caranguejo e índios moradores da ilha.

Em alguns estudos, onde o número de amostras precisou ser reduzido, estas áreas foram distribuídas em quatro regiões distintas, geradas com base tanto nos dados de preservação ambiental, como nos dados microbiológicos apresentados a seguir. O ponto 1 do manguezal contaminado (OilMgv) apresenta um menor efeito deste evento, uma vez que o petróleo derramado não atingiu este local como os demais, portanto esta área foi chamada de BrMgv01. Os demais pontos deste manguezal compõem a área de maior efeito do petróleo, chamado em alguns estudos de BrMgv02 (pontos 2 e 3 do OilMgv). Os outros dois 
manguezais apresentaram-se mais uniformes ao longo dos transectos estudados, sendo portanto ambos compostos de uma única área cada, onde o AntMgv deu origem ao BrMgv03 e o PrsMgv foi chamado de BrMgv04.

Além dos fatores ambientais e antrópicos distintos considerados entre os dois manguezais, pode ser salientada também a diferencial disponibilidade de oxigênio, quantidade de nutrientes e matéria orgânica, entre os manguezais estudados. Dentre estes fatores, algumas variáveis com grande diferença são a salinidade e a condutividade elétrica, as quais podem estar ligadas a inundação do manguezal de Cananéia diretamente pelo mar, enquanto que o manguezal de Bertioga é banhado por uma mistura de água oriunda do mar e do rio Iriri.

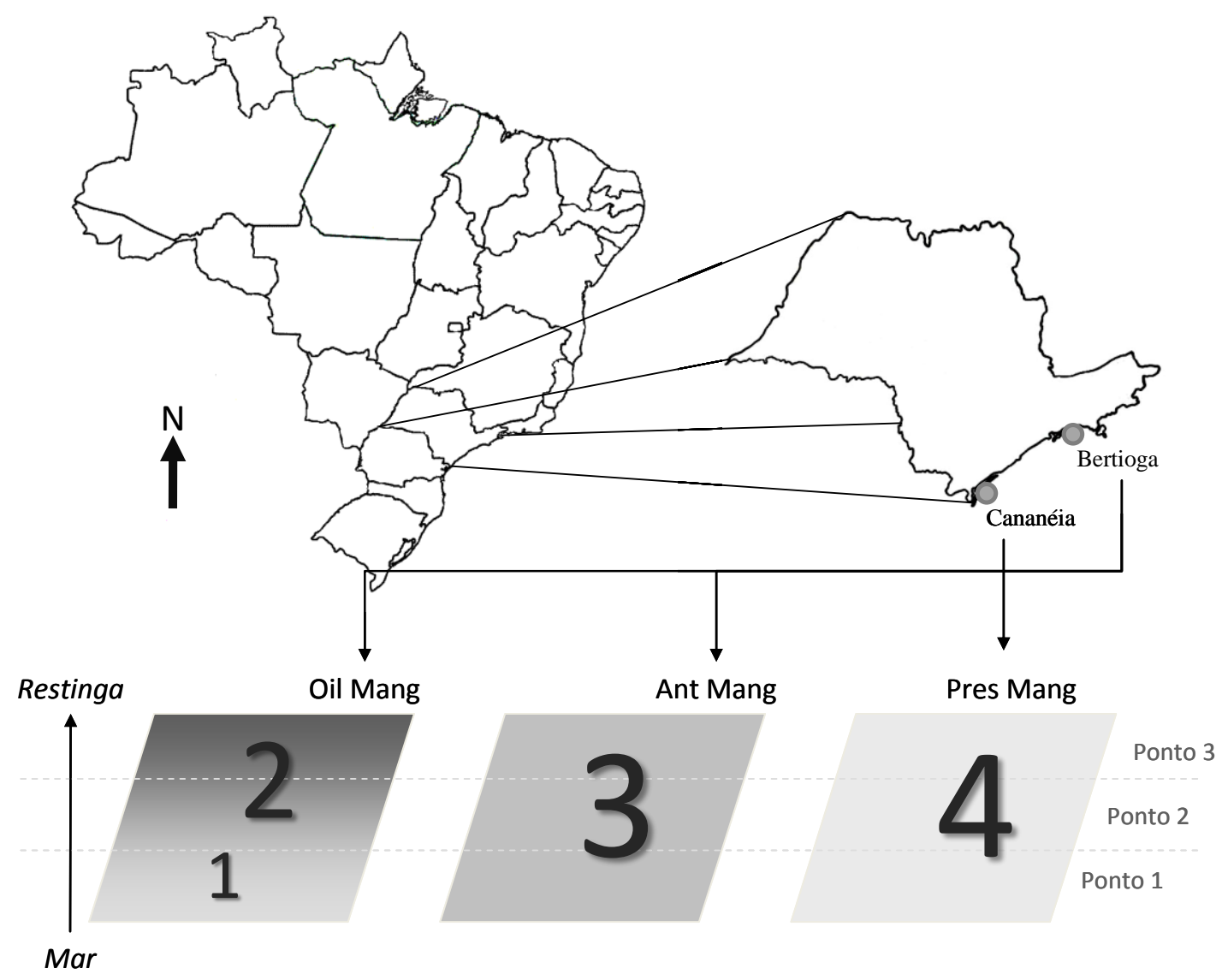

Figura II.1. Localização dos manguezais alvo de estudo. O gradiente no manguezal chamado OilMgv indica a contaminação por petróleo, mais intensa na área próxima ao continente, e com baixa intensidade na área próxima ao corpo de água. Os números de 1 a 4 indicam a divisão das amostras para as análises de metagenômica e metatranscriptômica. Fontes: DIAS et al. (2011), FASANELLA et al. (2012) e ANDREOTE et al. (2012). 
Neste desenho experimental, os principais trabalhos desenvolvidos pela equipe do candidato foram:

Dias, ACF; Andreote, FD; Rigonato, J; Fiore, MF; Melo, IS; Araújo, WL. The bacterial diversity in a Brazilian non-disturbed mangrove sediment. Antonie van Leeuwenhoek, v. 98, p. 541-551, 2010. (Doc. VII-1.20)

Dias, ACF; Dini-Andreote, F; Taketani, RG; Tsai, SM; Azevedo, JL; Melo, IS; Andreote, FD. Archaeal communities in the sediments of three contrasting mangroves. Journal of Soils and Sediments, v. 11, p. 1466-1476, 2011. (Doc. VII-1.28)

Fasanella, CC; Dias, ACF; Rigonato, J; Fiore, MF; Soares Jr, FL; Melo, IS; Pizzirani-Kleiner, AA; van Elsas, JD; Andreote, FD. The selection exerted by oil contamination on mangrove fungal communities. Water, Air and Soil Pollution, v. 223, p. 4233-4243, 2012. (Doc. VII-1.40)

Andreote, FD; Jimenez, DJ; Chaves, D; Dias, ACF; Luvizotto, DM; Dini-Andreote, F; Fasanella, CC; Baena, S; Lopez, MV; Taketani, RG; Melo, IS. The microbiome of Brazilian mangrove sediments as revealed by metagenomics. Plos One, v. 7, p. e38600, 2012. (Doc. VII-1.42)

Maryiemy Varón Lopez. Descrição da microbiota relacionada às transformações do enxofre em sedimentos de manguezais. 2013. Doutorado em Microbiologia Agrícola, Escola Superior de Agricultura Luiz de Queiroz - USP. Bolsista Capes. (Doc. XI.1.1.2)

Juliana Eschlooz de Araújo. Detecção e análise de sequências de Planctomycetes em metagenomas de manguezais. Mestrado em Microbiolgia Agrícola, Escola Superior de Agricultura Luiz de Queiroz - USP. Bolsista FAPESP. (Doc. XI.1.2.9)

Sumarizando estes trabalhos, pode-se observar que a composição e a estrutura das comunidades microbianas encontradas em cada uma das áreas de estudo encontra-se diretamente relacionada com a condição de preservação dos manguezais (Figura II.2). Isto evidencia a necessidade de preservação de tais áreas à manutenção de grupos microbianos ainda inexplorados, e possivelmente responsáveis por importantes funções metabólicas, as quais podem também apresentar um interesse biotecnológico. Dentre as alterações observadas, é claro o efeito da contaminação por petróleo sobre a estrutura das comunidades de bactérias, arquéias e fungos nas áreas estudadas (Figura II.2). Estas alterações são incitadas por processos de seleção, diretamente ligados a promoção do desenvolvimento de grupos que usam os hidrocarbonetos (ou outros contaminantes) em seu metabolismo, ou pela seleção indireta, sendo a presença do contaminante um componente de alteração das condições ambientais que selecionam os componentes da comunidade. Um exemplo deste 
efeito indireto pode ser a maior taxa de anaerobiose do solo, acoplada a menores valores de potencial redox, promovida pela entrada do óleo no manguezal OilMgv.
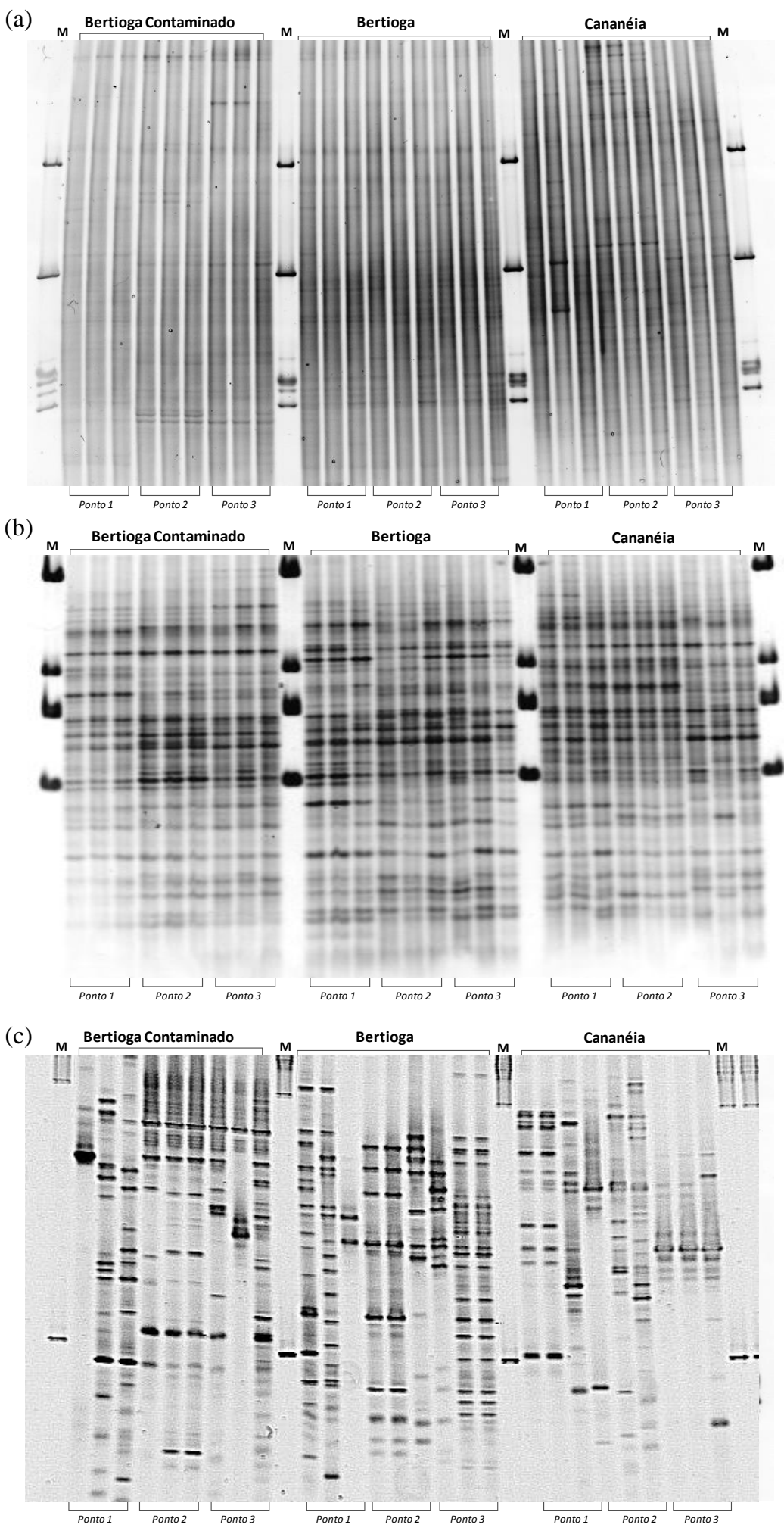

Figura II.2. Comparação das comunidades de bactérias (a), fungos (b) e arquéias (c) dos manguezais estudados (OilMgv, AntMgv e PrsMgv) determinadas por meio de PCR-DGGE. Fontes: DIAS et al. (2011) e FASANELLA et al. (2012). 
Além das análises de fingerprinting, é também importante a utilização de metodologias baseadas em sequências, o que permite inferir sobre a taxonomia dos organismos componentes das comunidades acessadas.

Neste sentido, a comunidade bacteriana nestes manguezais foi descrita em uma série de ensaios, que aumentaram em complexidade ao longo do desenvolvimento desta linha de pesquisa. Inicialmente, este grupo de microrganismos foi acessado pela metodologia de biblioteca de clones, onde 166 sequências foram obtidas a partir de amostras do solo do manguezal localizado na cidade de Cananéia (PrsMgv). A análise das sequências revelou a predominância de bactérias afiliadas a Alphaproteobacteria (40,36\%), Gammaproteobacteria (19,28\%) e Acidobacteria (27.71\%) (DIAS et al., 2010), enquanto que grupos minoritários se afiliaram a Betaproteobacteria, Deltaproteobacteria, Firmicutes, Actinobacteria e Bacteroidetes (Figura II.3).

Porém, quando avaliadas as comunidades dos manguezais de Bertioga e Cananéia por pirosequenciamento com base no gene ribossomal 16S RNAr, foi observado uma configuração diferenciada da comunidade bacteriana do manguezal de Cananéia quando comparado ao estudo anterior (VARON-LOPEZ, 2013). Tanto em Cananéia como Bertioga, foi observada uma predominância de sequências afiliadas a Deltaproteobacteria e Gammaproteobacteria (Figura II.3). A diferença observada entre os resultados oriundos de metodologias distintas levantou dúvidas sobre a real composição de tais comunidades, o que foi solucionado pela análise sequenciamento do DNA extraído diretamente de amostras destes solos (ANDREOTE et al., 2012). Nesta análise, foi possível observar não apenas a afiliação taxonômica de sequências de genes ribossomais, mas também de sequências de outros genes bacterianos, sendo os resultados similares ao observados por pirosequenciamento, com predominância para os grupos Deltaproteobacteria e Gammaproteobacteria (Figura II.3).

A prevalência dos grupos Deltaproteobacteria e Gammaproteobacteria torna os solos de manguezais diferenciados quando comparados a solos de outros biomas, onde se costuma observar uma predominância de Alphaproteobacteria e Betaproteobacteria (JANSSEN, 2006). Esta diferenciação se deve a prevalência das condições anaeróbicas em tais solos, o que favorece o metabolismo anaeróbico das Deltaproteobacteria, como por exemplo, a redução de sulfato. 
(a)

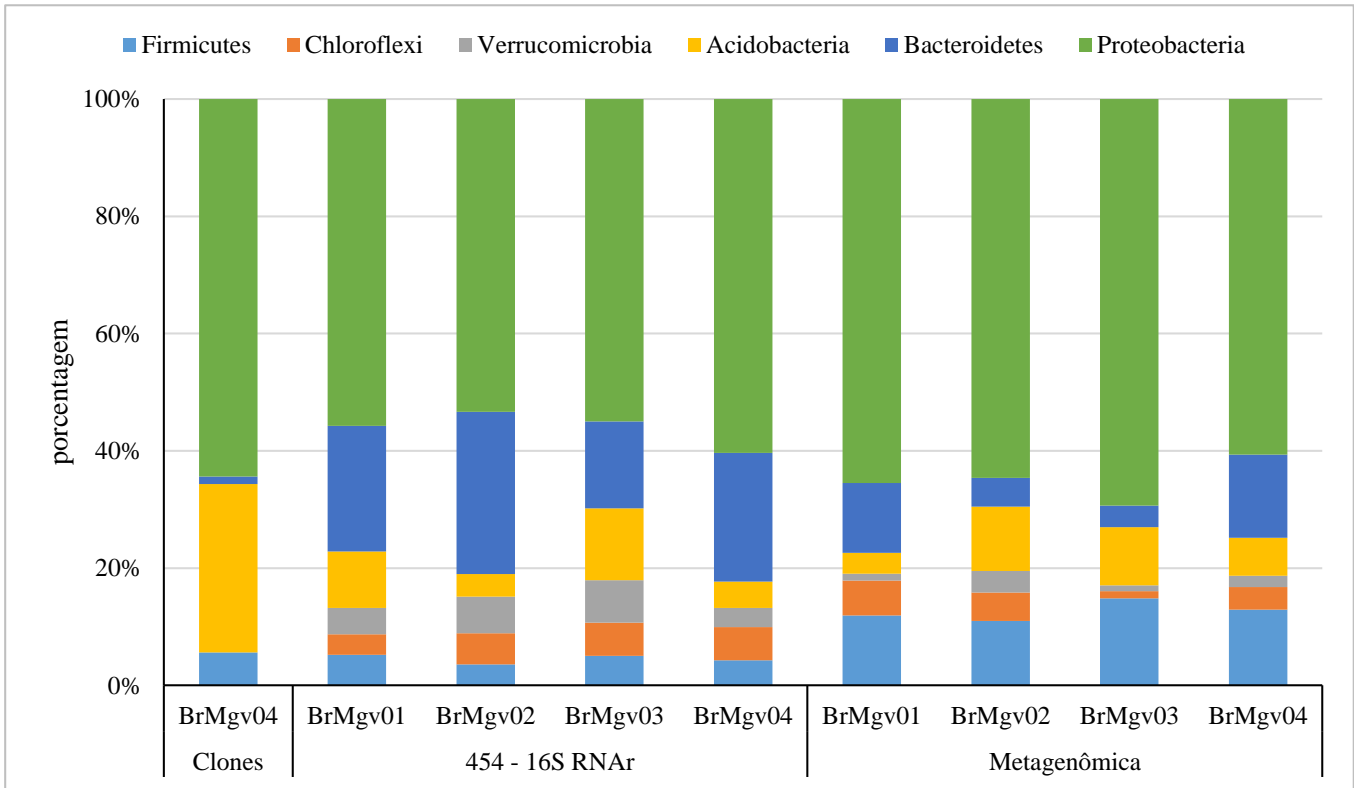

(b)

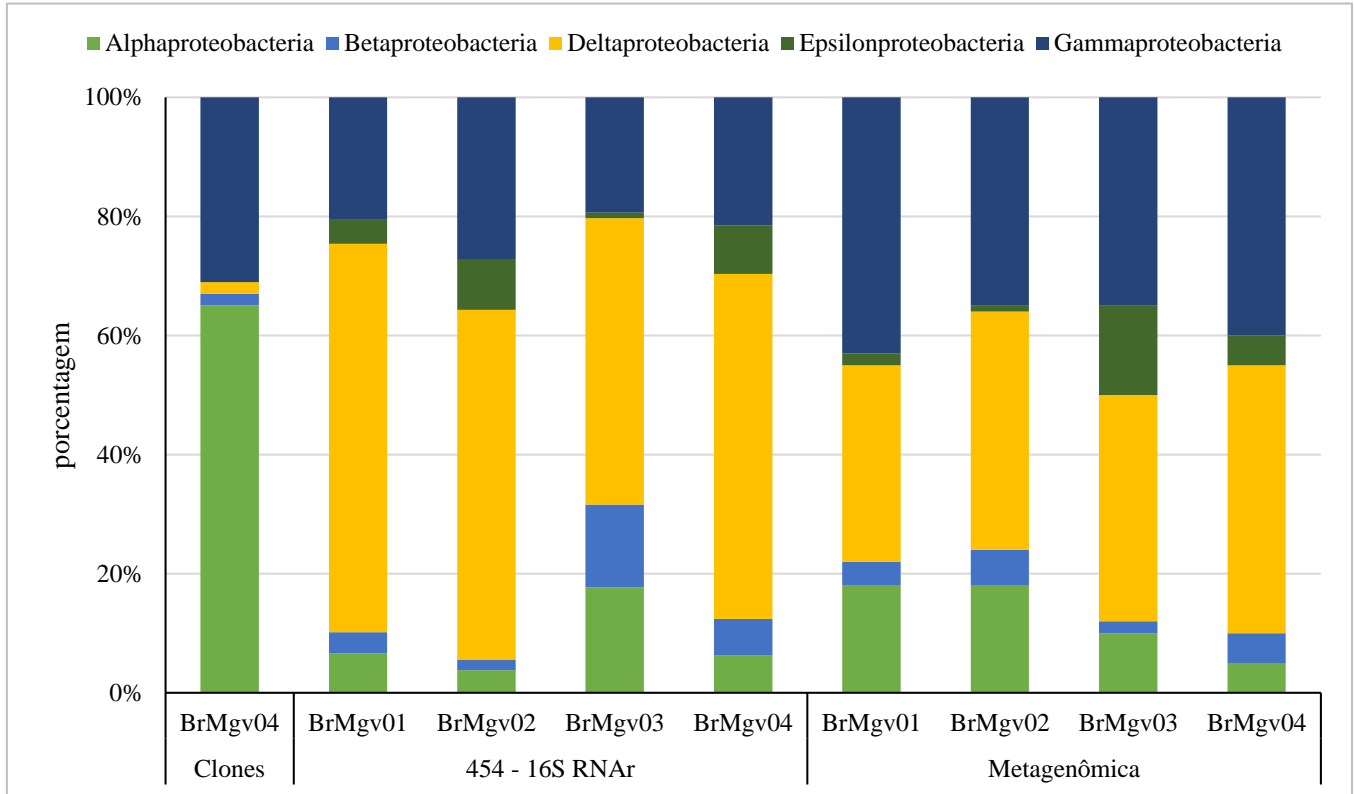

Figura II.3. Filos (a) e classes dentro de Proteobacteria (b) mais frequentes na composição das comunidades bacterianas dos manguezais estudados, acessadas por meio de biblioteca de clones do gene ribossomal 16S RNAr (166 sequências), pirosequenciamento de amplicons da região V4 do gene ribossomal 16S RNAr (30.947 sequências), e sequenciamento do DNA extraído das amostras de solo (metagenômica) (1.098.802 sequências). Fontes: DIAS et al. (2010), VARONLOPEZ (2013) e ANDREOTE et al. (2012).

A composição das comunidades de arquéias foi também realizada em duas etapas, porém ambas baseadas no sequenciamento de genes ribossomais. Inicialmente, a descrição foi feita com base em uma amostra composta de todos os manguezais, representados por 81 sequências, indicando uma predominância de sequências afiliadas a Thaumarcheaota 
(antigamente classificada como Crenarchaeota) ${ }^{2}(53,1 \%)$ e Euryarcheaeota $(29,5 \%)$, além da presença de um grupo não afiliado a filos conhecidos (16,1\%) (Figura II.4). A análise posterior, realizada separadamente para cada uma das áreas, e com base na metodologia de pirosequenciamento, confirmou a tendência observada anteriormente, com sequências afiliadas a Thaumarchaeota (Crenarchaeota) $(48,6 \%)$, Euryarchaeota $(42,6 \%)$ e arquéias não classificadas $(8,7 \%)$. Pode-se ainda extrair desta análise, uma possível alteração entre os grupos de arquéias detectados devido a contaminação ambiental dos manguezais (Figura II.4). Neste sentido, observa-se um aumento das sequências afiliadas a Euryarchaeota na área chamada de BrMgv02 (pontos 2 e 3 de OilMgv), onde está localizada a maior contaminação de petróleo. No entanto, este aumento também se apresenta na área BrMgv04, que é composta pelo manguezal PrsMgv, dificultando conclusões sobre esta alteração ao nível de filo.

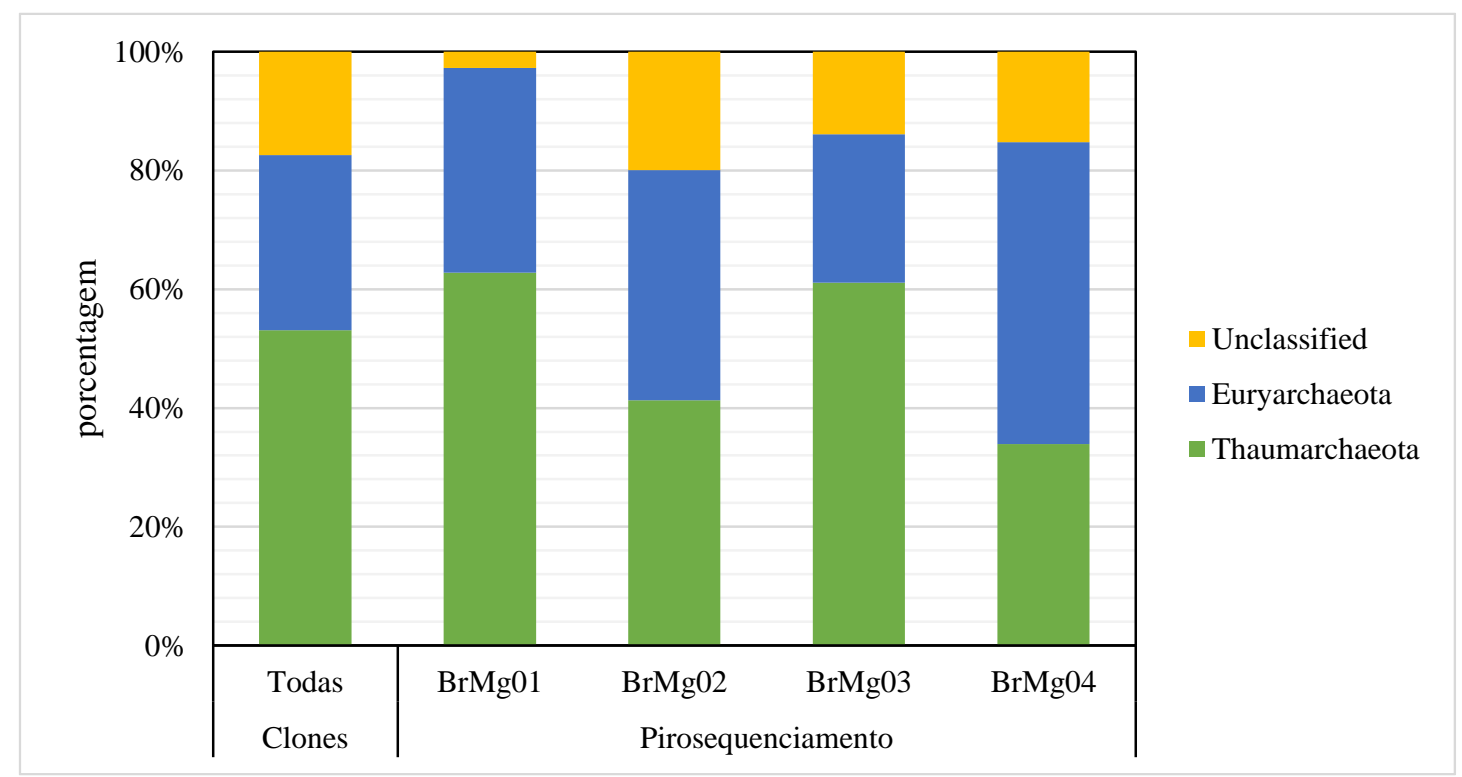

Figura II.4. Composição das comunidades de arquéias em solos dos manguezais estudados acessadas por meio de biblioteca de clones do gene ribossomal 16S DNAr (81 sequências), pirosequenciamento de amplicons da região V4 do gene ribossomal 16S RNAr (4.255). Fontes: DIAS et al., (2011) e VARON-LOPEZ (2013).

Para o grupo dos fungos, além da análise comparativa das áreas por meio de PCRDGGE, foi realizada uma descrição com base em sequenciamento da região ITS, onde foram analisadas apenas amostras dos manguezais localizados na cidade de Bertioga. Nesta análise

\footnotetext{
${ }^{2}$ A problemática na diferenciação entre os filos Crenarchaeota e Thaumarchaeota está no fato de o banco de dados mais utilizado para a afiliação das sequências (Ribossomal Database Project) não ter estabelecido tal diferenciação.
} 
foram utilizadas 180 sequências, as quais indicaram a predominância de grupos afiliados a Epicoccum, Nigrospora, Cladosporium e basidiomicetos não identificados (Figura II.5). Esta análise também indicou uma prevalência do grupo de Basidiomycota na área contaminada, mostrando uma ocorrência diferenciada dos grupos de fungos nos manguezais em função da contaminação (FASANELLA et al., 2012).

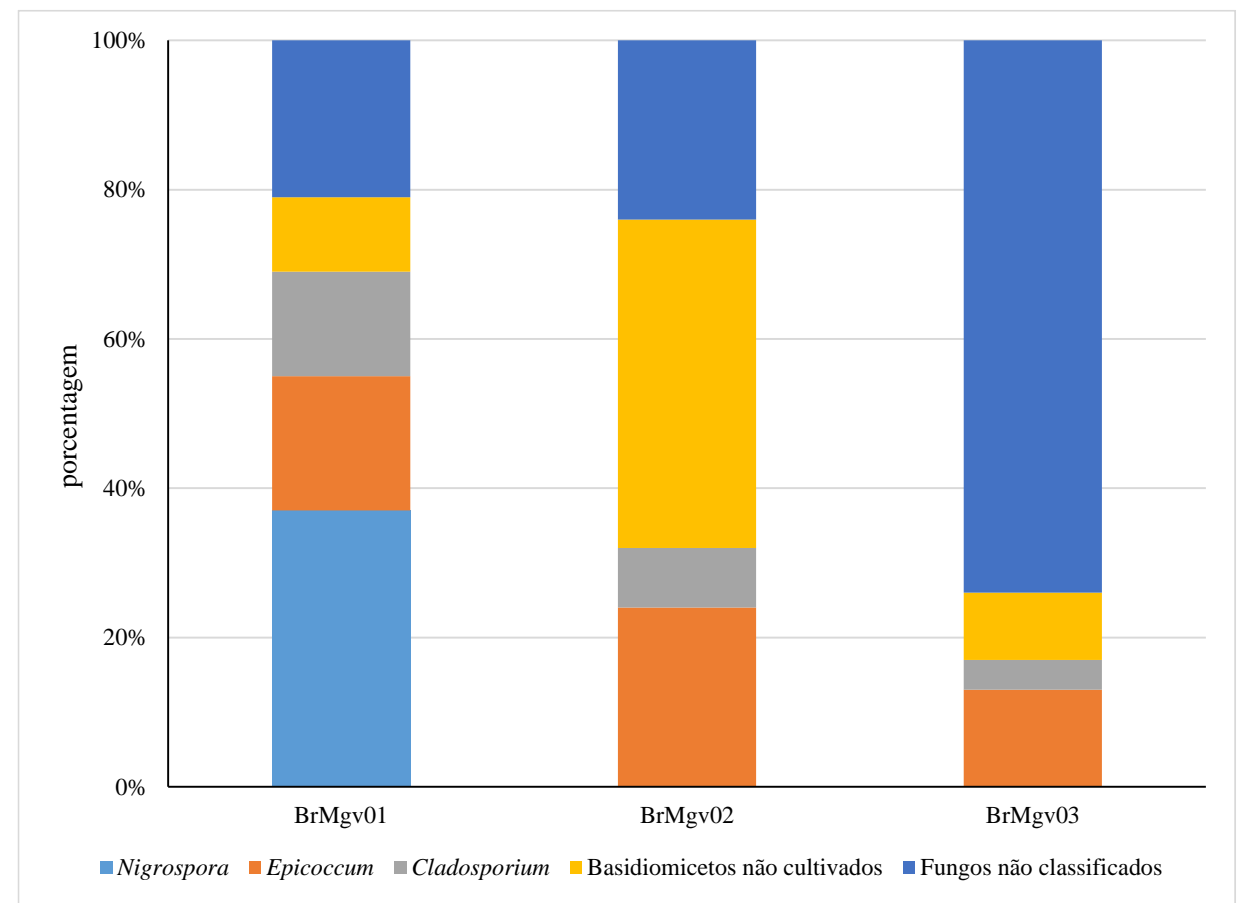

Figura II.5. Composição das comunidades de fungos dos solos dos manguezais estudados acessadas por meio de biblioteca de clones da região ITS do operon ribossomal (180 sequências). Fonte: FASANELLA et al. (2012).

Uma outra possibilidade de aprofundar nossos conhecimentos sobre a microbiota destes solos está no acesso da informação genômica de grupos bacterianos de importância no ambiente estudado. Neste intuito, um trabalho recente focou o acesso a informação genômica de bactérias afiliadas a Planctomycetes nos solos dos manguezais. Este grupo foi selecionado devido a habilidade de alguns destes organismos promoverem a oxidação anaeróbica da amônia (anammox). Para tanto, juntamente com o estudo de genes pertencentes a estes organismos (métodos independentes de cultivo), também foi realizado o cultivo dos mesmos, sugerindo que os representantes deste grupo taxonômico ainda pouco estudados, são passíveis de cultivo a partir de amostras de manguezais. Esta combinação de metodologias busca gerar informações sobre a similaridade genética entre os Planctomycetes encontrados nos manguezais com os previamente obtidos de outros ambientes, bem como almeja a obtenção de dados sobre sua organização genômica e metabolismo. 
Acessando a informação genética de isolados de Planctomycetes, foi possível observar agrupamentos específicos de sequências oriundas apenas dos solos de manguezais, indicando um possível endemismo desse importante grupo nos solos estudados (Figura II.6). A inclusão das sequências oriundas dos isolados nesta análise demonstraram a capacidade de se recuperar na forma de colônias, representantes dos principais grupos afiliados a Planctomycetes em solos de manguezais (Figura II.6). Assim sendo, a complementação deste estudo está em desenvolvimento e é composta pelo sequenciamento dos genomas dos isolados obtidos.

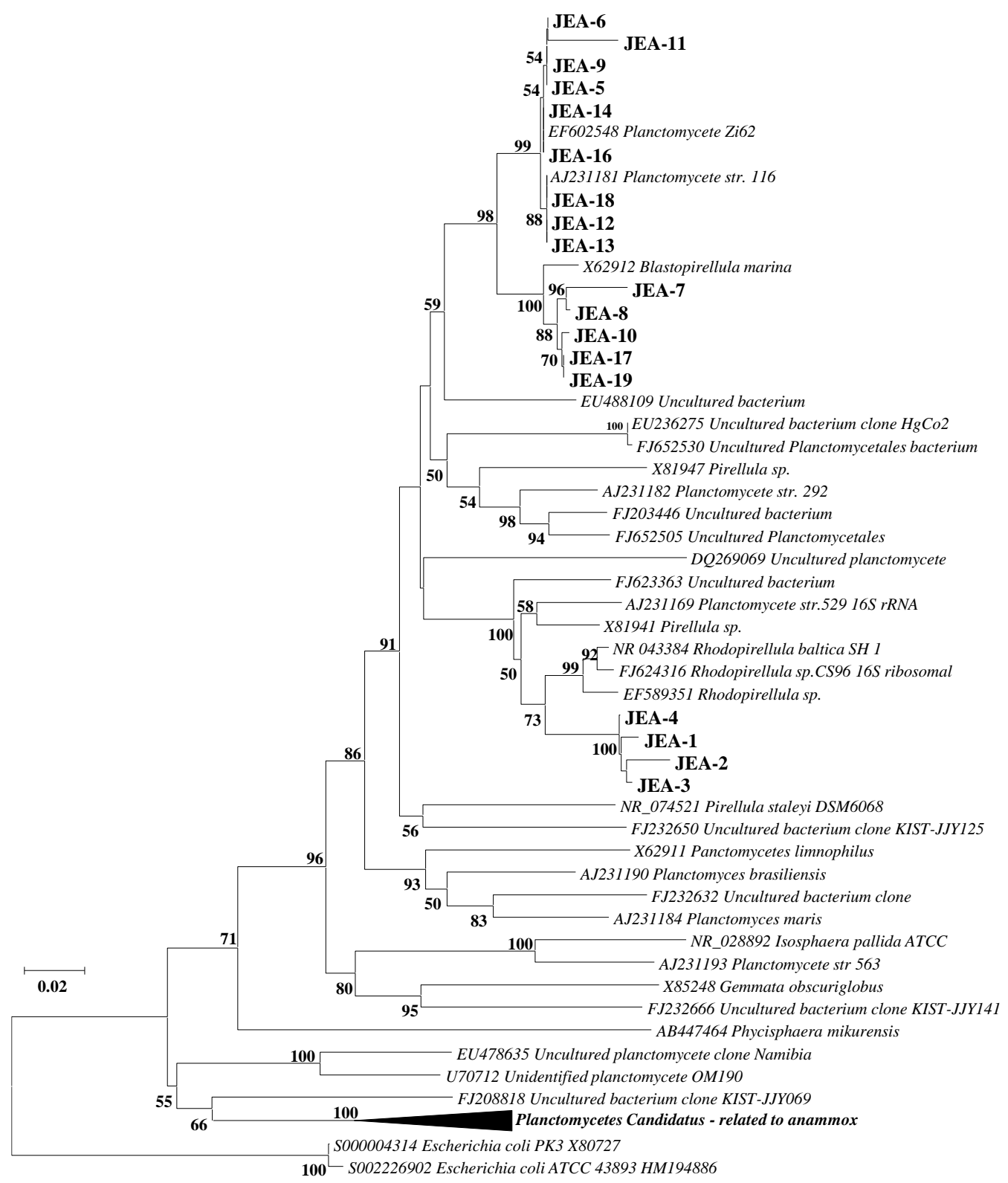

Figura II.6. Afiliação das sequências parciais do gene ribossomal 16S RNAr dos isolados bacterianos afiliados ao filo Planctomycetes, onde os isolados obtidos a partir de amostras de manguezais são apresentados em negrito (nomeados JEA). Fonte: ARAÚJO (2014). 
Todas estas análises revelaram-se de grande importância para o conhecimento dos organismos que compõem o microbioma dos solos de manguezais. No entanto, considerando a grande fluidez que existe na troca de material genético entre os componentes de uma comunidade microbiana complexa, faz-se necessária a realização de análises focadas em genes codificadores de proteínas/enzimas catalisadores de transformações específicas nestes solos, os chamados genes funcionais.

\section{II.3.2. Acesso a genes relacionados a funções específicas em solos de manguezais}

Os resultados obtidos com base nos genes ribossomais mostraram-se promissores, e levaram a ampliação das análises para genes relacionados a funções específicas. Neste sentido, foram alvos de estudos os genes relacionados a fixação biológica do nitrogênio (nifH), nitrificação ( $a m o A$ - detectado apenas em arquéias), redução e oxidação do enxofre ( $d s r B$ e aprA). Além de análises específicas, a metodologia de metagenômica possibilitou a descrição dos genes presentes no microbioma dos solos de manguezais. Os resultados dessas análises são apresentados nas seguintes publicações:

Taketani, RG; Yoshiura, CA; Dias, ACF; Andreote, FD; Tsai, SM. Diversity and identification of methanogenic archaea and sulphate-reducing bacteria in sediments from a pristine tropical mangrove. Antonie van Leeuwenhoek, v. 97, p. 401-411, 2010. (Doc. VII-1.22)

Dias, ACF; Dini-Andreote, F; Taketani, RG; Tsai, SM; Azevedo, JL; Melo, IS; Andreote, FD. Archaeal communities in the sediments of three contrasting mangroves. Journal of Soils and Sediments, v. 11, p. 1466-1476, 2011. (Doc. VII-1.28)

Andreote, FD; Jimenez, DJ; Chaves, D; Dias, ACF; Luvizotto, DM; Dini-Andreote, F; Fasanella, CC; Baena, S; Lopez, MV; Taketani, RG; Melo, IS. The microbiome of Brazilian mangrove sediments as revealed by metagenomics. Plos One, v. 7, p. e38600, 2012. (Doc. VII-1.42)

Dias, ACF; Pereira e Silva, MDC; Cotta, SR; Dini-Andreote, F; Soares Jr, FL; Salles, JF; Azevedo, $J L$; van Elsas, JD; Andreote, FD. Abundance and genetic diversity of nifH gene sequences in anthropogenically affected Brazilian mangrove sediments. Applied and Environmental Microbiology, v. 78, p. 7960-7967, 2012. (Doc. VII-1.43)

Varon-Lopez, M; Dias, ACF; Fasanella, CC; Durrer, A; Melo, IS; Kuramae, EE; Andreote, FD. Sulphur-oxidising and sulphate-reducing communities in Brazilian mangrove sediments. Environmental Microbiology, v. 16, p. 845-855, 2014. (Doc. VII-1.59)

Armando Cavalcante Franco Dias. Diversidade de arquéias e bactérias envolvidas na ciclagem do nitrogênio em sedimentos de manguezais. 2012. Doutorado em Biologia na Agricultura e no 
Ambiente, Centro de Energia Nuclear na Agricultura - USP. Bolsista FAPESP. Co-orientador.

(Doc. XI.1.1.1)

De maneira geral, as análises por meio de comparação dos perfis de bandas, nas análises de PCR-DGGE, dos genes relacionados a funções especificas, revelaram a diferenciação destas comunidades de acordo com o histórico de preservação dos manguezais (Figura II.7). A única exceção está na análise do gene $a m o A$ de arquéias, a qual mostrou-se muito similar em todos os manguezais estudados (DIAS et al., 2011). A baixa distinção para os perfis de bandas obtidos, bem como o pequeno número de bandas presentes nesta análise, podem estar relacionados com a baixa aerobiose nos solos de manguezais, o que limita a ocorrência do processo de oxidação da amônia.

Os demais genes (nifH, dsrB e aprA) mostraram-se responsivos a contaminação, seguindo os mesmos padrões observados para as análises baseadas em genes ribossomais (DIAS et al., 2012; VARON-LOPEZ et al., 2014). Isto pode indicar que grupos microbianos que hospedam tais genes têm suas frequências relativas alteradas de acordo com alterações no ecossistema, ou que tais genes podem ser mais amplamente distribuídos, por exemplo via transferência horizontal de genes (THG), quanto da ocorrência de condições ambientais diferenciadas (promovidas pela contaminação). Apesar de a primeira possibilidade ser a mais provável, sabe-se que muitos genes relacionados a funções específicas são passíveis de serem adquiridos via THG, e o papel deste processo na evolução microbiana em ambientes complexos ainda é pouco explorado. 
(a)
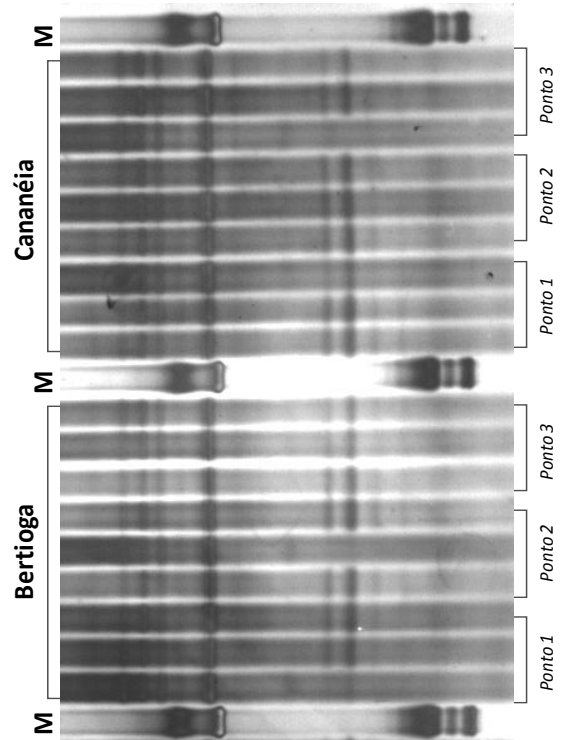

(c)
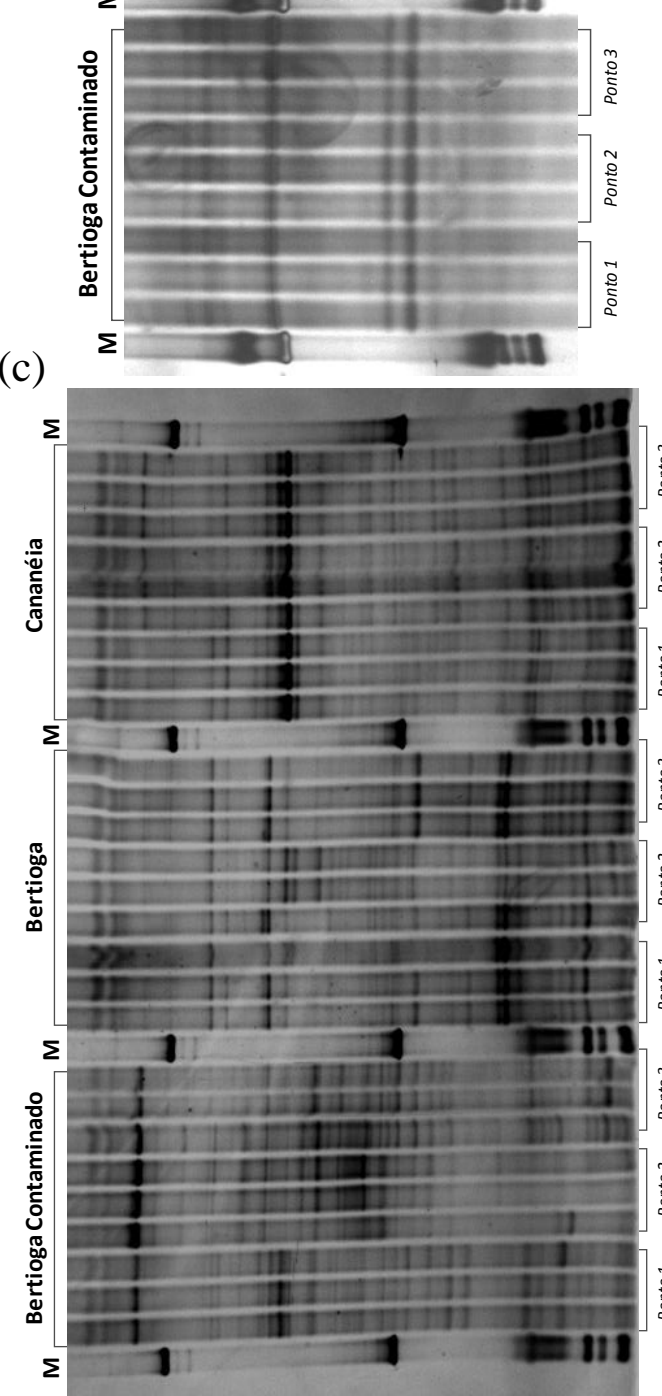

(b)*

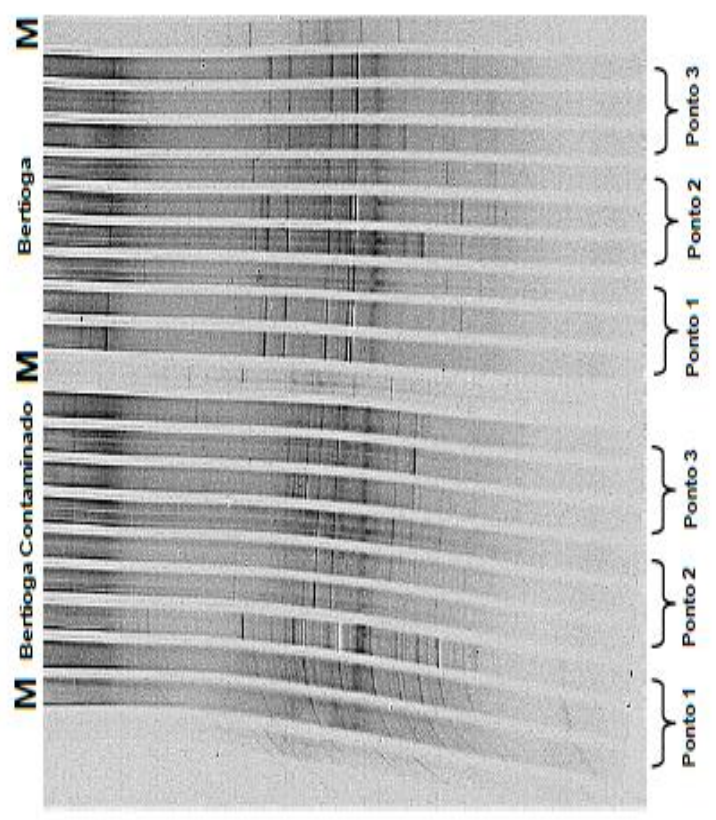

(d)

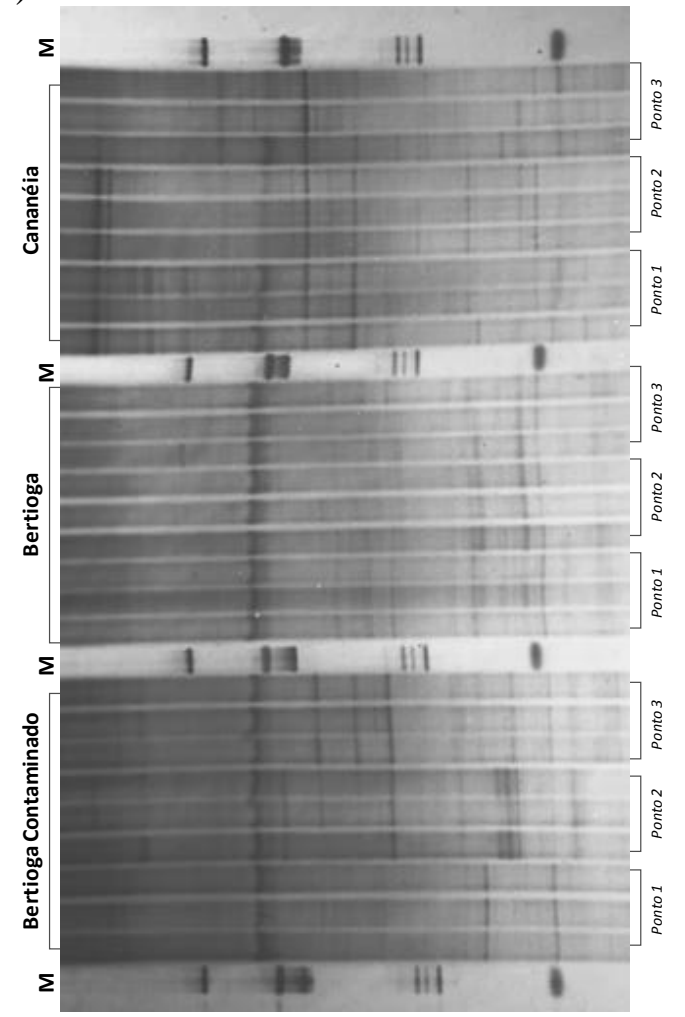

Figura II.7. Comparação das comunidades microbianas por meio de PCR-DGGE com base nos genes amoA de arquéias (a), nifH (b), $d s r B$ (c) e $\operatorname{aprA}(\mathrm{d})$.*a análise de nifH foi realizada apenas nos manguezais de Bertioga. Fontes: DIAS et al., (2011); DIAS et al, 2012, VARON-LOPEZ et al. (2014). 
Um outro ponto de destaque nestas análises é a frequente observação de sequências com baixa similaridade àquelas já presentes em bancos de dados. Tais sequências são classificadas como o gene alvo, no entanto quando comparadas em análises filogenéticas, se agrupam separadamente das demais. Esta observação foi feita para os genes amoA de arquéias, nifH, $d s r B$ e aprA (DIAS et al., 2011; DIAS et al., 2012; VARON-LOPEZ et al., 2014), o que corrobora os dados de afiliação taxonômica dos isolados de Planctomycetes, apresentados acima. Este tipo de observação sugere a ocorrência de grupos endêmicos nos solos de manguezais, com estrutura protéica, e possivelmente funcionamento, distintos daqueles observados em organismos similares encontrados em outros ambientes.

Este tipo de observação é corroborado na análise das sequências geradas por metagenômica (sequenciamento direto do DNA do solo), onde apenas uma pequena quantidade das sequências obtidas encontra similaridade com àquelas já depositadas nos bancos de dados. Esta quantidade é menor do que a comumente afiliada a funções conhecidas em outros metagenomas, variando entre 27 e 33\% do total. Para este tipo de análise (metagenômica), apenas quatro amostras foram consideradas, seguindo as preposições e o esquema apresentado no trabalho de Andreote et al. (2012).

A análise de metagenômica supriu dados para preencher diversas lacunas, as quais eram ainda desconhecidas nos solos de manguezais. Inicialmente, esta análise definiu a composição taxonômica dos organismos presentes no ambiente (mais robustamente para bactérias). Adicionalmente, devido a possibilidade de se realizar a reconstrução metabólica do ambiente, foi possível observar a ocorrência da base genética para os ciclos biogeoquímicos, sendo ainda relacionada a abundância de genes específicos a intensidade em que cada transformação supostamente ocorre nestes solos. Foram reconstruídos com este intuito, os metabolismos relacionados com as ciclagens de carbono (com enfoque em metano), nitrogênio e enxofre (Figura II.8).

$\mathrm{Na}$ análise das transformações de carbono, a presença de quase todos os passos para a assimilação de metano foi observada. Da mesma forma, na ciclagem do nitrogênio, observou-se a presença de sequências afiliadas aquelas relacionadas a fixação biológica do nitrogênio, e sequências relacionadas às transformações do nitrato, seja via desnitrificação ou pela redução dissimilatória do nitrato. Em relação às transformações do enxofre, a maior abundância de sequências é observada nas etapas relacionadas à redução do sulfato (Figura II.8).

Sabendo que os genes associados a ciclagem biogeoquímica de carbono, nitrogênio e enxofre estão presentes nos manguezais e que os organismos que realizam essa função são 
na maioria dos casos endêmicos, a próxima etapa consiste na avaliação do perfil da expressão de genes por meio da técnica de metatranscriptômica e na compreensão do contexto genômico dessas comunidades.

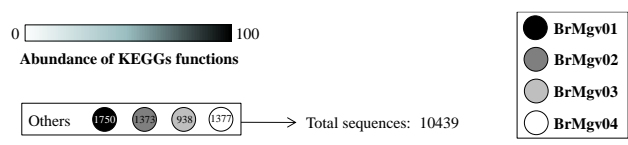

(a)

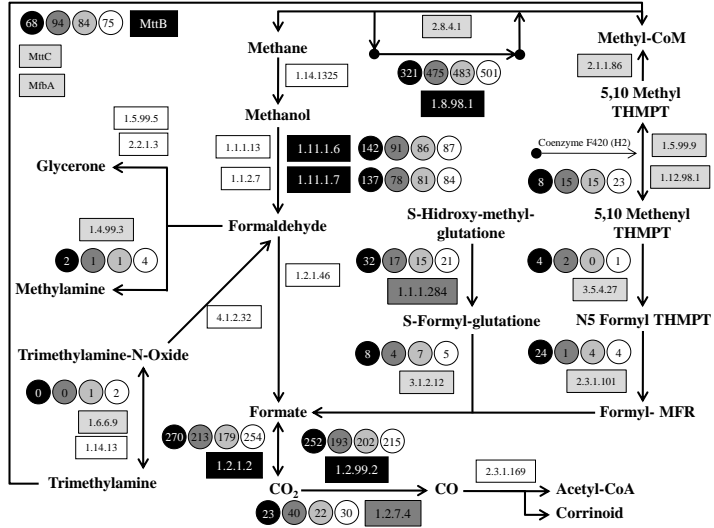

Others (144) (898) (850)

(b)

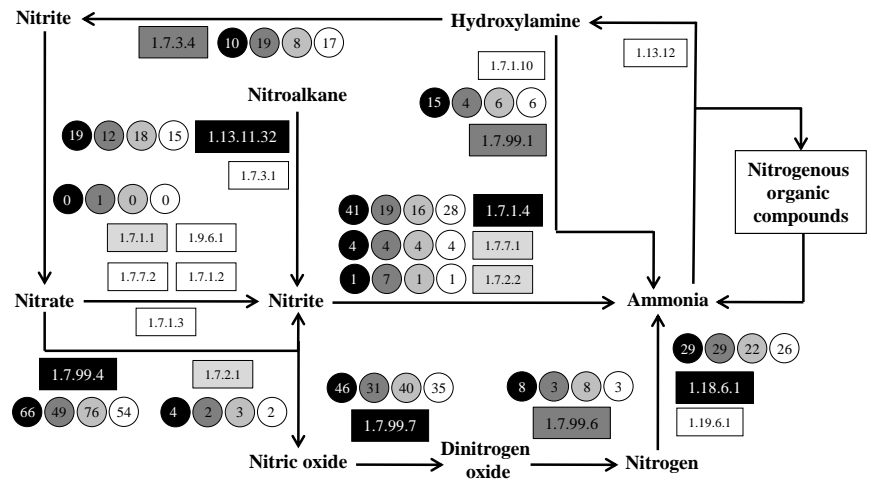

\begin{tabular}{|llll}
\hline Others 84 & 43 & 40 & $\longrightarrow$
\end{tabular} Total sequences: 1335

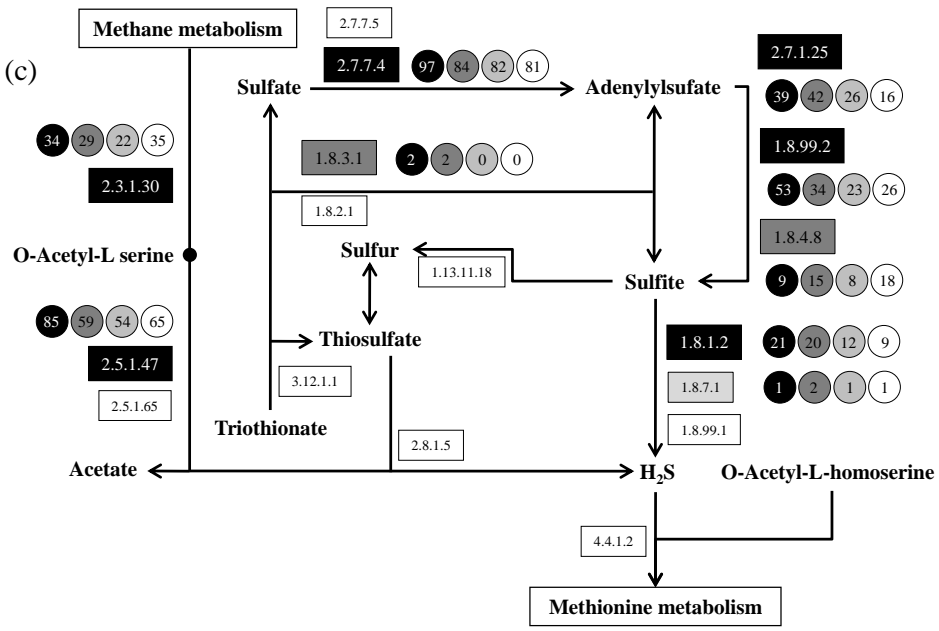

Figura II.8. Reconstrução metabólica das transformações do carbono (a), nitrogênio (b) e enxofre (c), em solos de manguezais sob distintos estágios de preservação. A intensidade das cores nos quadrados mostra a abundância no número de sequências afiliadas a esta função KEGG Fonte: ANDREOTE et al. (2012). 
No sentido de aproximar cada vez mais os resultados obtidos aos real funcionamento do microbioma dos manguezais, está em desenvolvimento a análise de metatranscriptômica, onde o RNA extraído diretamente dos solos foi sequenciado, gerando uma quantidade enorme de informação (283,94 milhões de sequências, distribuídas em datasets de RNAtotal e RNAm purificado). Comparando os resultados com os obtidos na análise DNA é possível observar a partir de dados iniciais de análises, que os genes previamente descritos como presentes nos manguezais, pela metodologia de metagenômicas, estão sendo encontrados como expressos na análise de metatranscriptômica. Esta informação indica que pode ocorrer uma alta ciclagem da biomassa neste ambiente, sendo os organismos e genes presentes, aproveitados de forma intensa para o funcionamento do ecossistema. Em relação entre as similaridades entre as composições taxonômicas e funcionais do microbioma dos manguezais estudados, é possível verificar que as amostras de manguezais distintos se separam taxonomicamente com base na análise do DNA, enquanto que a metatranscriptômica leva a melhores separações dos manguezais com base na análise funcional (com destaque para análise com RNA purificado) (Figura II.9).

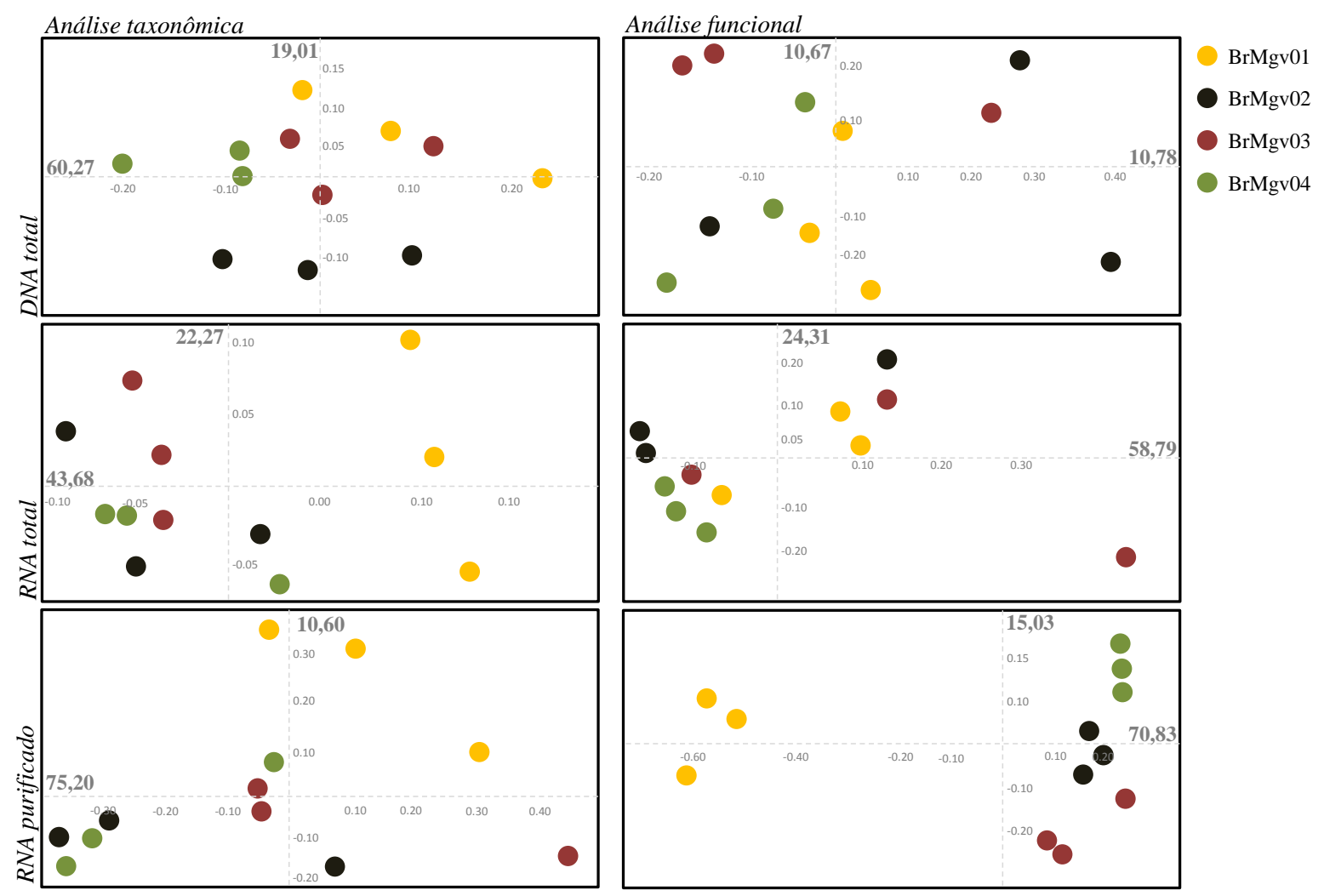

Figura II.9. Análises de PCoA para a comparação do perfil taxonômicos e funcional das comunidades microbianas, com base na informação contida no DNA e no RNA obtidos diretamente de amostras de solo. Os valores nos eixos indicam a porcentagem da variância explicada pelos mesmos. Figura inédita. 
Outro tópico que merece atenção é a descrição da organização genômica em que os genes de interesse ocorrem em organismos presentes em solos de manguezais, o que pode elucidar o endemismo e adicionar informações a baixa identidade observada entre os genes e proteínas do microbioma de manguezal com os encontrados em bancos de dados internacionais. Para isso, um novo tipo de análise está sendo realizado em nosso grupo, onde uma biblioteca de fosmídeos construída a partir de fragmentos de DNA dos manguezais está sendo estudada.

Os insertos fosmidiais que hospedam os operons nif e $d s r$, relacionados a fixação biológica do nitrogênio e redução do sulfato, respectivamente, estão sendo sequenciados para fornecer mais detalhes sobre a organização e contexto genômico em que tais genes ocorrem. Os primeiros resultados indicam que nos fosmídeos que apresentam o operon $d s r$ (dois fosmídeos sequenciados 23D5 e 40E4), foram identificadas proteínas diretamente envolvidas na redução dissimilatória de sulfato/sulfito, como genes que codificam transportadores de sulfato (aprAB), transportadores de elétrons $(h d r)$ e redução dissimilatoria de sulfito ( $d s r \mathrm{AB})$ (Figura II.10). A afiliação de tais fragmentos genômicos está sendo aprimorada, sendo inicialmente usado como marcador o gene $d s r \mathrm{AB}$, que revelou similaridade com as sequências oriundas de organismos afiliados ao filo Firmicutes (clone 40E4) e a classe Deltaproteobacteria (clone 23D5). No entanto, a similaridade das sequências destes genes foi baixa (64 e 65\%, respectivamente), indicando novamente a possível ocorrência de endemismo nos complexos enzimático que foram selecionados dentro dos solos de manguezais.

Fosmideo 23D5

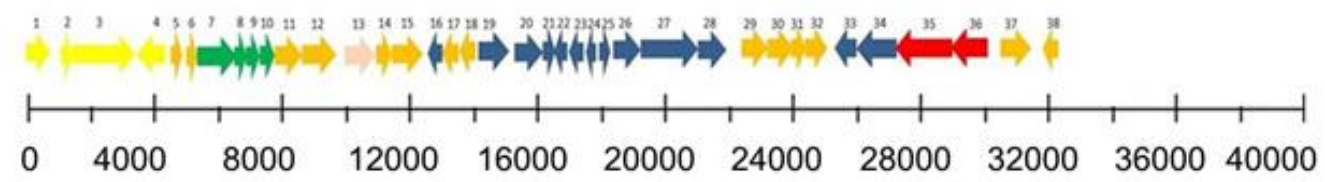

Fosmideo 40E4

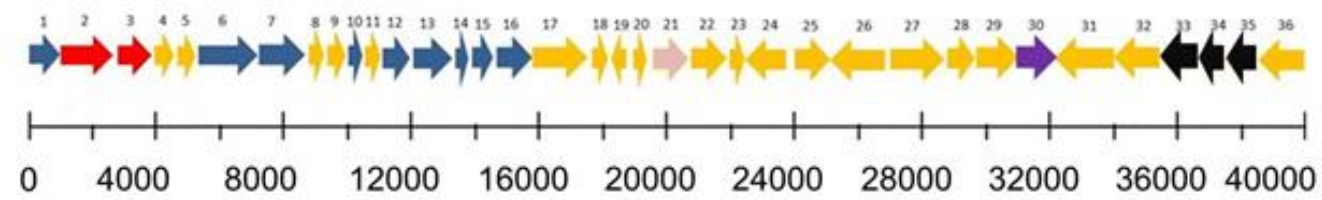

Figura II.10. Ocorrência do operon $d s r$ em fragmentos genômicos obtidos de solos de manguezais. Genes relacionados com o metabolismo do enxofre estão apresentados por setas azuis, com exceção para os genes $d s r \mathrm{~A}$ e $d s r \mathrm{~B}$, representados por setas vermelhas. 


\section{II.3.3. Quantificação de grupos microbianos em solos de manguezais}

Conjuntamente a determinação da estrutura das comunidades microbianas e à distribuição de genes, faz-se essencial inferir sobre a abundância desses organismos nos solos dos manguezais estudados. Assim sendo, grupos taxonômicos e funcionais foram alvos de quantificação, sendo estas análises realizadas com base na metodologia de PCR quantitativo em tempo real (Tabela II.1).

Observa-se nos resultados de quantificação que bactérias e arquéias são mais abundantes, e menos responsivos a alterações nas condições dos manguezais. Os fungos por sua vez, apresentam um aumento em abundância nas áreas com maior contaminação por petróleo, atingindo uma unidade logarítmica a mais do que nas demais áreas. Este tipo de resultado pode evidenciar o papel dos mesmos na degradação deste tipo de contaminante ambiental nos manguezais (Tabela II.1).

Tabela II.1. Quantificação de grupos taxonômicos e funcionais microbianos nos solos dos manguezais estudados na linha litorânea do Estado de São Paulo. Valores apresentados em log do número de copias do gene alvo por grama de solo, seguidos dos valores de desvio padrão (entre parênteses) Fontes: DIAS et al., (2012); DIAS, (2012); FASANELLA et al. (2012); VARON-LOPEZ et al. (2014).

\begin{tabular}{ccccccc}
\hline Manguezais & 16S DNAr & 16S DNAr & ITS & nifH & dsrB & aprA \\
& Bactérias & Arqueias & Fungos & & & \\
\hline OilMgv & & & & & & \\
Ponto 1 & $9.96(0.11)$ & $8.90(0.55)$ & $7.83(0.10)$ & $6.81(0.54)$ & $5.07(0.08)$ & $5.52(0.04)$ \\
Ponto 2 & $10.4(0.01)$ & $9.57(0.08)$ & $9.18(0.11)$ & $7.26(0.26)$ & $5.31(0.04)$ & $5.50(0.11)$ \\
Ponto 3 & $10.4(0.03)$ & $9.78(0.15)$ & $8.53(0.15)$ & $7.22(0.21)$ & $5.17(0.13)$ & $5.23(0.10)$ \\
AntMgv & & & & & & \\
Ponto 1 & $10.2(0.07)$ & $8.99(0.41)$ & $7.63(0.07)$ & $7.40(0.05)$ & $5.04(0.08)$ & $5.67(0.14)$ \\
Ponto 2 & $10.3(0.12)$ & $9.43(0.25)$ & $7.51(0.18)$ & $6.88(0.07)$ & $4.87(0.29)$ & $5.54(0.18)$ \\
Ponto 3 & ND & $8.89(0.18)$ & $7.59(0.12)$ & $6.87(0.19)$ & $5.02(0.08)$ & $5.63(0.05)$ \\
PrsMgv & & & & & & \\
Ponto 1 & $9.66(0.16)$ & $9.41(0.07)$ & $7.65(0.11)$ & ND & $5.22(0.30)$ & $5.63(0.17)$ \\
Ponto 2 & $9.70(0.06)$ & $8.93(0.07)$ & $8.31(0.12)$ & ND & $5.11(0.25)$ & $5.58(0.05)$ \\
Ponto 3 & ND & $9.37(0.09)$ & $8.09(0.19)$ & ND & $5.04(0.21)$ & $5.00(0.54)$ \\
\hline ND - Não determinado & & & & &
\end{tabular}


Quando a quantificação é realizada para os genes relacionados a processos específicos, esta diferenciação aparece tanto na quantificação total, como na relação encontrada entre as quantidades de genes distintos. O exemplo mais claro do efeito da contaminação em tal proporcionalidade ocorre nos genes relacionados às transformações do enxofre ( $d s r B$ e $a p r A)$. Apesar das quantificações de tais genes não serem claramente alteradas no manguezal OilMgv, a razão dsrB/aprA demonstra claramente o efeito deste evento sobre a comunidade que os hospeda (Figura II.11). Nota-se que esta razão aumenta de acordo com o incremento na contaminação do manguezal OilMgv (menor no ponto 1 e maior no ponto 3). Nos demais manguezais, onde este gradiente de contaminação não ocorre, a razão entre as quantidades destes genes apresenta-se homogênea ao longo de todo o transecto estudado (VARON-LOPEZ et al., 2014).

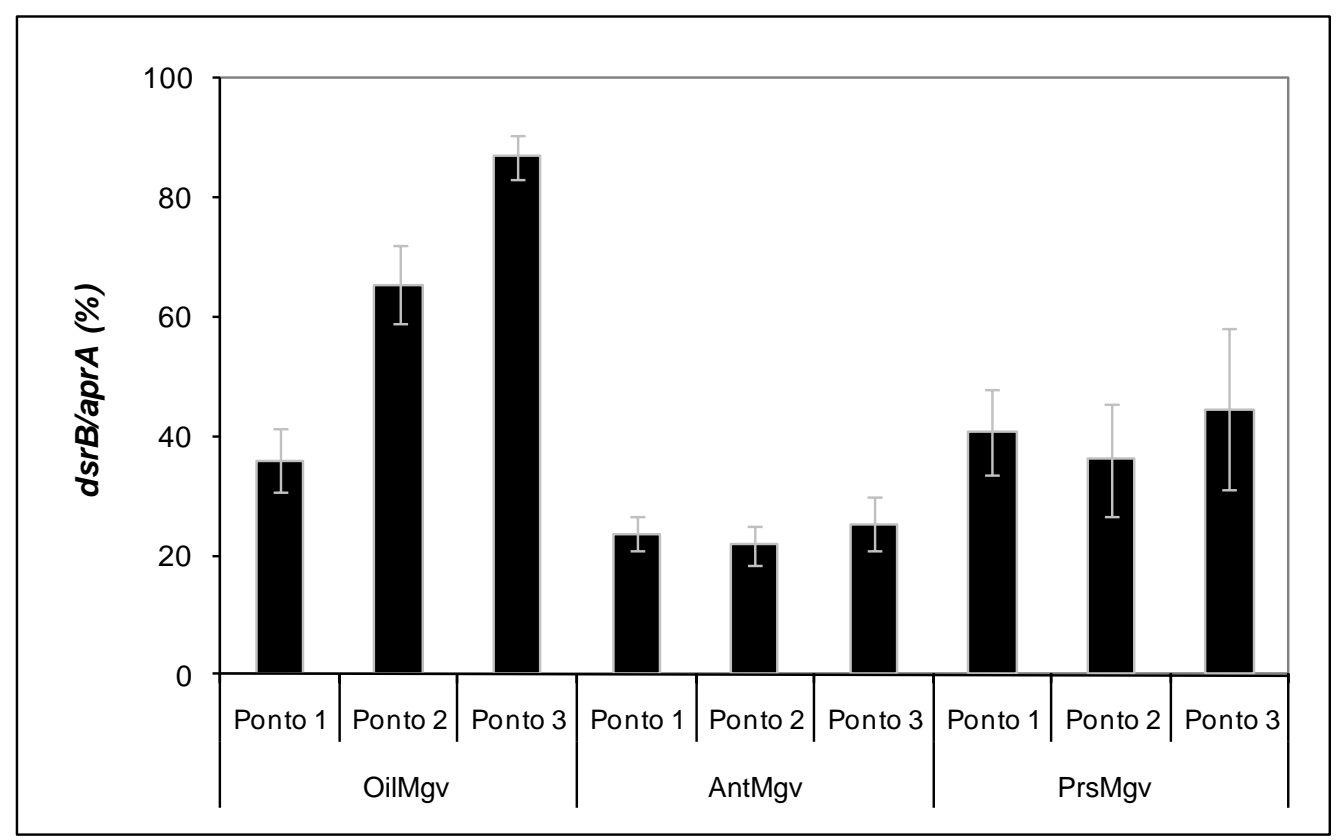

Figura II.11. Razão entre as quantidades dos genes $d s r B$ e aprA nos solos de manguezais do Estado de São Paulo sob distintos estágios de conservação. Fonte: VARONLOPEZ et al. (2014).

\section{II.3.4. Exploração biotecnológica de grupos microbianos de solos de manguezais}

Além de justificar-se pela necessidade de um melhor conhecimento sobre este ambiente ainda pouco explorado, o estudo do microbioma de solos de manguezais mostra-se importante na bioprospecção de novas enzimas e moléculas com potencial biotecnológico. Considerando as condições ambientais únicas encontradas nesses solos, e a possível ocorrência de grupos e genes endêmicos neste ambiente, a identificação de compostos ativos 
mostra-se altamente promissora. Apesar desta não ser a área de maior atuação do candidato, alguns trabalhos foram desenvolvidos nesta linha de pesquisa:

Dias, ACF; Andreote, FD; Dini-Andreote, F; Lacava, PT; Sá, ALB; Melo, IS; Azevedo, JL; Araújo, WL. Diversity and biotechnological potential of culturable bacteria from Brazilian mangrove sediment. World Journal of Microbiology and Biotechnology, v. 25, p. 1305 - 1311, 2009. (Doc. VII-1.15)

Fábio Lino Soares Júnior. Isolamento e caracterização de bactérias celulolíticas de ambientes extremos. 2011. Mestrado em Biotecnologia, Universidade de São Paulo. Sem bolsa. (Doc. XI.1.2.1)

Soares Jr, FL; Dias, ACF; Fasanella, CC; Taketani, RG; Lima, AOS; Melo, IS. Endo- and exoglucanase activities in bacteria from mangrove sediment. Brazilian Journal of Microbiology, v. 44, p. 696-976, 2013 (Doc. VII.1.55).

Inicialmente, os trabalhos foram embasados na exploração de isolados bacterianos, os quais foram caracterizados quanto a sua capacidade de produzir diversas enzimas como amilases, esterases, proteases e lipases (DIAS et al., 2009). Acredita-se que sendo os solos de manguezais ricos em matéria orgânica (devido a baixa oxigenação), se encontra sob constante processo de mineralização, sendo este processo promovido pela atividade conjunta de diversos organismos altamente adaptados.

Mais detalhadamente, a produção de enzimas relacionadas a degradação da celulose, como as endoglucanases e exoglucanases foram observadas em isolados bacterianos provenientes dos solos do manguezal localizado na cidade de Cananéia (PrsMgv). Estes isolados mostraram a produção dessas enzimas, e a atividade destas mostrou-se regulada pela adição de sal ao meio de cultivo (Figura II.12), o que indica sua adaptação as condições ambientais presentes no solo estudado. Os isolados foram identificados, sendo os grupos mais amplamente representados como aqueles pertencentes aos grupos Alphaproteobacteria, Gammaproteobacteria, Actinobacteria, Firmicutes e Bacteroidetes (SOARES Jr. et al., 2013). 


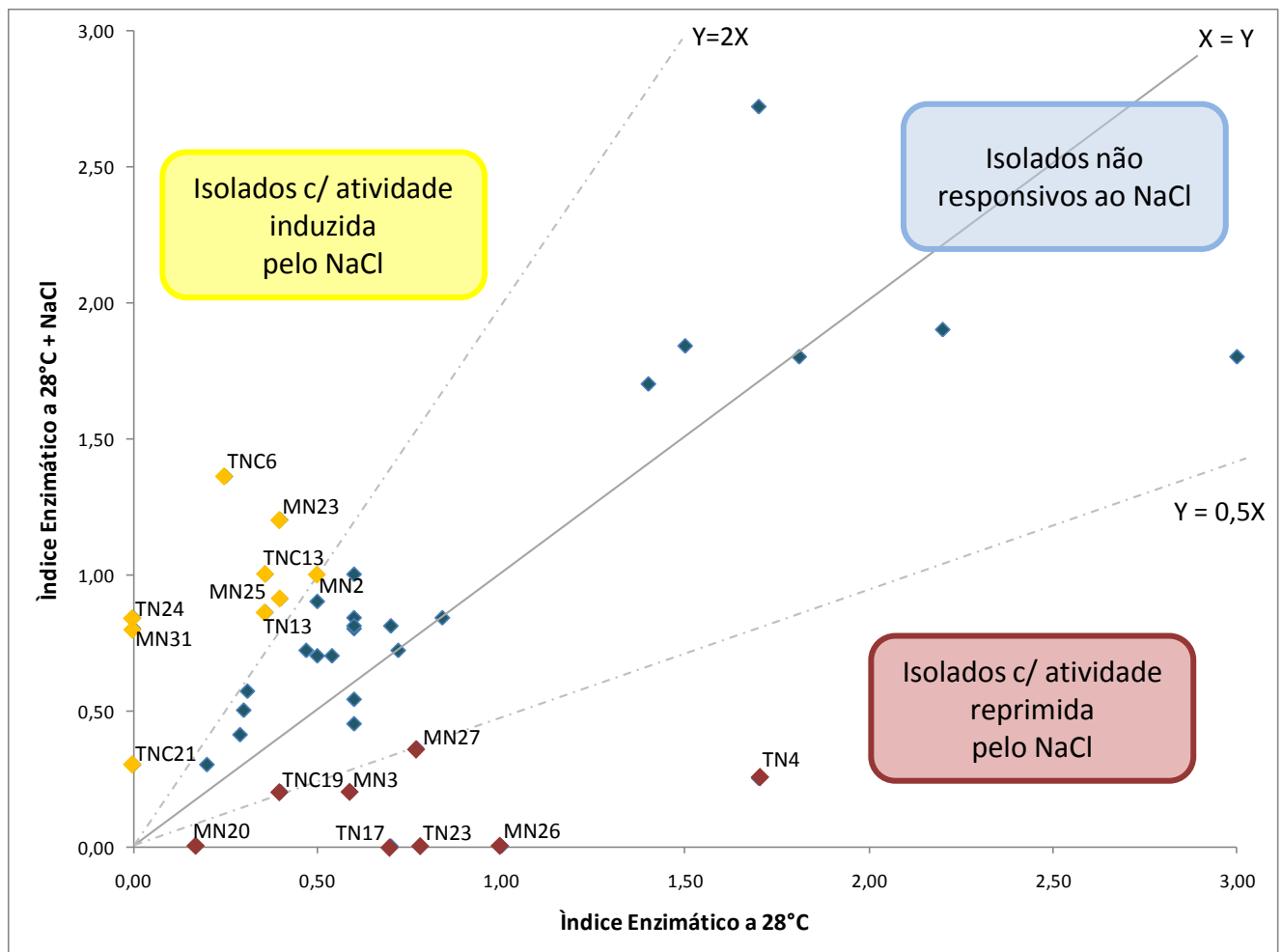

Figura II.12. Atividade endoglicolítica dos isolados bacterianos isolados de manguezais em diferentes condições de salinidade. $O$ índice enzimático foi determinado pela razão entre o diâmetro do halo de degradação do substrato (carboxi-metilcelulose) e o diâmetro da colônia bacteriana. Fonte: SOARES Jr. et al. (2013).

Com a finalidade de aprimorar estas análises, outros trabalhos estão sendo conduzidos, embasados na exploração de uma biblioteca metagenômica, onde busca-se identificar genes relacionados a enzimas envolvidas na degradação da matéria orgânica nos solos de manguezais. Estão sendo estudadas sequências gênicas codificadoras de celulases e xilanases, sendo os resultados iniciais bastante promissores devido a baixa identidade das sequências observadas com aquelas disponíveis em bancos de dados. Estes estudos estão ainda em desenvolvimento, mas um exemplo deste tipo de análise é apresentado na figura II.13. 


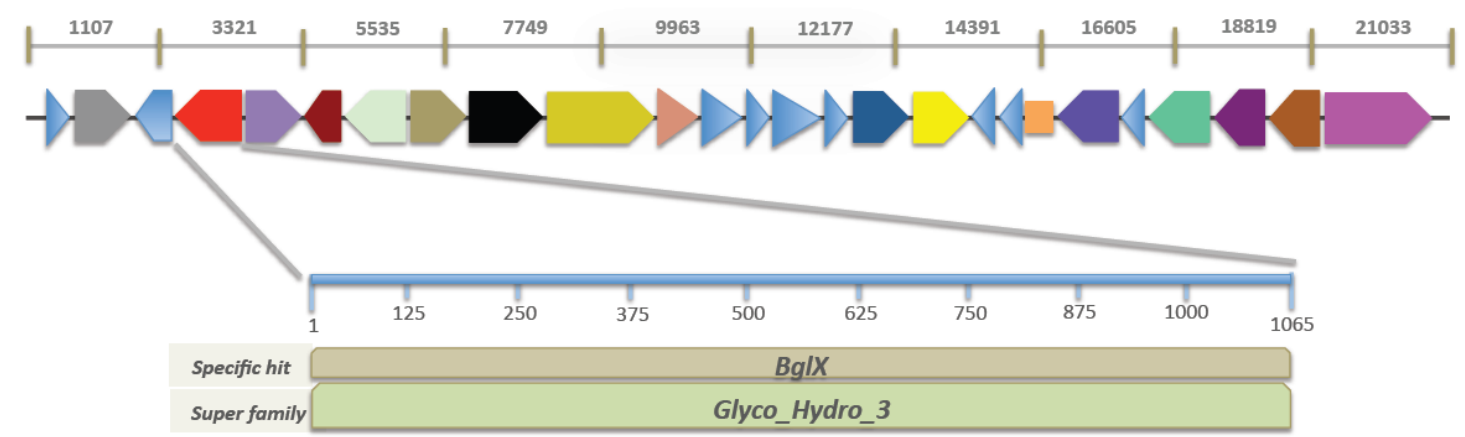

Figura II.13. Anotação dos genes contidos em um inserto fosmidial com atividade para a degradação de carboxi-metil-celulose (evidenciando seu potencial endoglicolítico). $\mathrm{O}$ gene identificado como responsável pela atividade tem identidade de 37,98\% com uma $\beta$-N-Acetylhexosaminidase de Desulfococcus oleovorans (Deltaproteobacteria). Figura inédita.

\section{II.4. PeRSPECTIVAS FUTURAS PARA O ESTUdO DO MICROBIOMA DE SOLOS DE MANGUEZAiS}

Dentre os mais diversos ambientes alvos de estudos microbiológicos, àqueles que apresentam características particulares são os mais promissores na descrição de novos grupos microbianos, novos processos metabólicos, e mesmo novas organizações genômicas, que podem combinar taxonomia e função de forma particular para cada um dos ecossistemas explorados.

Os manguezais, além de apresentarem a combinação de condições ambientais únicas, são por vezes considerados um ambiente intermediário entre os ambientes chamados de comuns ou extremos. Este posicionamento na escala de inospitalidade (exclusivamente definida a partir de uma visão antropocêntrica), torna os manguezais altamente promissores em relação a descrição e a exploração biotecnológica do microbioma presente em seus solos. Somado a isto, a frequente contaminação deste ambiente, levanta a necessidade de se entender os efeitos da entrada dos materiais indesejados neste sistema, dando base a estratégias inovadoras de recuperação destas áreas.

Sobre este cenário, o candidato vem desenvolvendo a linha de estudo apresentada nesta sessão, e tem como perspectiva a conclusão de algumas destas etapas, e o início de algumas outras, que visam complementar o conjunto de informações já levantadas nas áreas alvos de estudo. Num primeiro momento, percebe-se a necessidade de finalização de alguns trabalhos, principalmente os relacionados a análise de metatranscriptômica, e os trabalhos de caracterização biotecnológica dos recursos microbianos presentes nestes solos. 
Alguns outros estudos deverão envolver outras etapas de trabalho para sua finalização, como o estudo de Planctomycetes, que deverá ser concluído com o sequenciamento dos genomas dos isolados obtidos. Este tipo de resultado deverá ser somado aos demais para o melhor entendimento sobre a ocorrência de grupos microbianos endêmicos ao ambiente de manguezais. Com o sucesso deste tipo de análise, possivelmente outros grupos microbianos deverão ser alvos de estudos mais detalhados, com destaque para os pertencentes a classe Deltaproteobacteria, grupo mais abundante neste solo.

A estruturação dos genomas destes grupos deverá indicar a ocorrência de um processo de grande importância, porém ainda inexplorado nos solos de manguezais, a ocorrência e a funcionalidade de elementos móveis. Um estudo está sendo iniciado com este enfoque, uma vez que tanto na análise de metagenômica como na metatranscriptômica observa-se uma grande quantidade de sequências afiliadas a estas estruturas (dados iniciais não apresentados neste documento). Assim sendo, uma vez que são presentes e funcionais, o papel destes elementos deve ser grande, tanto na evolução do microbioma presente nestes solos, quanto na resposta do mesmo a diferentes processos de contaminação ambiental.

Uma outra vontade do candidato está na análise combinada dos resultados já obtidos com aqueles oriundos de outros grupos de pesquisa no Brasil e no exterior. Como os dados apresentados nesta sessão são referentes a manguezais localizados na linha costeira do Estado de São Paulo, é de extrema importância integrar os mesmos com os dados de outros grupos que estudam o mesmo ambiente em outros Estados brasileiros, ou em outras regiões do mundo em que este ambiente ocorre.

Os solos de manguezais são altamente atrativos do ponto de vista científico e tecnológico, sendo os estudos realizados neste ambiente, sempre inovadores, e tendo como um dos maiores resultados, o levantamento de uma série de novas questões a serem respondidas. 


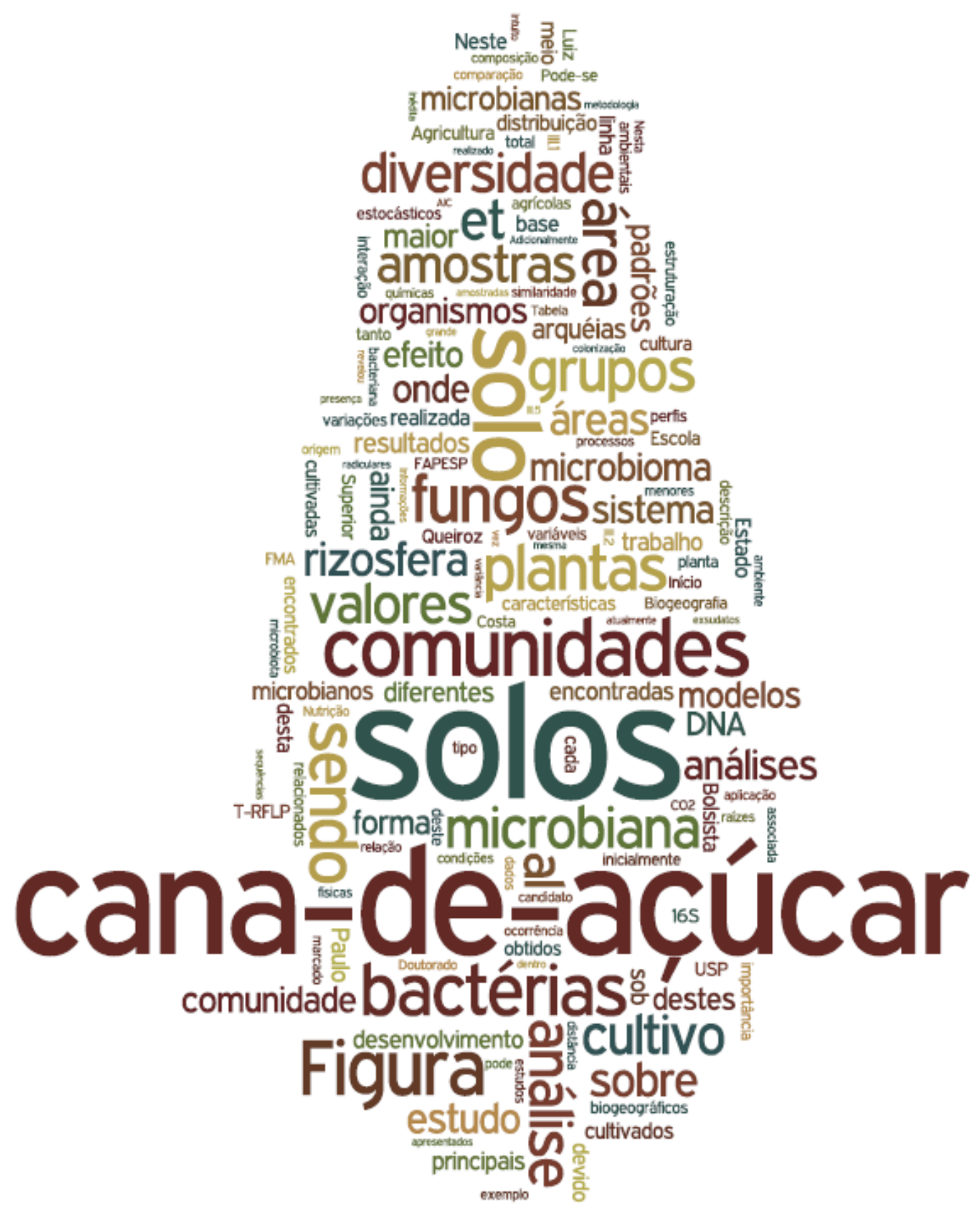

Sessão III

MICROBIOMA DE SOLOS CULTIVADOS COM CANA-DE-AÇÚCAR 


\section{SESSÃO III - MiCROBIOMA DE SOLOS CULTIVADOS COM CANA-DE-AÇÚCAR}

Esta sessão é a de maior expansão desde o início das atividades do candidato como docente da Universidade de São Paulo. Serão apresentadas inicialmente informações adicionais sobre os solos usados para o cultivo de plantas, e posteriormente serão enumeradas as contribuições do candidato no conhecimento do microbioma dos solos cultivados com canade-açúcar. Esta escolha se dá devido a localização estratégica da Universidade e a importância econômica desta cultura.

\section{III.1. IMPORTÂNCIA DA CANA-DE-AÇÚCAR E AS MUDANÇAS NO SISTEMA PRODUTIVO}

O Brasil é o maior produtor mundial de cana-de-açúcar, sendo os seus principais derivados o álcool e o açúcar. O Estado de São Paulo apresenta atualmente algo em torno de 54\% da área cultivada com cana-de-açúcar no Brasil, com aproximadamente 4,36 milhões de hectares plantados (Figura III.1) (CONAB, 2011). A importância econômica e social da cultura da cana-de-açúcar é elevada, gerando mais de 610 mil empregos de forma direta e 930 mil de forma indireta (ROSSETTO, 2008). Este mercado é crescente, principalmente devido ao aumento da demanda dos principais produtos oriundos desta cultura (etanol e açúcar). Para atender esta demanda, o setor sucro-alcoleiro tem duas alternativas; o aumento na produtividade, ou a expansão das fronteiras agrícolas. Uma vez que a segunda alternativa é menos desejável, por causar impacto sobre a área ocupada por outras culturas, ou então a utilização de áreas sob vegetação natural, a busca por uma maior produtividade torna-se bastante atual na cultura de cana-de-açúcar no Brasil.

A demanda por uma maior produtividade apresenta-se juntamente com um cenário de mudanças no manejo da cultura da cana-de-açúcar. Recentemente, devido a proibição da queimada da palhada da cana-de-açúcar, o sistema produtivo vem enfrentando novos desafios. O primeiro grande desafio se apresenta na alteração do sistema de colheita da canade-açúcar, que atualmente é realizado de forma mecanizada. Este sistema é mais rápido e homogêneo, porém acarreta em uma maior compactação dos solos, fato pouco expressivo no sistema de cultivo anterior (ALVIM et al., 2004; VITTI et al., 2007; GALDOS et al., 2010). Outra grande questão está no efeito da palhada que fica sobre os solo após a colheita, sendo ampla a discussão que envolve o uso deste material para queima e geração de energia, ou na manutenção desta grande quantidade de matéria orgânica sobre o solo, onde esta atua 
de forma benéfica (FRANCO et al., 2007; VITTI et al., 2007). Estas questões estão para serem respondidas, sendo necessário o desenvolvimento de estudos detalhados, que envolvam as diferentes variáveis relacionadas ao sistema de cultivo.

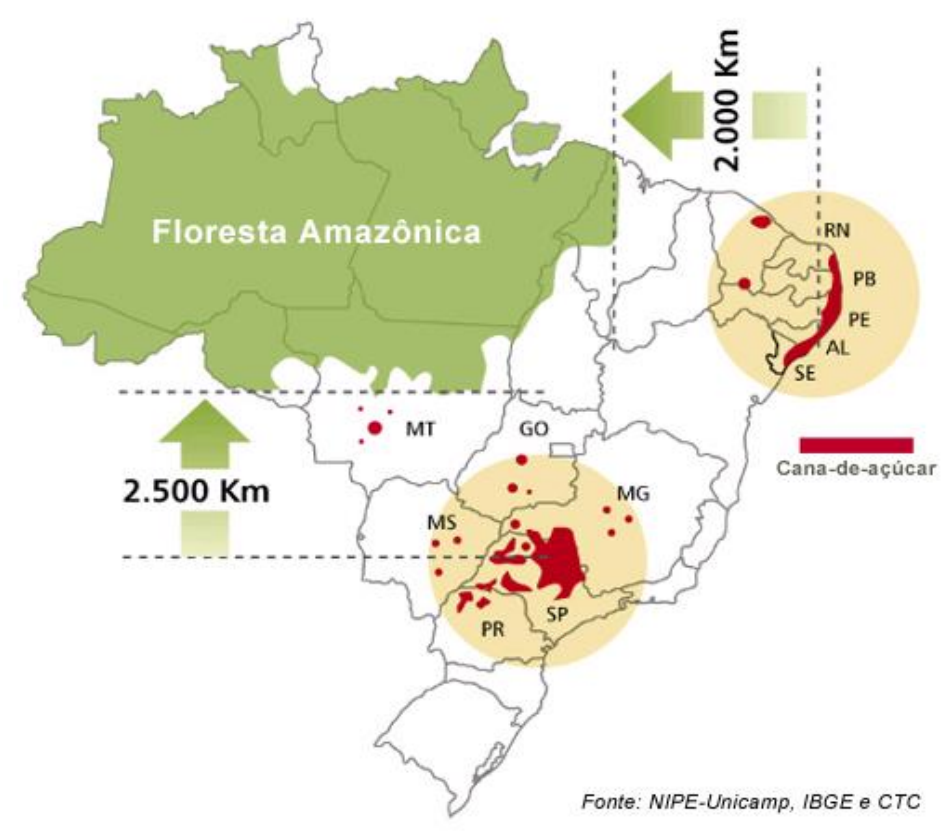

Figura III.1. Áreas de cultivo de cana-de-açúcar no Brasil. Fonte: Única (http://www.unica.com.br/mapa-da-producao/)

Dentro deste contexto, acredita-se que um ponto ainda pouco conhecido e explorado de forma otimizada no cultivo de cana-de-açúcar, seja composto pelo microbioma dos solos, que podem ter papel essencial na manutenção da funcionalidade do sistema solo e no desenvolvimento da cultura.

A diversidade microbiana associada a esta cultura tem sido estudada em casos pontuais, envolvendo apenas uma área de produção, não abrangendo grandes áreas amostrais. Esta diversidade já foi descrita em comunidades associadas com a parte aérea das plantas, como endófitos (MENDES et al., 2007; MAGNANI et al., 2010, STUART et al., 2010), ou em associação com as raízes, como os organismos rizosféricos (LUVIZOTTO et al., 2010). Especificamente nos solos sob cultivo de cana-de-açúcar, Dini-Andreote et al. (2010) estudaram os efeitos do cultivo de cana-de-açúcar transgênica, juntamente com o efeito da aplicação de herbicidas, sobre a comunidade bacteriana, constatando a ausência de efeitos destes fatores, mas descrevendo a existência de uma ampla diversidade bacteriana nesses solos. 
Percebe-se portanto, a importância de se realizar estudos mais abrangentes, que sejam desenvolvidos com um maior número de amostras, onde as variáveis sejam melhor relacionadas, e comparadas em diferentes áreas de cultivo. Pode-se ainda sugerir, que a atividade agrícola pode causar a homogeneização do ambiente (RODRIGUES et al., 2013), tornando as condições ambientais sempre propícias ao desenvolvimento vegetal. Portanto, acredita-se que a comunidade microbiana em solos sob mesmo cultivo sejam também partilhadoras de altos níveis de similaridade. Este tipo de efeito, que é resultante tanto da seleção exercida pela planta cultivada, como dos manejos implementados nas áreas agrícolas, pode ser fundamental na interação das plantas com o microbioma do solo.

Para se inferir de forma robusta sobre o efeito do cultivo de cana-de-açúcar sobre as comunidades microbianas dos solos, deve-se colocar esforços na obtenção de respostas básicas sobre o comportamento destes organismos e dos mecanismos de estruturação das comunidades microbianas. Esta necessidade será suprida uma vez que as escalas de estudo forem alteradas, não se focando em algumas plantas ou em poucos talhões, mas migrando para os extremos, por exemplo, buscando entender a ocorrência de padrões biogeográficos em solos sob cultivo de cana-de-açúcar (Box 2), ou na completa descrição do efeito rizosférico dessas plantas sobre a microbiota dos solos.

Adicionalmente, mostra-se necessário correlacionar os estudos de diversidade com a funcionalidade de processos essenciais ao sistema solo, como por exemplo, no entendimento do efeito da alteração da microbiota sobre a interação entre as plantas e fungos micorrízicos. Estas inferências dão base as análises chamadas de 'serviços ambientais promovidos pela biodiversidade', um tema bastante atual e ainda inexplorado em solos agrícolas. 


\section{Box. 2. Biogeografia aplicada à ecologia microbiana}

A ciência se desenvolveu por muitas vezes devido a necessidade de classificar e organizar os organismos, buscando correlacionar dados morfológicos a grupos distintos, bem como as áreas de sua ocorrência. A evolução, com base na seleção natural, conectou estes fatores, gerando a distribuição diferenciada dos organismos vivos de acordo com as diferentes regiões da Terra. A distribuição espacial ou temporal de organismos vivos recebe o nome de biogeografia (LOMOLINO et al., 2006). No entanto, este tipo de estudo tem sido mais amplamente aplicado para estudar e descrever a ocorrência de grupos de animais e plantas, do que para entender a ocorrência e distribuição de células microbianas.

Os maiores desafios relacionados ao estudo biogeográfico de microrganismos podem ser listados como: $i$ ) a longa história evolutivo dos mesmos, e a relativa facilidade em sua disseminação, o que leva a sua elevada taxa de dispersão; $i$ ) os questionamentos sobre a unidade taxonômica em que o processo seletivo ocorre, sendo difícil, na maioria das vezes, englobar organismos oriundos de áreas distintas em uma mesma espécie; iii) as dificuldades relacionadas a representação de populações e comunidades microbianas de forma fiel (recentemente melhorada pelas novas metodologias de estudo); o acesso temporalmente uniforme a organismos similares em diversos ambientes. Todas estas dificuldades estão relacionadas ao rápido ciclo vital microbiano, a ocorrência dos mesmos comumente em comunidades abundantes e diversas, a colonização de ambientes compostos de diversos nichos de colonização, e a sua alta taxa de alteração genética e metabólica, seja esta oriunda de mutações, e ou de eventos de aquisição ou perda de fragmentos de material genético (Figura B2).

Diversos estudos buscam a descrição de padrões biogeográficos em comunidades microbianas, ligando a adaptação de grupos microbianos a características intrínsecas do ambiente explorado. Neste contexto, duas linhas principais de trabalho discutem a biogeografia microbiana (Figura B2). A primeira considera a ocorrência cosmopolita destes organismos, e elege as características ambientais como moduladoras da abundância e composição dos diferentes grupos componentes da comunidade (GREEN AND BOHANNAN, 2006). A segunda hipótese é baseada na ocorrência diferencial de grupos microbianos, sendo esta relacionada ao isolamento geográfico e eventos de especiação (ou distinção de grupos), similarmente ao observado para animais e plantas (CARUSO et al., 2011) (Figura B2). Talvez a real distribuição de microrganismos ocorra de forma combinada entre estas duas teorias, sendo um cenário composto pelo isolamento geográfico em combinação com as condições ambientais, seletivo para ocorrência de comunidades microbianas diferenciadas em cada um dos locais estudados.

Este tipo de estudo é ainda escasso em ambientes de exploração agrícola, onde o manejo empregado, e a homogeneização de grandes áreas, em busca da otimização do desenvolvimento vegetal, exercem pressões únicas, dando oportunidade particular ao entendimento da biogeografia microbiana.

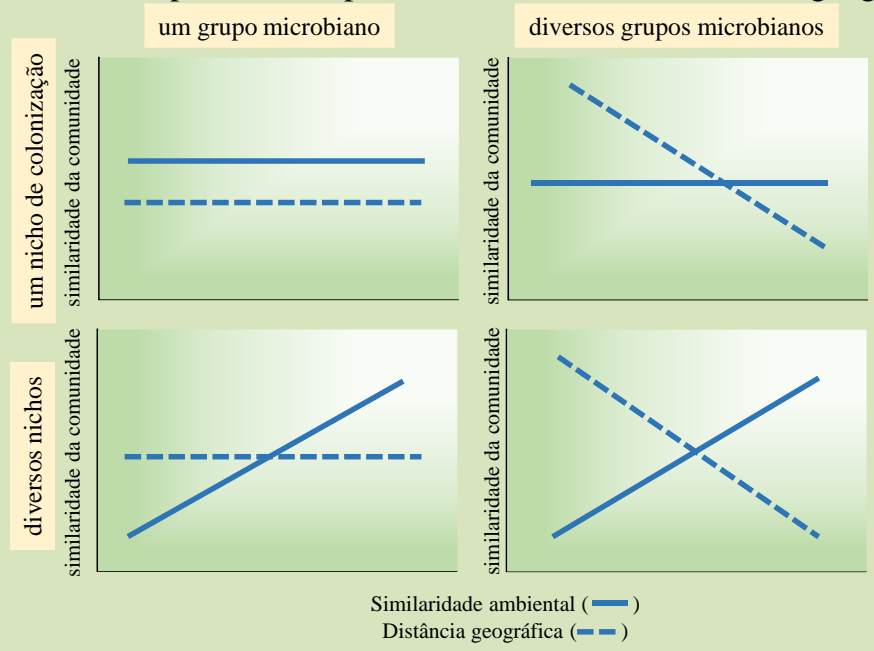

Figura B2. Respostas de grupos microbianos a variações na distância geográfica ou a características ambientais. Adaptado de Martiny et al. (2006)

Caruso T, Chan Y, Lacap D, Lau M (2011) Stochastic and deterministic processes interact in the assembly of desert microbial communities on a global scale. ISME J 5:1406-1413.

Green J, Bohannan BJM (2006) Spatial scaling of microbial biodiversity. Trends Ecol Evol 21:501-507. Lomolino MV, Riddle BR, Brown JH (2006) Biogeography. Sinauer Associates, Sunderland, MA.

Martiny JBH, Bohannan BJM, Brown JH, Colwell RK, Fuhrman J a, et al. (2006) Microbial biogeography: putting microorganisms on the map. Nat Rev Microbiol 4:102-12. 


\section{III.2. CONTRIBUIÇÕES DO CANDIDATO NESTA ÁREA DE ESTUDO}

A contribuição nesta área se dá com estudos que se baseiam na descrição do microbioma destes solos, sendo o destaque dado pela alteração na escala amostral. Tanto amostragens amplas, envolvendo solos de diferentes regiões e cidades, como amostragens refinadas, feitas com base no acesso aos microrganismos que incorporam exsudatos radiculares. Estes tipos de análises, geram o que é chamado aqui de análises de zoom-out e zoom-in das comunidades microbianas destes solos. Além destes enfoques, existe uma linha de trabalho, em estágio ainda inicial, que busca atribuir a diversidade microbiana dos solos, a funcionalidade de mecanismos essenciais à manutenção e funcionamento do mesmo.

Antes de detalhar estas linhas de trabalho, vale destacar o estudo que deu origem a esta linha de pesquisa, onde o candidato atuou como colaborador na descrição da comunidade microbiana associada ao solo de uma área cultivada com cana-de-açúcar:

Dini-Andreote, F; Andreote, FD; Costa, R; Taketani, RG; Elsas, JD; Araújo, WL. Bacterial soil community in a Brazilian sugarcane field. Plant and Soil, v. 336, p. 337-349, 2010. (Doc. VII1.21)

Neste estudo foi demonstrado que o cultivo de plantas de cana-de-açúcar alteradas geneticamente não resulta na alterações na composição das comunidades bacterianas do solo, sendo esta composta por grupos microbianos relacionados a diversos filos, dentre os quais destacam-se como os mais abundantes Proteobacteria, Actinobacteria, Firmicutes e Acidobacteria.

\section{III.2.1. Análises zoom-out do microbioma de solos cultivados com cana-de-açúcar}

Nesta linha de trabalho, o maior objetivo é inferir sobre a ocorrência de padrões biogeográficos (Box 2) das comunidades microbianas encontradas em solos usados para o cultivo de cana-de-açúcar. Neste intuito, um esforço amostral foi realizado entre o final do ano de 2011 e o início de 2012, onde foram coletadas um total de 412 amostras de solos, oriundas de 10 unidades produtoras de cana-de-açúcar do Estado de São Paulo (Figura III.2). 


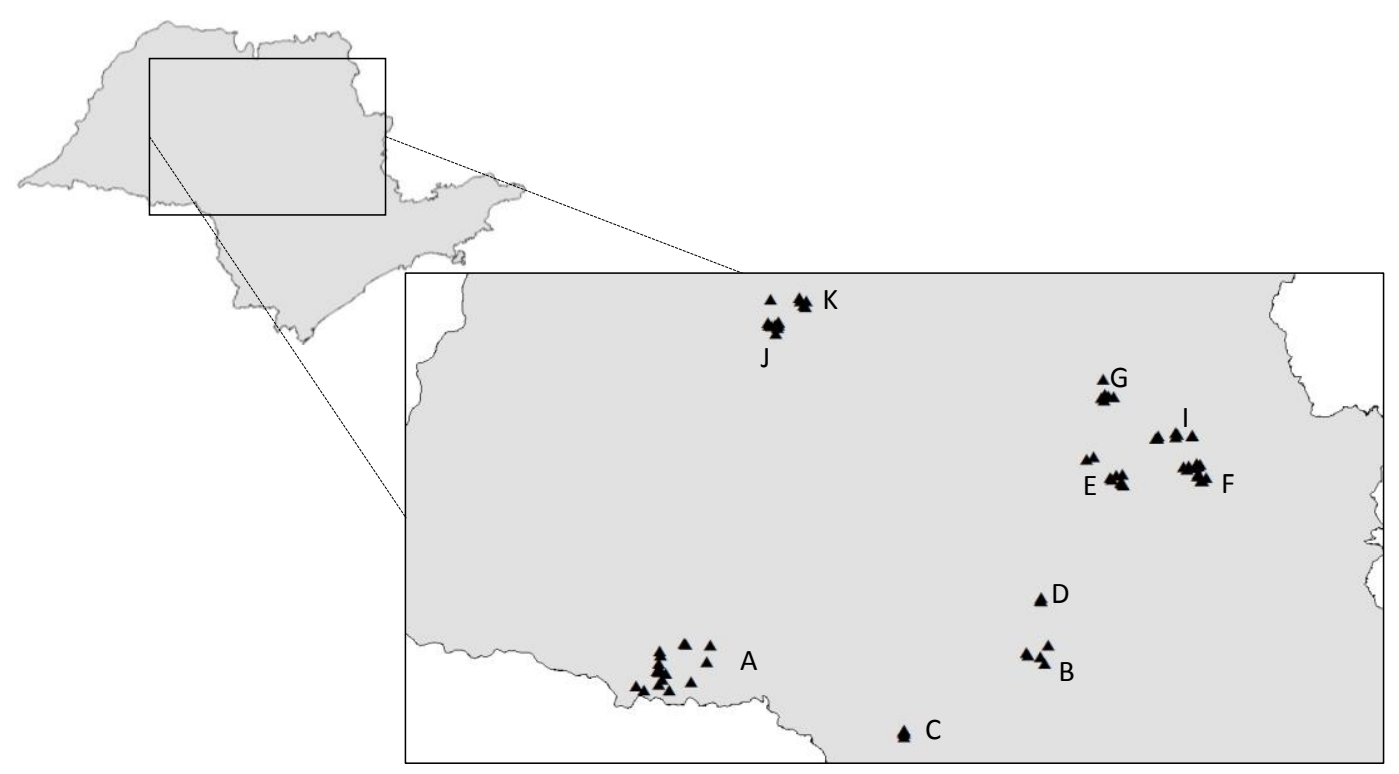

Figura III.2. Áreas amostradas no Estado de São Paulo para o acesso às comunidades microbianas do solo sob cultivo de cana-de-açúcar. Fonte: GUMIÉRE, 2013.

A partir destas amostras diversas análises foram realizadas, e algumas estão ainda sendo finalizadas. Inicialmente, a caracterização física e química destes solos revelou uma grande heterogeneidade de valores, por exemplo, com amplitudes de $\mathrm{pH}$ entre 3,7 e 7,6, quantidade de matéria orgânica entre 0,8 a 4,1\%, dentre outros (Figura III.3).

Os principais trabalhos derivados deste enfoque estão ainda na forma de dissertações e teses (uma concluída e três em andamento):

Thiago Gumiére. Biogeografia da comunidade fúngica em solos com cultivo de cana-de-açúcar.

2013. Mestrado em Solos e Nutrição de Plantas, Escola Superior de Agricultura Luiz de Queiroz - USP. Bolsista FAPESP. (Doc. XI.1.2.3)

Julia Elidia de Lima. Diversidade microbiana envolvida na ciclagem do nitrogênio em solos de cultivo de cana-de-açúcar no Estado de São Paulo. Início: 2012. Doutorado em Microbiologia Agrícola - Escola Superior de Agricultura Luiz de Queiroz - USP. Bolsista FAPESP.

Thiago Gumiere. Biogeografia microbiana em solos de cana-de-açúcar. Início: 2013. Doutorado em Solos e Nutrição de Plantas - Escola Superior de Agricultura Luiz de Queiroz - USP. Bolsista FAPESP.

Ademir Durrer Bigaton. Diversidade de bactérias e arquéias em solos com cultivo de cana-deaçúcar no Estado de São Paulo: um enfoque biogeográfico. Início: 2011. Doutorado em Microbiologia Agrícola - Escola Superior de Agricultura Luiz de Queiroz - USP. Bolsista FAPESP. 


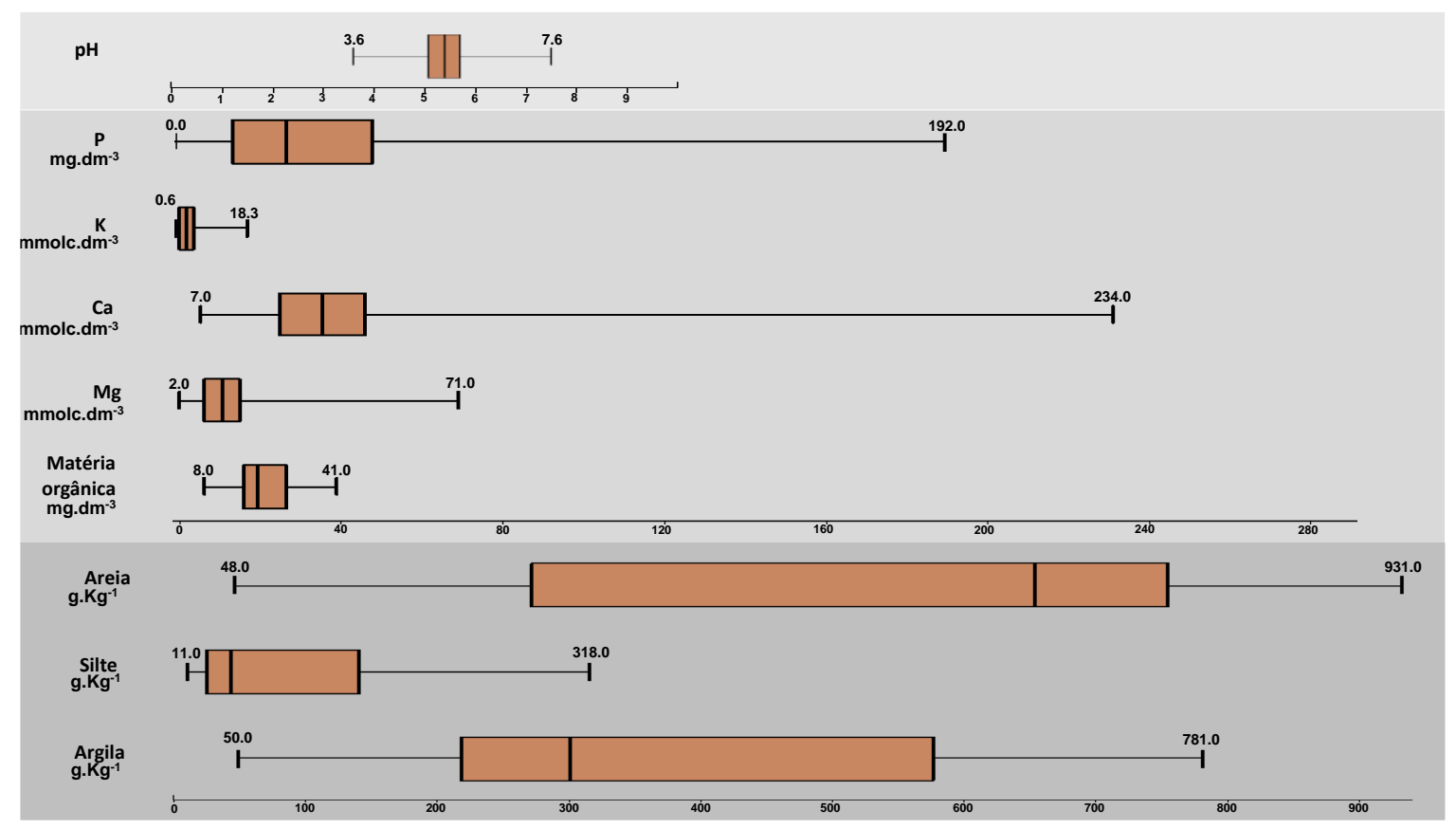

Figura III.3. Variações nas características físicas e químicas das 208 (duas repetições analisadas por talhão) amostras de solos obtidas de áreas cultivadas com canade-açúcar no Estado de São Paulo. Figura inédita.

Em relação ao estudo do microbioma, estes solos foram inicialmente explorados por meio da quantificação de bactérias, arquéias e fungos, realizada por PCR em tempo real. Os valores obtidos indicaram uma baixa variabilidade na quantidade de bactérias, com quantificações variando entre $3.10^{8}$ e $7.10^{9}$ cópias do gene $16 \mathrm{~S}$ DNAr por grama de solo (Tabela III.1). As quantificações de arquéias e fungos revelaram maiores variações na abundância de tais organismos, com arquéias variando entre $5.10^{4}$ e $8.10^{7}(16 \mathrm{~S}$ DNAr / g de solo), e fungos apresentando valores entre $10^{4}$ e $10^{7}$ cópias da região ITS por grama de solo. No entanto, considerando valores médios, pode-se concluir que a maioria numérica de células microbianas é de bactérias, seguidas de arquéias, e os menos abundantes são os fungos (Tabela III.1).

Certamente, se for acoplado a esta análise a biomassa destes grupos microbianos, será encontrada uma relação mais similar entre os grupos, uma vez que células fúngicas tem tamanho maior do que células de bactérias. Isto confere a igual importância ao acesso destes três grupos microbianos, que hospedam informações microbiológicas no sistema solo. Adicionalmente, a complementaridade metabólica de fungos, bactérias e arquéias, levam a necessidade de se obter informações dos três grupos de forma conjunta para a correta utilização dos recursos microbianos dos solos. 
Tabela III.1. Quantificação de bactérias, arquéias e fungos nas amostras de solos cultivadas com cana-de-açúcar no Estado de São Paulo. Valores apresentados em log do número de cópias do gene alvo por grama de solo, seguidos dos valores de desvio padrão (entre parênteses).

\begin{tabular}{lccc}
\hline \multicolumn{1}{c}{ Amostras } & $\begin{array}{c}\text { Bactérias } \\
(16 \mathrm{~S} \text { RNAr })\end{array}$ & $\begin{array}{c}\text { Arquéias } \\
(16 \mathrm{~S} \text { RNAr })\end{array}$ & $\begin{array}{c}\text { Fungos } \\
(\mathrm{ITS})\end{array}$ \\
\hline Área A & $9,7(0,2)$ & $5,9(0,38)$ & $5,2(0,41)$ \\
Área B & $10,1(0,14)$ & $6,4(0,40)$ & $5,7(0,44)$ \\
Área C & $9,9(0,2)$ & $6,2(0,36)$ & $5,1(0,39)$ \\
Área D & $9,8(0,1)$ & $6,1(0,33)$ & $5,3(0,30)$ \\
Área E & $9,8(0,15)$ & $6,7(0,30)$ & $5,6(0,35)$ \\
Área F & $9,8(0,13)$ & $6,6(0,30)$ & $5,4(0,45)$ \\
Área G & $10,1(0,08)$ & $6,3(0,30)$ & $5,2(0,42)$ \\
Área I & $9,4(0,18)$ & $6,5(0,6)$ & $5,0(0,64)$ \\
Área J & $9,6(0,5)$ & $7,0(0,27)$ & $5,6(0,47)$ \\
Área K & $9,7(0,26)$ & $5,3(0,33)$ & $5,5(0,83)$ \\
\hline
\end{tabular}

Associada a quantificação, foram realizadas comparações das estruturas das comunidades microbianas contidas nestes solos, por meio da análise de T-RFLP. Os perfis de picos gerados em cada uma das análises (bactérias, arquéias ${ }^{3}$ e fungos), foram convertidos em matrizes, onde cada pico foi considerado como um grupo microbiano, e a intensidade do pico foi considerada a abundância relativa dos grupos acessados (DUMBRELL et al., 2010). Estas matrizes foram inicialmente usadas na plotagem das amostras em análises de coordenadas principais (PCoA), onde foi possível verificar um agrupamento parcial de amostras da mesma área (Figura III.4). Tanto para a análise de bactérias como para a análise de fungos, algumas amostras se agruparam com as encontradas nas áreas adjacentes, mas a formação de grupos maiores, principalmente relacionados a distância entre as áreas coletadas, deram origem à primeira evidência de que a distância tem papel fundamental sobre a estruturação de comunidades microbianas nos solos estudados.

\footnotetext{
${ }^{3}$ As análises de T-RFLP de arquéias estão sendo finalizadas e serão analisadas dentro da sistemática estabelecida para fungos e bactérias.
} 
(a)

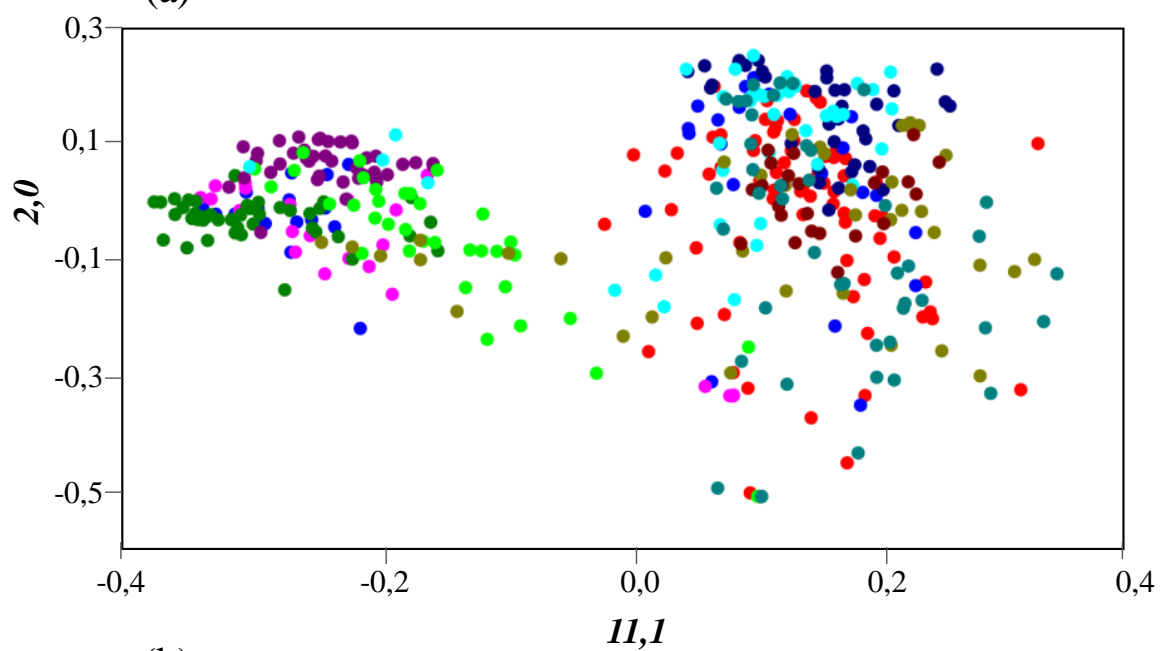

(b)

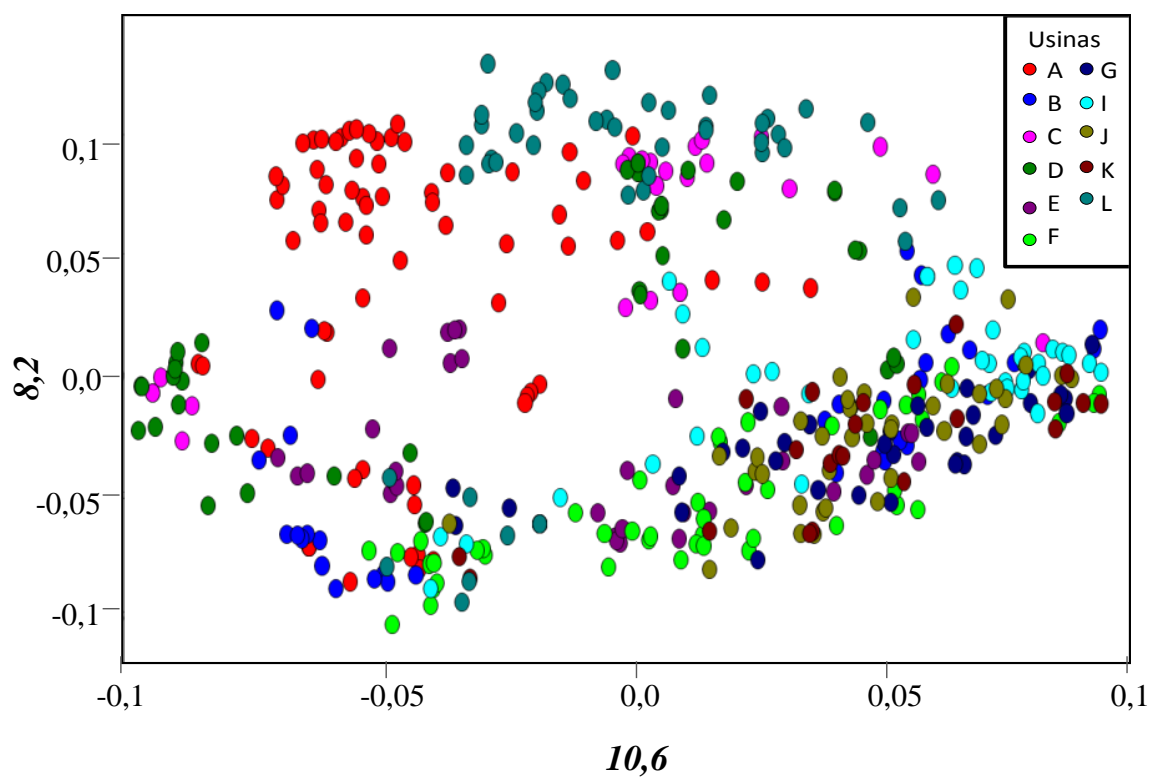

Figura III.4. Análise de coordenadas principais (PCoA) dos perfis de T-RFLP que representam as comunidades de bactérias (a) e fungos (b) encontrados nos solos cultivados com cana-de-açúcar no Estado de São Paulo. Os valores nos eixos indicam a porcentagem da variância explicada pelas coordenadas principais.

As variações encontradas na estruturação das comunidades foram então contrastadas com as variáveis ambientais, no intuito de atribuir a estas as diferenças na composição do microbioma dos solos amostrados. Estas análises foram realizadas por meio da análise de correlação de Mantel particionada (PMT), entre os dados de T-RFLP e os dados de características físicas e químicas do solo, ou de distância entre as amostras. Os resultados obtidos corroboram com a ocorrência de padrões biogeográficos na estruturação do microbiota dos solos sob cultivo de cana-de-açúcar (Figura III.5). 
A baixa explicação das variações observadas pelas alterações nas características físicas e químicas do solo (Figura III.5), juntamente com o predomínio da distância como fator primordial atuante na distinção entre as comunidades estudadas, sugerem que ocorram padrões biogeográficos em solos agrícolas, o que não foi ainda demonstrado na literatura deste tema. Esta observação se complementa ao verificar que se apenas amostras da mesma área, ou de áreas próximas forem analisadas, as variáveis físicas e químicas passam a responder por uma maior parte da variância encontrada (Figura III.5).

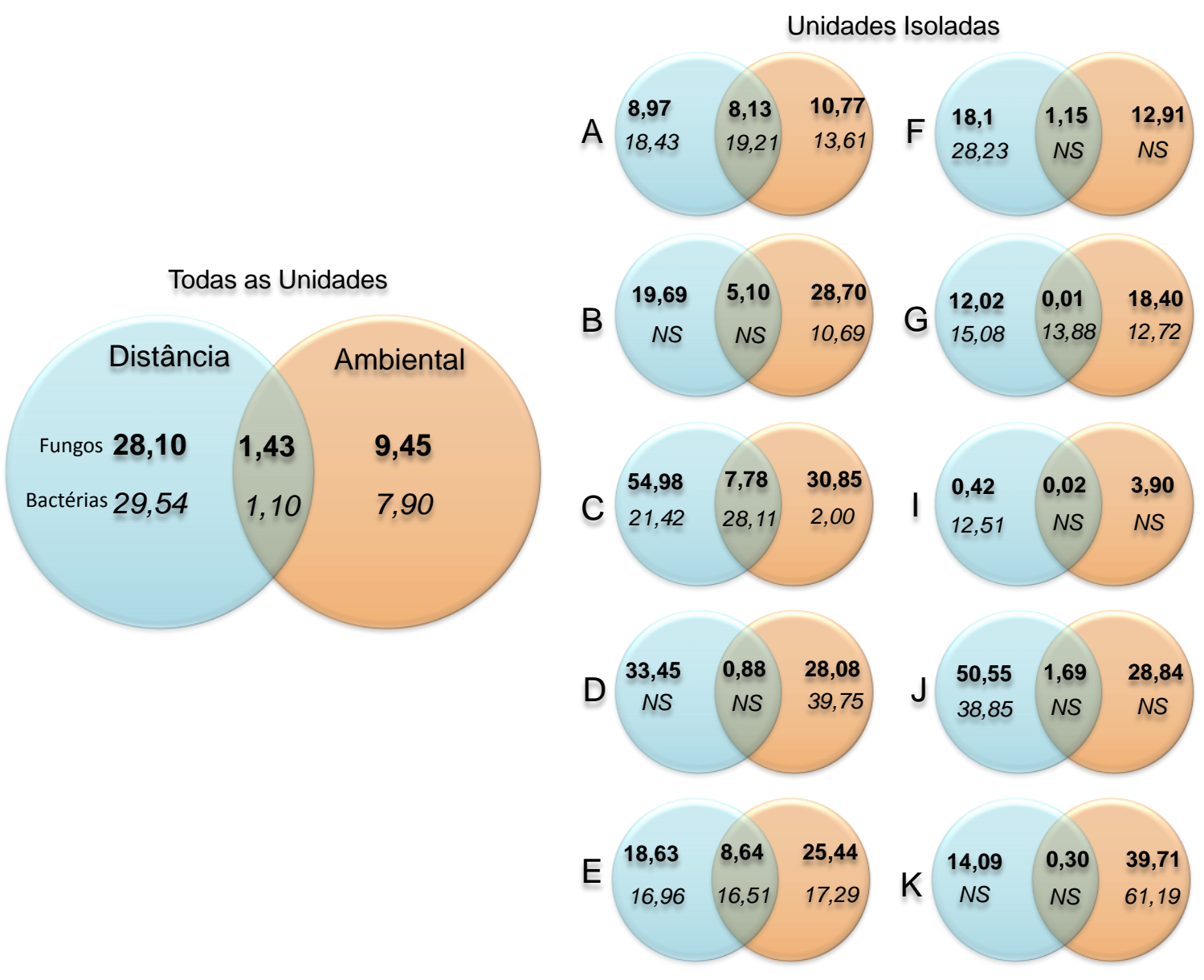

Figura III.5. Análise de partição da variância entre os componentes ambientais (física e química do solo) e a distância entre as amostras. Os resultados obtidos nas análises de fungos estão apresentados em negrito, enquanto que os resultados para as análises de bactérias aparecem em itálico. Figura inédita. 
Adicionalmente, a comunidade de bactérias presentes nestes solos foi acessada por meio da aplicação da metodologia de sequenciamento em larga escala, realizada com base na tecnologia IonTorrent (Life Technologies), onde 95 amostras foram submetidas ao sequenciamento, originando um total de 1.931.328 sequências parciais do gene ribossomal 16S RNAr (média de 20.330 sequências por amostra), agrupadas em um total de 130.448 UTOs (determinadas a 97\% de similaridade), compondo a mais robusta análise do microbioma de solos cultivados com cana-de-açúcar já realizada.

Esta análise resultou na descrição dos grupos mais abundantes em cada uma das áreas, sendo que na média dos valores obtidos, esta fração do microbioma revelou-se composta por organismos afiliados aos grupos Proteobacteria (23.1\%), Acidobacteria (21.9\%), Actinobacteria (19.9\%), Verrucomicrobia (5.1\%), Gemmatimonadetes (4.8\%), Nitrospirae (2.1\%), Chloroflexi (2.1\%), Planctomycetes (1.5\%), Firmicutes (1.3\%), Bacteroidetes (1.0\%) e outros 27 filos (1.9\%) (Figura III.6), o que parcialmente corrobora os dados de Dini-Andreote et al (2010). As pequenas alterações observadas evidenciam a importância de se realizar este tipo de inferência com base em um grande número de amostras na caracterização do microbioma de solos agrícolas. Pode-se ainda observar variações entre as áreas amostradas, sendo estas pequenas ao nível taxonômico apresentado. Atualmente, tais dados estão sendo analisados dentro de um contexto ecológico, onde o principal objetivo é determinar a fração desta comunidade responsável pela formação de padrões de biogeografia. 


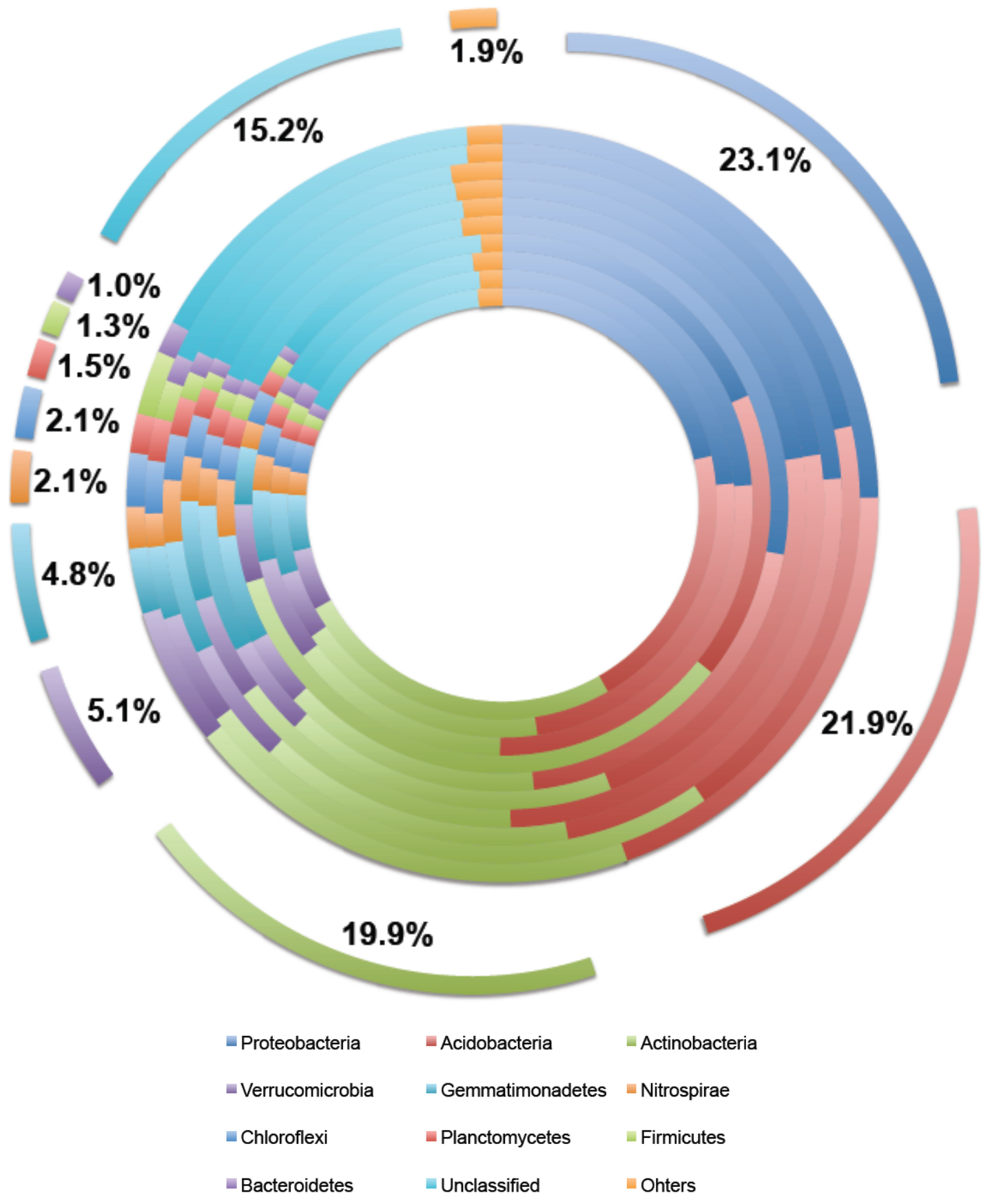

Figura III.6. Afiliação taxonômica das sequências originadas de cada uma das áreas cultivadas com cana-de-açúcar amostradas (área interna) e a distribuição média das sequências (área externa). Dentro da área interna da figura, os círculos, representam de fora para dentro, os valores obtidos para as áreas A a K, respectivamente. Figura inédita. 


\section{III.2.1.1. Aplicação de modelos ecológicos para o estudo da estruturação de comunidades microbianas em solos cultivados com cana-de-açúcar}

Um passo à frente neste tipo de estudo é composto pela aplicação de modelos de distribuição dos grupos microbianos. Os modelos de distribuição se baseiam na distribuição e na frequência dos grupos encontrados devido a processos determinísticos ou estocásticos. Os modelos determinísticos atribuem as alterações encontradas nas comunidades a variáveis bióticas e abióticas do ambiente, sendo u exemplo deste o modelo Broken-Stick. Os modelos estocásticos, como o ZSM (zero sum model) indicam que os padrões encontrados independem das variáveis ambientais, sendo estes mais relacionados a características dos organismos e dos processos de especiação que estes enfrentaram (CHAVE 2004; MCGILL et al., 2006). Alguns modelos mais robustos buscam a complementaridade entre as duas tendências, chamados de modelos gerais, que atribuem à combinação de processos determinísticos e estocásticos, a estruturação dos microbiomas estudados, sendo um exemplos destes o modelo Log-normal (MCGILL et al., 2007).

Este tipo de inferência foi realizada para o estudo das comunidades de fungos e bactérias, tendo como base a análise de T-RFLP. Os resultados obtidos são apresentados na forma de valores de Akaike's information criterion (AIC), sendo que quanto menores estes valores, mais relacionada ao modelo de distribuição se apresentam a comunidade estudada.

Os resultados indicaram que a análise geral das amostras gera um padrão de distribuição dos grupos de fungos e bactérias que se encaixam melhor em modelos estocásticos (ZSM), enquanto que as análises realizadas separadamente em cada uma das dez áreas amostradas geram tanto padrões que seguem modelos estocásticos como modelos gerais (Tabela III.2). Estes resultados confirmam, portanto, que tanto bactérias como fungos, apresentam distribuição espacial em solos agrícolas, o que faz necessário relacionar estes com características destes grupos microbianos.

Em relação aos fungos, a formação dos padrões estocásticos pode estar ligada a seu menor potencial de disseminação (em comparação com bactérias e arquéias). Somado a esta limitação do potencial de dispersão, pode-se inferir que, as áreas atualmente ocupadas pelos canaviais eram anteriormente ocupadas por florestas, que tem como característica variação espacial em suas comunidades microbianas. Assim sendo, o efeito de deriva genética, promovido pelo cultivo da cana-de-açúcar sobre comunidades fúngicas distintas, selecionou grupos fúngicos diferenciados, dando origem aos padrões de biogeografia observados no presente estudo. 
Em relação as bactérias, os maiores valores de AIC são indicativos de que mesmo com a mesma tendência, a explicação das variações encontradas pelos modelos foi mais dificultada. Isto pode estar relacionado com a maior capacidade de dispersão das bactérias, dando origem aos padrões biogeográficos. Desta forma, diferentemente dos fungos, estes organismos, por serem altamente dispersivos, colonizarem nichos abertos devido a alteração das condições ambientais naturais (constante manejo dos solos agrícolas). No intuito de comprovar esta hipótese, análises da taxa de migração de bactérias entre as amostras estão sendo conduzidas com base nas informações do sequenciamento do gene ribossomal $16 \mathrm{~S}$ RNAr destes microrganismos.

Tabela III.2. Valores AIC, oriundos da análise de modelagem das comunidades de bactérias e fungos encontradas nos solos cultivados com cana-de-açúcar. Os valores são apresentados na ordem bactérias/fungos, sendo os melhores modelos encontrados (menores valores de AIC) em cada um dos conjuntos de dados destacados em negrito.

\begin{tabular}{|c|c|c|c|}
\hline \multirow{2}{*}{$\begin{array}{l}\text { Unidades } \\
\text { Produtoras }\end{array}$} & \multicolumn{3}{|c|}{ Modelos } \\
\hline & ZSM & Broken-stick & Log-normal \\
\hline $\bar{A}$ & $1.380,90 / 101,01$ & $2.190,70 / 105,04$ & $2.273,30 / 101,26$ \\
\hline $\boldsymbol{B}$ & $1.342,80 / 105,44$ & $2.098,10 / 113,16$ & $2.277,50 / 105,86$ \\
\hline$C$ & $955,40 / 95,75$ & $1.520,90 / 99,44$ & $1.616,20 / 100,03$ \\
\hline$D$ & $1.321,60 / 105,77$ & $2.095,70 / 113,86$ & $2.195,50 / 107,94$ \\
\hline $\boldsymbol{E}$ & $1.043,70 / 103,75$ & $1.523,50 / 110,01$ & $1.629,40 / 104,54$ \\
\hline $\boldsymbol{F}$ & 736,0 / 99,04 & $1.017,20 / 121,70$ & $1.070,20 / 110,41$ \\
\hline$G$ & $\mathbf{1 . 3 5 4 , 7 0 / 9 7 , 0 7}$ & $2.143,70 / 104,01$ & $2.258,40$ / $\mathbf{9 4 , 5 4}$ \\
\hline$I$ & $1.522,60 / 79,88$ & $2.416,60 / 104,80$ & $2.654,00 / 82,70$ \\
\hline$J$ & $592,70 / 92,81$ & $823,50 / 107,47$ & 837,90 / 99,51 \\
\hline$K$ & $895,90 / 92,58$ & $1.690,70 / 105,75$ & $1.196,30 / 96,12$ \\
\hline Todas & 1.114,60 / 97,31 & $1.752,10 / 108,52$ & $1.800,90 / 100,29$ \\
\hline
\end{tabular}

Cabe ainda um comentário final neste item, onde se reforça que os padrões encontrados são relacionados a análises taxonômicas dos organismos estudados (devido as metodologias empregadas serem baseadas em fragmentos do operon ribossomal), ficando em aberta a questão sobre a ocorrência de biogeografia para grupos relacionados a funções específicas. Este tipo de análise está se iniciando no grupo liderado pelo candidato (genes 
relacionados a ciclagem de nitrogênio), mas ainda não existem dados que suportem qualquer inferência. Pode-se sugerir que uma vez que a redundância funcional é alta nos solos, organismos distintos, porém aptos a realizar funções semelhantes, possam ser selecionados, dando origem a padrões biogeográficos taxonômicos, mas não funcionais.

\section{III.2.2. Análises zoom-in da comunidade microbiana associada à cana-de-açúcar}

Este tipo de análise compõe o estudo da rizosfera de cana-de-açúcar. Nesta linha de trabalho, os projetos buscam descrever a composição das comunidades microbianas do solo responsivas a presença de raízes de cana-de-açúcar. Os principais trabalhos que compõem esta temática estão na forma de dissertações ou teses (uma finalizada e uma em andamento), além de um trabalho submetido para publicação:

Diogo Paes da Costa. Descrição da comunidade microbiana associada à rizosfera de cana-deaçúcar. 2013. Mestrado em Solos e Nutrição de Plantas, Escola Superior de Agricultura Luiz de Queiroz - USP. Bolsista FAPESP.

Danice Mazzer Luvizotto. Estudo da estrutura da comunidade bacteriana rizosférica de cana-deaçúcar por hibridização fluorescente in situ. Bolsista CNPq - Pós-doutorado Júnior (maio de 2013 a maio de 2014)

Costa, D.P.; Dias, A.C.F.; Durrer, A.; Andrade, P.A.M.; Gumiére, T.; Andreote, F.D. Composição diferencial das comunidades bacterianas na rizosfera de variedades de cana-de-açúcar. Revista Brasileira de Ciência do Solo, submetido.

Esta linha de trabalho avançou recentemente com o desenvolvimento de dois trabalhos. A primeira análise realizada neste intuito se baseou na comparação das comunidades bacterianas associadas a rizosfera de seis variedades de cana-de-açúcar (RB855156, RB85-5453, RB86-7515, PO8862, SP5541 e SP5543) cultivadas em uma mesma área (Fazendo Areão da ESALQ/USP). A comparação entre as amostras de rizosfera e do solo adjacente, por meio de PCR-DGGE, revelou que tanto quando são comparadas as comunidades de bactérias totais, ou as comunidades de Alphaproteobacteria e Betaproteobacteria, o efeito rizosférico é observado, sendo este diferencial para cada genótipo de planta analisado (Figura III.7). Isto indica que, a partir de uma matriz uniforme (solo), plantas com características genéticas distintas podem sel0ecionar organismos distintos para colonizar a região da rizosfera (COSTA, 2013). 


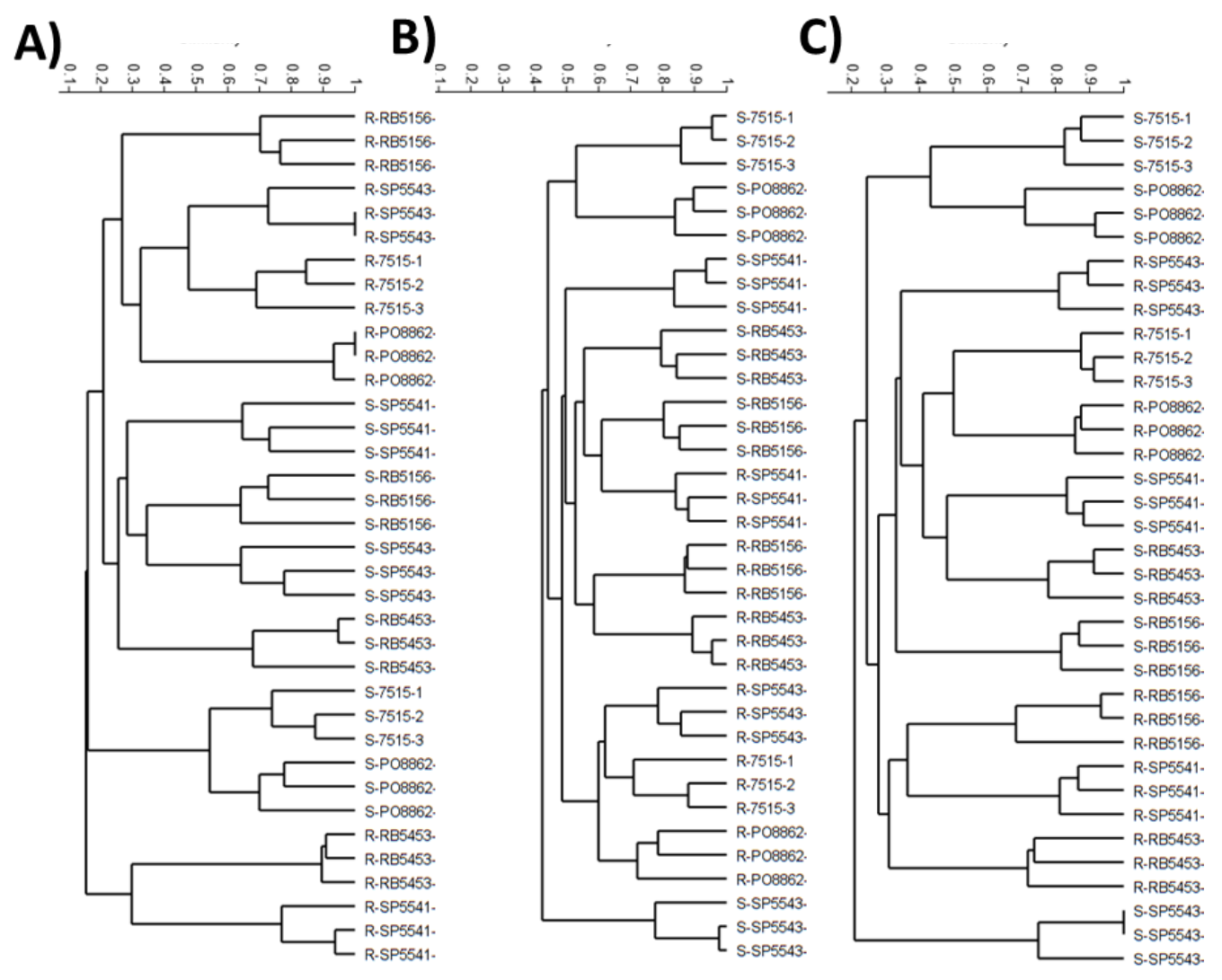

Figura III.7. Similaridade entre as comunidades bacterianas encontradas na rizosfera e no solos amostrados em seis variedades de cana-de-açúcar. A) Bactérias totais, B) Alphaproteobacteria; C) Betaproteobacteria. As amostras de solo e rizosfera são indicadas por $\mathrm{S}$ e $\mathrm{R}$, respectivamente. A similaridade foi determinada por meio da comparação dos perfis de bandas observadas nas análises de PCR-DGGE, com base no algoritmo UPGMA (Unweighted Pair-Group Method with Arithmetical Average) e no coeficiente de similaridade de Bray-Curtis. Fonte: COSTA et al., submetido.

Apesar de este efeito já ser descrito na literatura, os resultados são confirmatórios e sustentam uma nova linha de investigação, onde busca-se compreender o efeito de exsudatos radiculares comuns e específicos a diferentes genótipos de cana-de-açúcar, sobre o desenvolvimento de grupos bacterianos específicos encontrados na rizosfera desta planta. Um trabalho em desenvolvimento visa determinar quais são estes compostos, e a potencialidade dos mesmos alterarem a multiplicação e/ou o metabolismo dos organismos colonizadores da rizosfera de cana-de-açúcar.

Um segundo enfoque buscou confirmar a responsividade de grupos microbianos a exsudação radicular, e nomear os organismos mais rapidamente responsíveis a presença das raízes de cana-de-açúcar. Neste estudo foi empregada a metodologia de SIP (stable isotope probing), onde $\mathrm{o} \mathrm{CO}_{2}$ fornecido às plantas foi marcado com o isótopo estável ${ }^{13} \mathrm{C}$. Esta 
análise foi realizada cultivando-se as plantas sob duas concentrações distintas de $\mathrm{CO}_{2}(350$ e 700ppm). Após incubação das plantas, e a consequente marcação do DNA dos microrganismos que assimilaram os exsudatos radiculares das plantas, foi realizada a extração de DNA de amostras da rizosfera, e a separação do DNA marcado foi promovida por meio de ultra-centrifugação. As frações leve e pesada do DNA foram então utilizadas para as inferências de diferenciação das comunidades (COSTA, 2013).

Uma análise inicial, baseada nos perfis de T-RFLP das comunidades de bactérias e fungos encontrados nas frações de DNA, revelou inicialmente a ocorrência de grupos de bactérias e fungos diferenciados na rizosfera de plantas cultivadas sob diferentes concentrações de $\mathrm{CO}_{2}$ (Figura III.8). Adicionalmente, a separação entre as comunidades encontradas no DNA total daquela representada no DNA marcado foi observada, sendo que as frações marcadas mostraram-se mais similares entre os tratamentos com diferentes concentrações do $\mathrm{CO}_{2}$ do que as comunidades representadas pelo DNA total (Figura III.8). Estas observações validam o experimento, e dão base para a descrição refinada dos organismos rizosféricos que utilizam os exsudatos radiculares das plantas submetidos as diferentes condições de cultivo.

(a)

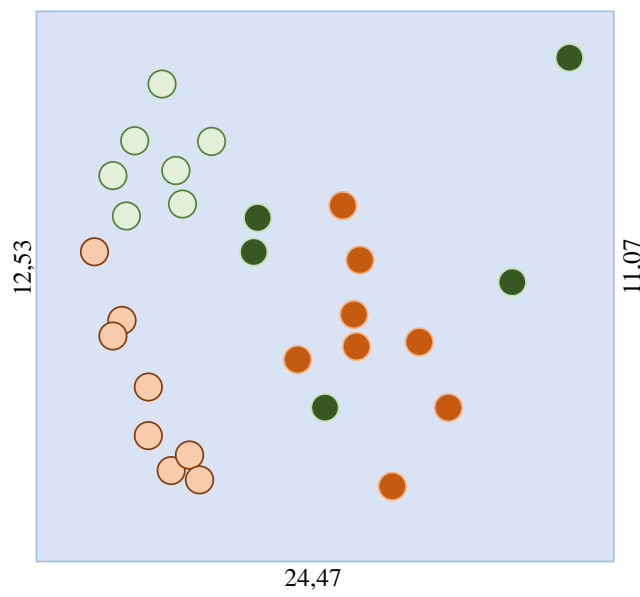

(b)

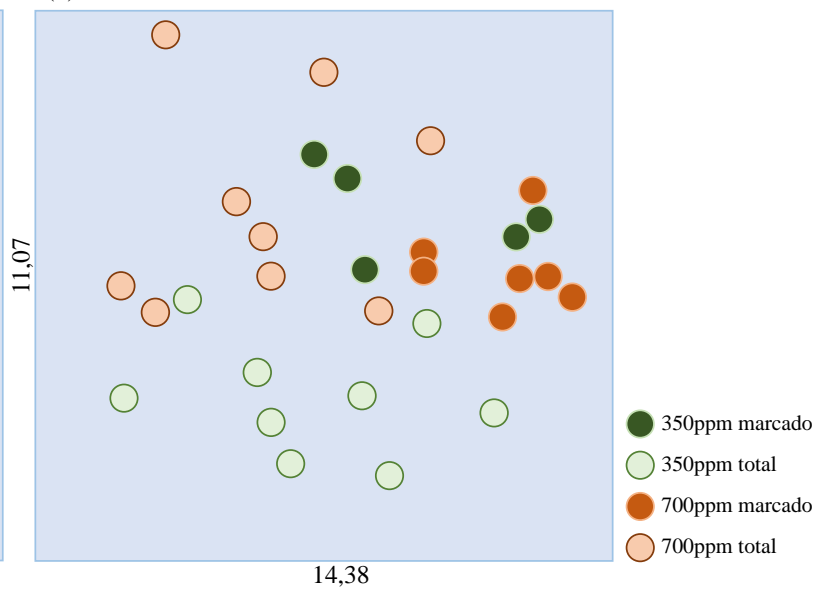

Figura III.8. Análise de PCoA, com base nos perfis de T-RFLP das comunidades de bactérias (a) e fungos (b) encontradas na rizosfera de plantas de cana-de-açúcar cultivadas sob condições de 350 e $700 \mathrm{ppm}$ de $\mathrm{CO}_{2}$. Apresenta-se também a comparação entre os perfis obtidos a partir do DNA total da rizosfera e do DNA marcado com o ${ }^{13} \mathrm{CO}_{2}$. A variação no número de repetições se dá devido ao insucesso de obter DNA marcado de todas as repetições biológicas avaliadas. Os valores nos eixos indicam a porcentagem da variância explicada pelas coordenadas principais. Fonte: COSTA (2013). 
Além da análise de fingerprinting (T-RFLP), as frações leves e pesada do DNA oriundo das amostras de rizosfera foram submetidos ao sequenciamento parcial da região 16S DNAr via metodologia de IonTorrent. Esta análise revelou a afiliação taxonômica dos principais grupos microbianos envolvidos na captação dos compostos carbônicos liberados pelas raízes de cana-de-açúcar. Estes dados estão ainda em análise, mas é pode-se adiantar uma das observações; considerando o DNA total, o grupo taxonômico predominante é o filo Firmicutes, no entanto, se a análise for realizada no DNA marcado, a maior parte das sequências obtidas se afiliam a organismos do filo Proteobacteria.

A complementação desta linha de pesquisa está sendo realizada num projeto que busca determinar, por meio da aplicação da metodologia de FISH (fluorescent in situ hybridization), a distribuição espacial de grupos bacterianos descritos acima na rizosfera de cana-de-açúcar.

\section{III.2.3. A biodiversidade como promotora do funcionamento do sistema solo}

Além do estudo do microbioma de solos e da rizosfera de cana-de-açúcar, há uma linha de trabalho que visa atribuir à biodiversidade e às interações microbianas, o funcionamento do sistema solo, destacando funções dependentes da diversidade microbiana neste ambiente. Alguns trabalhos relatam a interação entre a diversidade microbiana do solo e o desenvolvimento de grupos microbianos e a presença de processos específicos. Sabe-se, por exemplo, que a invasão do sistema solo por organismos exógenos é dependente da diversidade microbiana do solo receptor, sendo esta inversamente proporcional às chances de sobrevivência de um organismo exógeno, como um patógeno humano (VITOUSEK et al., 2006; VAN ELSAS et al., 2012; JOUSSET et al., 2011). Neste sentido, o trabalho que está sendo realizado busca descrever a importância da diversidade microbiana do solo no desenvolvimento da interação entre os fungos micorrízicos arbusculares e as plantas. Esta inferência foi feita inicialmente por Nogueira e Cardoso (2002), que observaram a menor eficiência de colonização das raízes por estes fungos quando inseridos em solos esterilizados. 
Até o momento, uma dissertação de mestrado foi finalizada e uma tese de doutorado está em andamento com foco nesta temática:

Pedro Avelino Maia de Andrade. A composição da comunidade bacteriana do solo como fator determinante na micorrização de cana-de-açúcar por Glomus clarum. 2013. Mestrado em Solos e Nutrição de Plantas, Escola Superior de Agricultura Luiz de Queiroz - USP. Bolsista CNPq.

Dorotéia Alves Ferreria. Interação de fungos micorrízicos com a diversidade bacteriana em solos de cana-de-açúcar. Início: 2012. Doutorado em Solos e Nutrição de Plantas - Escola Superior de Agricultura Luiz de Queiroz - USP. Bolsista FAPESP.

Os ensaios são realizados utilizando diluições da comunidade microbiana natural do solo, buscando desta forma diminuir progressivamente a diversidade microbiana, num processo conhecido como 'diluição para a extinção'. Num ensaio realizado com cana-deaçúcar e o fungo micorrízico arbuscular (FMA) Glomus clarum (recentemente renomeado como Rhizophagus clarus), os resultados foram bastante promissores, observando-se uma tendência a menores valores de colonização das plantas, associados a maior produção de esporos dos FMA, em solos contendo menor diversidade microbiana (Figura III.9).

Nos estudos que serviram como molde para este tipo de análise, as interações exploradas eram apenas entre componentes do microbioma dos solos (VAN ELSAS et al., 2012; JOUSSET et al., 2011). Já em nosso sistema de estudo, ocorre uma dificuldade adicional devido a presença da microbiota da planta, que pode ter papel fundamental nos tratamentos com maior diluição da comunidade natural. A estratégia que está sendo usada para sobrepor tal dificuldade combina o uso de mudas micropropagadas, com menores quantidades de microrganismos em relação a mudas obtidas de colmos, e a utilização de diluições menores da diversidade inicial, o que revela a resposta da diversidade microbiana do solo, minimizando assim o efeito da microbiota da própria planta. Ainda, ensaios baseados na germinação de esporos de FMA estão sendo conduzidos, onde estes são submetidos a condições de solo artificial suplementado com diferentes valores de diversidade microbiana, buscando assim observar o efeito sobre o desenvolvimento do FMA em um ambiente livre do efeito da planta. 
(a)

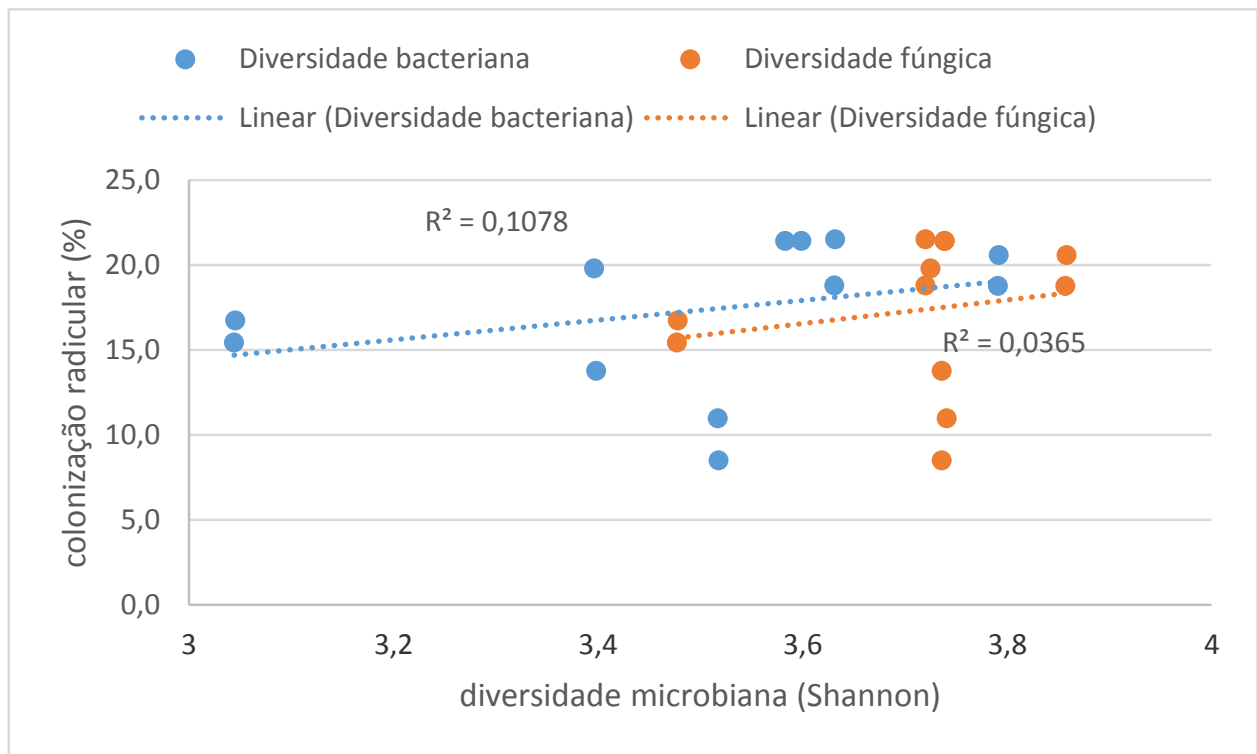

(b)

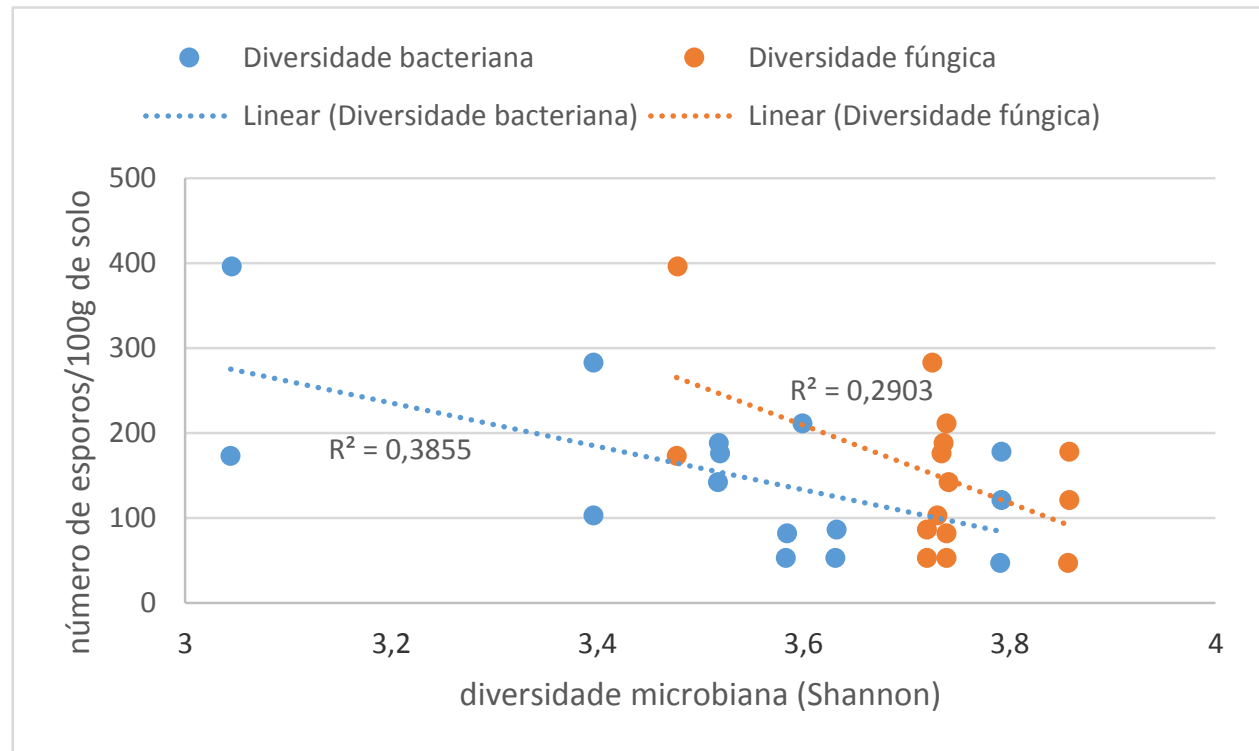

Figura III.9. Evolução da colonização radicular (a) e do número de esporos (b) de Rhizopus clarus em interação com plantas de cana-de-açúcar cultivadas em solos com diferentes valores de diversidade microbiana. Fonte: ANDRADE (2013).

No entanto, como os resultados de colonização de FMA são sempre atrelados a quantificações com altos coeficientes de variação, esta análise está sendo repetida com maiores números de repetições, e também envolvendo outros FMA, como Scutellospora heterogama (Dentiscutata heterogama) e Gigaspora rosea.

Pode-se derivar destes resultados, mesmo que ainda parciais, uma importante observação, onde a degradação dos solos, e sua consecutiva degeneração da diversidade microbiana, podem ter impactos enormes não apenas em características físicas e químicas 
dos solos, mas também no funcionamento do microbioma deste ambiente. Isto leva o contexto de degradação biológica do solo para as discussões sobre uso da terra, manejo e conservação dos solos.

Outras funções presentes no sistema solo deverão ser exploradas no futuro, sendo uma delas já definida, onde a capacidade do solo em biodegradar agroquímicos será avaliada frente a diferentes valores de diversidade microbiana.

\section{III.3. Perspectivas futuras PARA O ESTUdo do MiCROBioma EM SOlOS CUlTIVAdOS COM CANA-DE-AÇÚCAR}

A agricultura mundial se desenvolveu devido a capacidade do homem de selecionar os indivíduos mais sadios e produtivos, e retirar a partir destes a semente para os cultivos posteriores, juntamente com a capacidade de melhorar as condições do solo para fornecer os nutrientes necessários para o desenvolvimento vegetal. Ao longo de toda sua história evolutiva, as práticas agrícolas selecionaram, mesmo de forma inconsciente, a microbiota presente nos solos, que hospedam características essenciais ao desenvolvimento das plantas. No entanto, a onipresença destes organismos jamais foi explorada de forma racional, sendo esta capacidade possivelmente a base da próxima revolução nas práticas agrícolas e no desenvolvimento de tecnologias mais sustentáveis de produção agrícola. Neste sentido, os trabalhos apresentados nesta sessão se desenvolvem no intuito de ampliar as bases do conhecimento, sobre as quais estratégias para o uso da microbiota residente nos solos agrícolas deverão ser desenvolvidas.

Alguns dos projetos apresentados estão em fase de finalização, e a publicação dos mesmos em revistas de ampla visibilidade se faz necessária. Dentre estes, destaca-se o trabalho de biogeografia, onde a finalização das análises de arquéias, e das sequências de genes ribossomais de bactérias deverão suprir as informações necessárias para gerar a partir dos resultados algo bastante inovador. O mesmo tipo de análise, porém com base em genes relacionados as transformações de nitrogênio (já em andamento) adicionarão um contexto de funcionamento do sistema a este tipo de inferência. Um outro ponto que merece destaque, trata da biogeografia temporal das comunidades microbianas, sendo este tema abordado em uma tese de Doutorado, onde serão determinadas as alterações das comunidades microbianas em solos de cana-de-açúcar ao longo dos cinco anos de cultivo da planta sob diferentes tratamentos. 
De maneira complementar a estas análises, um projeto recém aprovado pelo candidato (FAPESP-NWO), traz como tema de trabalho o efeito da manutenção da palhada da cana-de-açúcar sobre os solos. Esta proposta visa entender o efeito da adição deste material sobre o microbioma destes solos, bem como indicar os melhores manejos, do ponto de vista microbiano, para um desenvolvimento vegetal mais eficiente.

Do ponto de vista das análises apresentadas nesta sessão como zoom-in, as perspectivas são da complementação dos resultados já gerados. Uma vez que foi comprovada a seleção na rizosfera de planta de cana-de-açúcar, o próximo objetivo é a caracterização dos compostos liberados pelas raízes desta planta, e o efeito dos mesmos sobre organismos responsivos ao ambiente rizosférico. Para responder a esta última questão, podem ser usadas análises que visam a descrição das comunidades microbianas na rizosfera, ou então o estudo de organismos na forma de isolados. A segunda possibilidade se mostra bastante atrativa neste contexto, principalmente devido a possibilidade de se cultivar representantes dos principais grupos microbianos que se mostraram responsivos a rizosfera de cana-de-açúcar (experimento de SIP). Dessa forma, apresenta-se o cenário perfeito para acessar o efeito de compostos específicos, liberados pela planta, sobre o metabolismo, ou mesmo sobre a estruturação genética, de organismos rizosféricos. Este é um dos temas de um trabalho de tese que está se iniciando sob orientação do candidato. Pode-se derivar deste tipo de análise, a ocorrência de pan-genomas diferenciais para determinados grupos microbianos, quando acessados no solo adjacente (bulk soil) ou na rizosfera.

De forma integrada as demais frentes de trabalho, variando tanto em macro como em micro-escala dentro do cenário agrícola, existe o estudo de serviços ambientais dependentes da diversidade microbiana dos solos. Como comentado anteriormente, os resultados obtidos para o processo de colonização das plantas por FMA, evidenciam que muitos processos que ocorrem nos solos dependem da diversidade microbiana, que deve estar presente e ativa neste ambiente. No intuito de verificar esta dependência, outras características dos solos, atribuídas ao seu componente microbiano, deverão ser avaliadas, como por exemplo, a degradabilidade de agroquímicos.

Os solos agrícolas compõem um sistema de origem antrópica, porém com grande parte de seu funcionamento regido por sistemas naturais, o que torna esta quimera ambiental importante alvo de estudo. O desenvolvimento de trabalhos detalhados sobre os mesmos podem tanto revelar seu lado mais primitivo, onde os processos são muito similares aos encontrados em solos de biomas naturais, bem como podem levar a descrição de processos unicamente encontrados neste ambiente. 


\section{CONSIDERAÇÕES FINAIS}

"If I could do it all over again, and relive my vision in the twenty-first century, I would be a microbial ecologist"

Edward O. Wilson

A exuberância da biodiversidade brasileira se sustenta sobre uma outra biodiversidade, que atua na ciclagem dos elementos químicos, e sustentam o desenvolvimento vegetal (e por conseguinte animal) nos diferentes biomas brasileiros. Conhecer os organismos responsáveis por estes processos é por si só um desafio, e fazer uso deste recurso natural onipresente soa ainda utópico num cenário de alta competitividade do cenário agrícola mundial. Neste sentido, a linha de trabalho desenvolvida pelo candidato visa contribuir no conhecimento, e consequentemente na utilização racional dos organismos componentes do microbioma presentes nos solos brasileiros.

Os resultados apresentados neste documento são de grande importância, sendo a maioria deles inéditos nas áreas de estudo em que se inserem. A partir dos solos estudados foram descritos os organismos componentes de seus respectivos microbiomas, bem como a estruturação funcional dos mesmos, seja esta com base no estudo de genes relacionados a metabolismos específicos, ou em análises mais completas, como o sequenciamento de material genético obtido diretamente do solo. No entanto, pode-se considerar que estes resultados têm um caráter ainda bastante exploratório, tendo como principais objetivos a descrição de grupos microbianos presentes nos diferentes solo, ou a existência de padrões de colonização dos mesmos nas áreas exploradas. Uma visão mais tecnológica dos processos pode ser vislumbrada na comparação entre os componentes taxonômicos e funcionais que ocorrem em solos sob distintos estados de conservação, ou ainda sob diferentes condições de contaminação ambiental. Uma possibilidade neste sentido, talvez ainda utópica, seria a indicação de manejos agrícolas que favoreçam o incremento de grupos ou funções benéficas microbianas, relacionadas ao incremento no desenvolvimento vegetal.

No entanto, apesar de todos os avanços apresentados no estudo de comunidades microbianas, ainda podem ser enumeradas limitações e desafios nesta área de pesquisa. Um destes pontos é a relação entre a taxonomia e a funcionalidade microbiana, o que ganha grande importância em ambientes como o solo, que apresentam comunidades microbianas com grande redundância funcional, ao mesmo tempo em que alguns de seus organismos são providos de grande plasticidade genômica. Talvez o que explique este tipo de processo, e 
componha o maior dos desafios no avanço dos estudos de ecologia microbiana, seja um fator intrínseco às características dos organismos componentes destas comunidades. Tanto a organização genômica, como a regência metabólica destes organismos são por vezes vistas pelos pesquisadores como similares aquelas encontradas em animais e plantas, mas possivelmente do ponto de vista evolutivo, estas sejam estruturas bastante distintas dos mesmos. De forma mais clara e direta, esta dificuldade se dá na compreensão da ocorrência e do comportamento de organismos quando em níveis mais detalhados de taxonomia, como gêneros e 'espécies', nem sempre são constantes como encontrados em outros grupos de organismos. Sabe-se por exemplo, que organismos alocados dentro de uma mesma espécie podem apresentar características metabólicas muito distintas, de acordo com o ambiente de onde foi obtido. Esta observação justifica o uso da palavra 'espécies' entre aspas ao longo deste documento, de forma a deixar clara a visão do candidato sobre este conceito aplicado a ecologia microbiana. Dessa forma, é de extrema importância considerar a fluidez genética que existe nos componentes de comunidades microbianas complexas, o que certamente levará os estudos de ecologia microbiana a outro patamar nos próximos anos.

Aplicando este conceito na área de atuação do candidato, e integrando o mesmo nos resultados apresentados neste documento, uma enorme possibilidade de estudos surge, sendo estes altamente desafiadores, porém igualmente promissores na geração de resultados inovadores sobre o conhecimento da estruturação de comunidades e genomas microbianos presentes no solo. No entanto, o desenvolvimento desta frente depende da capacidade de acessarmos de maneira eficiente a informação genética contida nas células microbianas. Neste ponto, mesmo com o avanço nas metodologias de sequenciamento, pode ser de extrema importância retornarmos ao ponto de partida da revolução na ecologia microbiana, e utilizarmos novamente organismos cultivados como modelos para o estudo de evolução e estruturação genômica.

Assim sendo, este momento do desenvolvimento científico no estudo de comunidades microbianas ambientais, dentre as quais as presentes nos solos, é de extrema riqueza, onde as metodologias se apresentam em pleno desenvolvimento, gerando um cenário de 'tudo é possivel', o que dá base a grande evolução no desenvolvimento científico, mas também engrandece a capacidade do pesquisador, sobrepujando a capacidade do mesmo de ser criativo e fazer aos seus conjuntos de dados os devidos questionamentos. Vale ainda um paralelo, onde tanto em situações de limitações tecnológicas, como na abundância das mesmas, a ciência dá seus maiores passos por meio de idéias inovadoras, e visões holísticas processuais, as quais são ainda, apenas passíveis de serem realizadas no cérebro humano. 


\section{REFERÊNCIAS BIBLIOGRÁFICAS}

ABREU, U.G.P.; LOPES, P.S.; BAPTISTA, A.J.M.S.; TORRES, R.A.; SANTOS, H.N. Avaliação da introdução de tecnologias no sistema de produção de gado de corte no Pantanal. Análise de eficiência. Revista Brasileira de Zootecnia, 35(3): 1242-1250, 2006.

ALONGI, D.M. Bacterial productivity and microbial biomass in tropical mangrove sediments. Microbial Ecology 15:59-79, 1988.

ALONGI, D.M.; BOTO, K.G.; TIRENDI, F. Effect of exported mangrove litter on bacterial productivity and dissolved organic carbon fluxes in adjacent tropical nearshore sediments. Marine Ecology Progress Series, 56: 133-144, 1989.

ALVIM, M.I.S.A.; VALLE, S.M.L.R.; LIMA, J.E.; SILVA, O.M. Análise da competitividade da produção de soja nos sistemas de plantio direto e plantio convencional na região do cerrado brasileiro. Revista de Economia e Sociologia Rural, 42(2): 223-242, 2004.

AMANN, R.I.; LUDWING, W.; SCHLEIFER, K.H. Plylogenetic identification and in situ detection of individual microbial cells without cultivation. Microbiology Reviews, 59: 143-169, 1995.

ANDERSON, I.C.; CAMPBELL, C.D.; PROSSER, J.I. Diversity of fungi in organic soils under a moorland-Scots pine (Pinus Sylvestris L.) gradient. Environmental Microbiology, 5: 11211132, 2003.

ANDRADE, P.A.M. A composição da comunidade bacteriana do solo como fator determinante na micorrização de cana-de-açúcar por Glomus clarum. 2013. 73f. Mestrado (Solos e Nutrição de Plantas) - Escola Superior de Agricultura “Luiz de Queiroz", Universidade de São Paulo, Piracicaba, 2013.

ANDREOTE, F.D.; AZEVEDO, J.L.; ARAÚJO, W.L. Assessing the diversity of bacterial communities associated with plants. Brazilian Journal of Microbiology, 40: 417-432, 2009.

ANDREOTE, F.D.; JIMENEZ, D.J.; CHAVES, D.; DIAS, A.C.F.; LUVIZOTTO, D.M. et al. The microbiome of Brazilian mangrove sediments as revealed by metagenomics. PLoS One, 7: $238600,2012$.

ARAÚJO, J.E. Detecção e análise de sequências de Planctomycetes em metagenomas de manguezais. 2014. 73f. Mestrado (Microbiolgia Agrícola) - Escola Superior de Agricultura “Luiz de Queiroz”, Universidade de São Paulo, Piracicaba, 2014.

BALDANI, J.I.; CARUSO, L.V.; BALDANI, V.L.; GOI, S.R.; DOBEREINER, J. Recent advances in BNF with non-legume plants. Soil Biology \& Biochemistry, 29: 911-922, 1997.

BARTZ, M.L.C.; PASINI, A.; BROWN, G.G. Earthworms as soil quality indicators in Brazilian notillage systems. Applied Soil Ecology, 69: 39- 48, 2013. 
BERNHARD, A.E.; TUCKER, J.; GIBLIN, A.E.; STAHL, D.A. 2007. Functionally distinct communities of ammonia-oxidizing bacteria along an estuarine salinity gradient. Environmental Microbiology, 9: 1439-1447, 2007.

BOON, E.; MEEHAN, C.J.; WHIDDEN, C.; WONG, D.H.J.; LANGILLE, M.G.I. et al. Interactions in the microbiome: communities of organisms and communities of genes. FEMS Microbiology Reviews, 38: 90-118, 2014.

BRADY, N.C.; WEIL, R.R. Elementos da Natureza e Propriedades dos Solos, $3^{\text {a }}$ Edição. Ed Artmed, 716 p., 2013.

BUOL, S.W.; HOLE, F.D.; MCCRACKEN, R.J.; SOUTHARD, R.J. Soil genesis and classification. John Wiley \& Sons. $4^{\text {th }}$ Edition. 1997.

CAMARA, R.; CORREIA, M.E.F.; VILLELA, D.M. Effects of eucalyptus plantations on soil arthropod communities in a Brazilian Atlantic forest conservation unit. Bioscience Journal, 28(3): 445-455, 2012

CARVALHAIS, L.C.; DENNIS, P.G.; TYSON, G.W.; SCHENK, P.M. Application of metatranscriptomics to soil environments. Journal of Microbiological Methods, 91: 246-251, 2012.

CHAGNON, P.L.; BRADLEY, R.L.; MAHERALI, H.; KLIRONOMOS，J.N. A trait-based framework to understand life history of mycorrhizal fungi. Trends in Plant Science, 18: 484491, 2013.

CHAVE, J.; ALONSO, D.; ETIENNE, R.S. Theoretical biology: comparing models of species abundance. Nature, 441(1): 1-2. 2006.

CLEARY, D.F.R.; SMALLA, K.; MENDONÇA-HAGLER, L.C.S.; GOMES, N.C.M. Assessment of variation in bacterial composition among microhabitats in a mangrove environment using DGGE fingerprints and barcoded pyrosequencing. PLoS One, 7: e29380, 2012.

CONAB. Companhia Nacional de Abastecimento (Imprensa/Notícias e Levantamento de Safras, 2010/11). www.conab.gov.br. Acessado em 15/02/2011.

COSTA, D.P. Descrição da comunidade microbiana associada à rizosfera de cana-de-açúcar. 2013. 103f. Mestrado (Solos e Nutrição de Plantas) - Escola Superior de Agricultura "Luiz de Queiroz”, Universidade de São Paulo, Piracicaba, 2013.

COSTA, F.M.; SCHIAVO, J.A.; BRASIL, M.S.; LEITE, J.; XAVIER, G.R. et al. Phenotypic and molecular fingerprinting of fast growing rhizobia of field-grown pigeonpea from the eastern edge of the Brazilian Pantanal. Genetics and Molecular Research, 13(1): 469-482, 2014. 
CURY, J.C. Diversidade de Bacteria e Archea em solos de mangue e marisma. 2006. 147f. Tese (Doutorado em Solos e Nutrição de Plantas) - Escola Superior de Agricultura "Luiz de Queiroz”, Universidade de São Paulo, Piracicaba, 2006.

DAMON, C.; LEHEMBRE, F.; OGER-DESFEUX, C.; LUIS, P.; RANGER, J. et al. Metatranscriptomics Reveals the Diversity of Genes Expressed by Eukaryotes in Forest Soils. PLoS One 7(1): e28967, 2012.

DIAS, A.C.F.; ANDREOTE, F.D.; RIGONATO, J.; FIORE, M.F.; MELO, I.S. et al. The bacterial diversity in a Brazilian non-disturbed mangrove sediment. Antonie Van Leeuwenhoek, 98: 541$551,2010$.

DIAS, A.C.F.; DINI-ANDREOTE, F.; TAKETANI, R.G.; TSAI, S.M.; AZEVEDO, J.L. et al. Archaeal communities in sediments of three contrasting mangroves. Journal of Soils and Sediments, 11: 1466-1476, 2011.

DIAS, A.C.F.; PEREIRA E SILVA, M.C.; COTTA, S.R.; DINI-ANDREOTE, F.; SOARES JR., F.L. et al. Abundance and genetic diversity of nifH gene sequences in anthropogencally affected Brazilian mangrove sediments. Applied and Environmental Microbiology, 78: 7960-7967, 2012 .

DIAS, A.C.F. Diversidade de arquéias e bactérias envolvidas na ciclagem do nitrogênio em sedimentos de manguezais. 2012. 98f. Tese (Doutorado em Biologia na Agricultura e no Ambiente) - Centro de Energia Nuclear na Agricultura, Universidae de São Paulo, Piracicaba, 2012.

DINI-ANDREOTE, F.; ANDREOTE, F.D.; ARAÚJO, W.L.; TREVORS, J.T.; VAN ELSAS, J.D. Bacterial Genomes: habitat specificity and uncharted organisms. Microbial Ecology, 64: 1-7, 2012.

DINI-ANDREOTE, F.; ANDREOTE, F.D.; COSTA, R.; TAKETANI, R.G.; VAN ELSAS, J.D. et al. Bacterial soil community in a Brazilian sugarcane field. Plant and Soil, 336: 337-349, 2010.

DJIKENG, A.; NELSON, B.J.; NELSON, K.E. Implications of the human microbiome research for the developing world. In: NELSON, K.E. Metagenomics of the Human Body. New York: Springer: 317-336, 2011.

DOMINGUEZ-BELLO, M.G.; COSTELLO, E.K.; CONTRERAS, M.; MAGRIS, M.; HIDALGOD, G. et al. Delivery mode shapes the acquisition and structure of the initial microbiota across multiple body habitats in newborns. Proceedings of the National Academy of Science of the USA, 107: 11971-11975, 2010.

DOLAN, J.R. Microbial biogeography? Journal of Biogeography, 33(2): 199-200, 2006. 
DUKE, N.C.; MEYNECKE, J.O.; DITTMANN, S. et al. A world without mangroves? Science, 317: 41-42, 2007.

DUMBRELL, A.J.; NELSON, M.; HELGASON, T.; DYTHAM, C.; FITTER, A.H. Relative roles of niche and neutral processes in structuring a soil microbial community. The ISME Journal, 4: $337-345,2010$.

EICHORST, S.A.; KUSKE, C.R.; SCHMIDT, T.M. Influence of plant polymers on the distribution and cultivations of bactéria in the phylum Acidobacteria. Applied and Environmental Microbiology, 77: 586-596, 2011.

FASANELLA, C.C.; DIAS, A.C.F.; RIGONATO, J.; FIORE, M.F.; SOARES JR., F.L. et al. The selection exerted by oil contamination on mangrove fungal communities. Water, Air and Soil Pollution, 223: 4233-4243, 2012.

FERREIRA, T.O.; OTERO, X.L.; SOUZA, V.S.; VIDAL-TORRADO, P.; MACÍAS, F. et al. Spatial patterns of soil attributes and components in a mangrove system in Southeast Brazil (São Paulo). Journal of Soils and Sediments, 10: 995-1006, 2010.

FIERER, N.; BRADFORD, M.A.; JACKSON, R.B. Toward an ecological classification of soil bacteria. Ecology, 88: 1354-1364, 2007.

FIERER, N.; JACKSON, R.B. The diversity and biogeography of soil bacterial communities. Proceedings of the National Academy of Science of United States of America, 103(3): 626$631,2006$.

FIERER, N.; LADAU, J.; CLEMENTE, J.C.; LEFF, J.W.; OWENS, S.M. et al. Reconstructing the microbial diversity and function of pre-agricultural tallgrass prairie soils in the United States. Science, 342(6158): 621-624, 2013.

FRACETTO, G.G.M.; AZEVEDO, L.C.B.; FRACETTO, F.J.C.; ANDREOTE, F.D.; LAMBAIS, M.R. et al. Impact of amazon land use on the community of soil fungi. Scientia Agrícola, 70: 5967, 2013.

FRANCO, H.C.J.; VITTI, A.C.; FARONI, C.E.; CANTARELLA, H.; TRIVELIN, P.C.O. Estoque de nutrientes em resíduos culturais incorporados ao solo na reforma do canavial. STAB-Açúcar, Álcool e Subprodutos, 25: 32-36, 2007.

FRIAZ-LOPEZ, J.; SHI, Y.; TYSON, G.M.; COLEMAN, M.L.; SCHUSTER, S.C. et al. Microbial community gene expression in ocean surface waters. Proceedings of the National Academy of Science of United States of America, 105: 3805-3810, 2008. 
GALDOS, M.V.; CERRI, C.C.; LAL, R.; BERNOUX, M.; FEIGL, B. et al. Net greenhouse gas fluxes in Brazilian ethanol production systems. Global Change Biology Bioenergy, 2: 37-44, 2010.

GEETS, J.; BORREMANS, B.; DIELS, L.; SPRINGAEL, D.; VANGRONSVELD, J. et al. dsrB gene-based DGGE for community and diversity surveys of sulfate-reducing bacteria. Journal of Microbiological Methods, 66: 194-205, 2006.

GILBERT, J.A.; FIELD, D.; HUANG, Y.; EDWARDS, R.; LI, W. et al. Detection of large numbers of novel sequencer in the metetranscriptomes of complex marine microbial communities. PloS One, 3: 3042, 2008.

GILLER, P.S. The diversity of soil communities, the 'poor man's tropical rainforest'. Biodiversity and Conservation, 5: 135-168, 1996.

GIRI, C.; OCHIENG, E.; TIESZEN, L.L.; ZHU, Z.; SINGH, A. et al. Status and distribution of mangrove forests of the world using earth observation satellite data. Global Ecology and Biogeography, 20(1): 154-159, 2011.

GIULIETTI, A.M.; HARLEY, R.; QUEIROZ, L.P.; RAPINI, A. To selt the science. In: QUEIROZ, L.P.; RAPIINI, A.; GIULIETTI, A.M. (Ed.) Towards greater knowledge of the Brazilian Semi-arid Biodiversity. Brasília: Ministério da Ciência e Tecnologia, 11-15, 2006.

GOMES, N.C.M.; BORGES, L.R.; PARANHOS, R.; PINTO, F.N.; MENDONÇA-HAGLER, L.C.S. et al. Exploring the diversity of bacterial communities in sediments of urban mangrove forests. FEMS Microbiology Ecology, 66: 96-109, 2008.

GORLACH-LIRA, K.; COUTINHO, H.D.M. Population dynamics and extracellular enzymes activity of mesophilic and thermophilic bacteria isolated from semi-arid soil of northeastern Brazil. Brazilian Journal of Microbiology, 38: 135-141, 2007.

GUMIERE, T. Biogeografia da comunidade fúngica em solos com cultivo de cana-de-açúcar. 2012. 75f. Mestrado (Solos e Nutrição de Plantas) - Escola Superior de Agricultura "Luiz de Queiroz”, Universidade de São Paulo, Piracicaba, 2012.

GRAHAM, E.B.; WIEDER, W.R.; LEFF, J.W.; WEINTRAUB, S.R.; TOWNSEND, A.R. et al. Do we need to understand microbial communities to predict ecosystem function? A comparasion of statistical models of nitrogen cycle processes. Soil Biology Biochemistry, 68: 279-282. 2014.

HANDELSMAN, J.; RONDON, M.R.; BRADY, S.F.; CLARDY, J.; GOODMAN, R.M. Molecular biological access to the chemistry of unknown soil microbes: a new frontier for natural products. Chemical Biology, 5: 245-24, 1998. 
HANSON, R.S.; HANSON, T.E. Methanotrophic bacteria. Microbiological Reviews, 60:439-471, 1996.

HE, S.; WURTZEL, O.; SINGH, K.; FROULA, J.L.; YILMAZ, S. et al. Validation of two ribosomal RNA removal methods for microbial metatranscriptomics. Nature Methods, 7(10): 807-12, 2010.

HENCKEL, T.; ROSLEV, P.; CONRAD, R. Effects of $\mathrm{O}_{2}$ and $\mathrm{CH}_{4}$ on presence and activity of the indigenous methanotrophic community in rice field soil. Environmental Microbiology, 2: 666$679,2000$.

HENRY, S.; BRU, D.; STRES, B.; HALLET, S.; PHILIPPOT, L. Quantitative detection of the nosZ gene, encoding nitrous oxide reductase, and comparison of the abundances of 16S rRNA, narG, nirK, and nosZ genes in soils. Applied and Environmental Microbiology, 72: 5181-5189, 2006.

HEUER, H.; KRSEK, M.; BAKER, P.; SMALLA, K.; WELLINGTON, E.M.H. Analysis of actinomycete communities by specific amplification of genes encoding 16S rRNA and gelelectrophoretic separation in denaturing gradients. Applied and Environmental Microbiology, 63: 3233-3241, 1997.

HOLGUIN, G.; VAZQUEZ, P.; BASHAN, Y. The role of sediment microorganisms in the productivity, conservation, and rehabilitation of mangrove ecosystems: an overview. Biology and Fertility of Soils, 33: 265-278, 2001.

HOLGUIN, G.; ZAMORANO, P.G.; BASHAN, L.E.D.; MENDOZA, R.; AMADOR, E. et al. Mangrove health in an arid environment encroached by urban development - a case study. Science of Total Environment, 363: 260-274, 2006.

JANSSEN, P.H. Identifying the dominant soil bacterial taxa in libraries of 16S rRNA and 16S rRNA genes. Applied and Environmental Microbiology, 72: 1719-1728, 2006.

JANSSON, J.K.; PROSSER, J.I. Microbiology: The life beneath our feet. Nature, 494: 40-41, 2013

JESUS, E.C.; MARSH, T.L.; TIEDJE, J.M.; MOREIRA, F.M.S. Changes in land use alter the structure of bacterial communities in Western Amazon soils. The ISME Journal, 3: 1004-1011, 2009.

JOUSSET, A.; SCHULZ, W.; SCHEU, S.; EISENHAUER, N. Intraspecific genotypic richness and relatedness predict the invasibility of microbial communities. The ISME Journal, 5(7): 1108$1114,2011$.

JUNK, W.J.; CUNHA, C.N.; WANTZEN, K.M.; PETERMANN, P.; STRÜSSMANN, C. et al. Biodiversity and its conservation in the Pantanal of Mato Grosso, Brazilian Aquatic Science, 68: 278-309, 2006. 
KAHINDI, J.H.P.; WOOMER, P.; GEORGE, T.; MOREIRA, F.M.S.; KARANJA, N.K. et al. Agricultural intensification, soil biodiversity and ecosystem function in the tropics: the role of nitrogen fixing bacteria. Applied Soil Ecology, 6: 55-76, 1997.

KAMPF, N.; CURI, N. Argilominerais em Solos Brasileiros. In: CURI, N.; MARQUES, J.J.G.S.M.; GUILHERME, L.R.G.; LIMA, J.M.; LOPES, A.S.; ALVAREZ V.V.H. Tópicos em Ciência do Solo III. Viçosa: Sociedade Brasileira de Ciência do Solo, 1-54, 2000.

KATHIRESAN, K.; BINGHAM, B.L. Biology of mangroves and mangrove ecosystems. Advances in Marine Biology, 40: 81-251, 2001.

KAVAMURA, V.N.; SANTOS, S.N.; SILVA, J.L.; PARMA, M.M.; AVILA, L.A. et al. Screening of Brazilian cacti rhizobacteria for plant growth promotion under drought. Microbiological Research, 168: 183-191, 2013.

KAVAMURA, V.N.; TAKETANI, R.G.; LANÇONI, M.D.; ANDREOTE, F.D.; MENDES, R. et al. Water regime influences bulk soil and rhizosphere of Cereus jamacaru bacterial communities in the Brazilian caatinga biome. PLoS One, 8: e73606, 2013.

KER, J.C. Latossolos do Brasil: uma revisão. Genomos 5: 17-40, 1997.

LAMBAIS, M.R.; CROWLEY. D.; CURY, J.C.; BULL, J.C.; RODRIGUES, R.R. Bacterial diversity in tree canopies of the Atlantic forest. Science, 312:1917-1917, 2006.

LEDERBERG, J.; MCCRAY, A.T. 'Ome Sweet 'Omics-a genealogical treasury of words. Scientist, 15: 8, 2001.

LEHEMBRE, F.; DOILlON, D.; DAVID, E.; PERROTTO, S.; BAUDE, J. et al. Soil metatranscriptomics for mining eukaryotic heavy metal resistance genes. Environmental Microbiology, 15(10): 2829-2840, 2013.

LEPSCH, I.F. 19 Lições de Pedologia. Oficina do texto, 456p. 2011.

LEY, R.E.; TURNBAUGH, P.J.; KLEIN, S.; GORDON, J.I. Microbial ecology: human gut microbes associated with obesity. Nature, 444: 1022-1023, 2006.

LIANG, J.B.; CHEN, Y.Q.; LAN, C.Y.; TAM, N.F.Y.; ZAN, Q.J. et al. Recovery of novel bacterial diversity from mangrove sediment. Marine Biology, 150: 739-747, 2007.

LIMA, J.E. Diversidade de bactérias e arquéias em solos da mata atlântica. 2012. Dissertação (Mestrado em Microbiologia Agrícola) - Escola Superior de Agricultura "Luiz de Queiroz", Universidade de São Paulo, Piracicaba, 2012.

LUPATINI, M.; SULEIMAN, A.K.A.; JACQUES, R.J.S.; ANTONIOLLI, Z.I.; KURAMAE, E.E. et al. Soil-borne bacterial structure and diversity does not reflect community activity in Pampa biome. PLoS One, 8(10): e76465, 2013. 
LUVIZOTTO, D.M.; MARCON, J.; ANDREOTE, F.D.; DINI-ANDREOTE, F.; NEVES, A.A.C. et al. Genetic diversity and plant-growth related features of Burkholderia spp. from sugarcane roots. World Journal of Microbiology and Biotechnology, 26: 1829-1836, 2010.

MAGNANI, G.S.; DIDONET, C.M.; CRUZ, L.M.; PICHETH, C.F.; PEDROSA, F.O. et al. Diversity of endophytic bacteria in Brazilian sugarcane. Genetics and Molecular Research, 9: 250-258, 2010.

MARTINY, J.B.H.; BOHANNAN, B.J.M.; BROWN, J.H.; COLWELL, R.K.; FUHRMAN, J. et al . Microbial biogeography: putting microorganisms on the map. Nature Reviews in Microbiology, 4(2): 102-12, 2006.

MCGILL, B.J.; ETIENNE, R.S.; GRAY, J.S.; ALONSO, D.; ANDERSON, M.J. et al. Species abundance distributions: moving beyond single prediction theories to integration within an ecological framework. Ecology Letters, 10:995-1015, 2007.

MCGILL, B.J.; MAURER, B.A.; WEISER, M.D. Empirical evaluation of neutral theory. Ecology, 87: 1411-23, 2006.

MENDES, L.W.; KURAMAE, E.E.; NAVARRETE, A.A.; VAN VEEN, J.A.; TSAI, S.M. Taxonomical and functional microbial community selection in soybean rhizosphere. The ISME Journal, in press.

MENDES, R.; KRUIJT, M.; DE BRUIJN, I.; DEKKERS, E.; VAN DER VOORT, M. et al. Deciphering the rhizosphere microbiome for disease-suppressive bacteria. Science, 332: 10971100, 2011.

MENDES, R.; PIZZIRANI-KLEINER, A.A.; ARAÚJO, W.L.; RAAIJMAKERS, J.M. Diversity of cultivated endophytic bacteria from sugarcane: genetic and biochemical characterization of Burkholderia cepacia complex isolates. Applied and Environmental Microbiology, 73: 7259_ 7267, 2007.

MICHEREFF, S.J.; BARROS, R. Proteção de plantas na agricultura sustentável. 2001, 368 p. Recife. UFRPE, Imprensa Universitária, 2001.

Ministério do Meio Ambiente - MMA Brazilian biodiversity - Assessment and identification of areas and priority actions for conservation, sustainable use and benefit sharing of biodiversity across brazilian biomes MMA/SBF, Brasília, 2002. Disponível em http://www.mma.gov.br/estruturas/chm/_arquivos/Prioritary_Area_Book.pdf

MIRANSARI, M. Soil microbes and the availability of soil nutrients. Acta Physiologiae Plantarum, 35: 3075-3084, 2013. 
MOREIRA, F.M.S.; SIQUEIRA, J.O. Microbiologia e Bioquímica do Solo. 1. ed. Lavras: Editora UFLA, 626p., 2002.

MOREIRA, M.; BARETTA, D.; TSAI, S.M.; GOMES DA COSTA, S.M.; CARDOSO, E.J.B.N. Biodiversity and distribution of arbuscular mycorrhizal fungi in araucaria forest. Scientia Agricola, 64: 393-399, 2007.

NACKE, H.; FISCHER, C.; THÜRNER, A.; MEINICKE, P.; DANIEL, R. Land use type significantly affects microbial gene transcription in soil. Microbial Ecology, in press.

NICHOLSON, J.K.; HOLMES, E.; KINROSS, J.; BURCELIN, R.; GIBSON, G. et al. Host-gut microbiota metabolic interactions. Science, 336: 1262-1267, 2012.

NOGUEIRA, M.A.; CARDOSO, E.J.B.N. Interações microbianas na disponibilidade e absorção de manganês por soja. Pesquisa Agropecuária Brasileira, 37(11): 1605-1612, 2002.

NOVAIS, R.F.; ALVAREZ, V.; BARROS, N.F.; FONTES, R.L.F.; CANTARUTTI, R.B.; NEVES, J.C.L. Fertilidade do Solo. Viçosa: Sociedade Brasileira de Ciência do Solo, 1017p. 2007.

OFEK, M.; VORONOV-GOLDMAN, M.; HADAR, Y.; MINZ, D. Host signature effect on plant root-associated microbiomes revealed through analyses of resident $v s$ active communities. Environmental Microbiology, in press.

OLFF, H.; DE LEEUW, J.; BAKKER, J.P.; PLATERINK, R.J.; VAN WIJNEN, H.J. Vegetation succession and herbivory in a salt marsh: changes induced by sea level rise and silt deposition along an elevational gradient. Journal of Ecology, 85: 799-814, 1997.

OTERO, X.L.; FERREIRA, T.O.; HUERTA-DÍAZ, M.A.; PARTITI, C.S.M.; SOUZA, V. et al. Geochemistry of iron and manganese in soils and sediments of a mangrove system, Island of Pai Matos (Cananeia - SP, Brazil). Geoderma, 148(3/4): 318-335, 2009.

PHILIPPOT, L.; RAAIJMAKERS, J.M.; LEMANCEAU, P.; VAN DER PUTTEN, W.H. Going back to the roots: the microbial ecology of the rhizosphere. Nature Reviews Microbiology, 11, 789-799, 2013.

PORETSKY, R.S.; BANO, N.; BUCHAN, A.; LECLEIER, G.; KLEIKEMPER, J. et al. Analysis of microbial gene transcripts in environmental samples. Applied and Environmental Microbiology, 71: 4121-4126, 2005.

PORETSKY, R.S.; SUN, S.; MOU, X.; MORAN, M.A. Transporter genes expressed by coastal bacterioplankton in response to dissolved organic carbon. Environmental Microbiology, 12: 616-627, 2010. 
PYLRO, V.S.; ROESCH, L.F.W.; ORTEGA, J.M.; AMARAL, A.M.; TÓTOLA, M.R. et al. Brazilian Microbiome Project: revealing the unexplored microbial diversity challenges and prospects. Microbial Ecology, 67: 237-241, 2014.

RACHID, C.T.C.C.; SANTOS, A.L.; PICCOLO, M.C.; BALIEIRO, F.C.; COUTINHO, H.L.C. et $a l$. Effect of sugarcane burning or green harvest methods on the Brazilian cerrado soil bacterial community structure. Plos One, 8: e59342, 2013.

RANJARD, L.; POLY, F.; NAZARET, S. Monitoring complex bacterial communities using cultureindependent molecular techniques: application to soil environment. Research in Microbiology, 151: 167-177, 2000.

RAYMOND, J.; SIEFERT, J.L.; STAPLES, C.R.; BLANKENSHIP R.E. The natural history of nitrogen fixation. Molecular Biology and Evolution, 21: 541-554, 2004.

RELMAN, D.A. New technologies, human-microbe interactions, and the search for previously unrecognized pathogens. Journal of Infectious Diseases, 186: S254-S258, 2002.

RODRIGUES, J.L.M.; PELliZARI, V.H., MUELlER, R.; BAEK, K.; JESUS, E.D. et al. Conversion of the Amazon rainforest to agriculture results in biotic homogenization of soil bacterial communities. Proceedings of the National Academy of Science of United States of America, 110: 988-993, 2013.

ROESCH, L.F.W.; DAROUB, S.H.; FULTHORPE, R.R.; TRIPLETT, E.W.; CAMARGO, F.A.O. et al. Pyrosequencing enumerates and contrasts soil microbial diversity. The ISME Journal, 1: 283-290, 2007.

ROESCH, L.F.W.; VIEIRA, F.C.B.; PEREIRA, V.A.; SCHUNEMANN, A.L.; TEIXEIRA, I.F. et al. The Brazilian Pampa: A Fragile Biome. Diversity, 1: 182-198, 2009.

ROMAGNOLI, E.M. Diversidade de arquéias amônio-oxidantes em solos de mata atlântica do estado de São Paulo. 2012. Dissertação (Mestrado em Microbiologia Agrícola) - Escola Superior de Agricultura “Luiz de Queiroz”, Universidade de São Paulo, Piracicaba, 2012.

ROSSETO, R. A cana-de-açúcar e a questão ambiental. In: DINARDO-MIRANDA, L.L.; VASCONCELOS, A.C.M.; LANDELL, M.G.A. Cana-de-açúcar. Riberão Preto: Instituto Agronômico, 1: 869-882, 2008.

SAMPAIO, E.; RODAL, M.D.J. Fitofisionomias da caatinga. In: Biodiversitas Avaliação e identificação de Ações prioritárias para a conservação, utilização sustentável e repartição de benefícios da biodiversidade do bioma Caatinga. Petrolina, 2000. Disponível em HTTP://biodiversitas.org/caatinga/relatorios/fitofisionomias.pdf. 
SANGWAN, N.; LATA, P.; DWIVEDI, V.; SINGH, A.; NIHARIKA, N. et al. Comparative metagenomic analysis of soil microbial communities across three hexachlorocyclohexane contamination levels. PLoS One, 7(9): e46219, 2012.

SANTOS, E.C.; ARMAS, E.D.; CROWLEY, D.; LAMBAIS, M.R. Artificial neural network modeling of microbial community structures in the Atlantic Forest of Brazil. Soil Biology and Biochemistry, 69: 101-109, 2014.

SANTOS, H.F.; CARMO, F.L.; PAES, J.E.; ROSADO, A.S.; PEIXOTO, R.S. Bioremediation of mangroves impacted by petroleum. Water, Air and Soil Pollution, 216: 329-350, $2011 \mathrm{~b}$.

SANTOS, H.F.; CURY, J.; CARMO, F.L.; SANTOS, A.L.; TIEDJE, J. et al. Mangrove bacterial diversity and the impact of oil contamination revealed by pyrosequencing: bacterial proxies for oil pollution. Plos One, 6: e16943, 2011a.

SANTOS, S.N.; KAVAMURA, V.N.; CASTANHA, R.F.; ANDREOTE, F.D.; CARVALHO, J.E. et al. Antitumoral, antioxidant and antimicrobial molecules from Combretum rupicola. International Journal of Pharma and Bio Sciences, 4: 422-428, 2013.

SANTOS, S.N.; KAVAMURA, V.N.; SILVA, J.L.; MELO, I.S.; ANDREOTE, F.D. Plant growth promoter rhizobacteria in plants inhabiting harsh tropical environments and its role in agricultural improvements. In: DINESH K MAHESHWARI. (Org.). Plant Growth and Health Promoting Bacteria. 1ed. Berlim: Springer-Verlag, 1: 251-272, 2010.

SCHAEFFER-NOVELLI, Y.; CINTRON-MOLERO, G.; ADAIME, R.R.; CAMARGO, T.M. Variability of mangrove ecosystems along the Brazilian coast. Estuaries, 13, 204-218, 1990.

SIIKAMÄKI, J.; ,SANCHIRICO, J.N.; JARDINE, S.L. Global economic potential for reducing carbon dioxide emissions from mangrove loss. Proceedings of the National Academy of Science of United States of America, 109(36): 14369-14374, 2012.

SILVA, J.S.V.; ABDON, M.M. Delimitação do pantanal brasileiro e suas sub-regiões. Pesquisa agropecuária brasileira, 33: 1703-1711, 1998.

SIMON, C.; WIEZER, A.; STRITTMATTE, A.W.; DANIEL, R. Phylogenetic diversity and metabolic potential revelead in a glacier ice metagenome. Applied and Environmental Microbiology, 75: 7519-7526, 2009.

SITTERS, J.; MAECHLER, M-J.; EDWARDS, P.J.; SUTER, W.; VENTERINK, H.O. Interactions between $\mathrm{C}: \mathrm{N}: \mathrm{P}$ stoichiometry and soil macrofauna control dung decomposition of savanna herbivores. Functional Ecology, in press. 
SOARES JR., F.L. Isolamento e caracterização de bactérias celulolíticas de ambientes extremos. 2011. 58f. Mestrado (Biotecnologia) - Universidade de Mogi das Cruzes, Mogi das Cruzes, 2011.

SOUZA, D.M.G.; LOBATO, E.; REIN, T.A. Uso de gesso agrícola nos solos de cerrado - Planaltina, DF: Embrapa Cerrados, 2005.

STALEY, J.T.; KONOPKA, A. Measurement of in situ activities of non-photosynthetic microorganisms in aquatic and terrestrial habitats. Annual Review of Microbiology, 39: 321$346,1985$.

STUART, R.M.; ROMÃO, A.S.; PIZZIRANI-KLEINER, A.A.; AZEVEDO, J.L.; ARAÚJO, W.L. Culturable endophytic filamentous fungi from leaves of transgenic imidazolinone-tolerant sugarcane and its non-transgenic isolines. Archives of Microbiology, 192: 307-313, 2010.

The Human Microbiome Project Consortium. Structure, function and diversity of the healthy human microbiome. Nature, 486: 207-214, 2012.

THOMAS, W.W.; CARVAlHO, A.M.V.; AMORIM, A.M.A.; GARRISON, J. et al. Plant endemism in two forests in southern Bahia, Brazil. Biodiversity and Conservation, 7: 311-322, 1998.

TOBAR-TOSSE, F.; RODRÍGUEZ, A.C.; VELEZ, P.E.; ZAMBRANO, M.M.; MORENO, P.A. Exploration of noncoding sequences in metagenomes. PLoS One, 8(3): e59488, 2013.

TRINGE, S.G.; VON MERING, C.; KOBAYASHI, A.; SALAMOV, A.A.; CHEN, K. et al. Comparative metagenomics of microbial communities. Science, 308(5721): 554-557, 2005.

TURNBAUGH, P.J.; LEY, R.E.; HAMADY, M.; FRASER-LIGGETT, C.M.; KNIGHT, R. et al. The human microbiome project. Nature, 449: 804-810, 2007.

TURNBAUGH, P.J.; LEY, R.E.; MAHOWALD, M.A.; MAGRINI, V.; MARDIS, E.R. et al. An obesity-associated gut microbiome with increased capacity for energy harvest. Nature, 444: 1027-103, 2006.

TYSON, G.W.; CHAPMAN, J.; HUGENHOLTZ, P.; ALLEN, E.E.; RAM, R.J. et al. Community structure and metabolism through reconstruction of microbial genomes from the environment. Nature, 428(6978): 37-43, 2004.

URICH, T.; LANZEN, A.; QI, J.; HUSON, D.H.; SCHLEPER, C. et al. Simultaneous assessment of soil microbial community structure and function through analysis of the meta-transcriptome. PLoS One, 3(6): e2527, 2008. 
VAN ELSAS, J.D.; CHIURAZZI, M.; MALLON, C.A.; ELHOTTOVA, D.; KRIŠTUFEK, V. et al. Microbial diversity determines the invasion of soil by a bacterial pathogen. Proceedings of the National Academy of Science of United States of America, 109(4): 1159-1164.

VAN SLUYS, M.A.; MONTEIRO-VITORELLO, C.B.; CAMARGO, L.E.A.; MENCK, C.F.M.; RASERA, A.C. et al. Comparative genomic analysis of plant-associated bacteria. Annual Review of Phytopathology, 40: 169-189, 2002.

VARON-LOPEZ, M. Descrição da microbiota relacionada às transformações do enxofre em sedimentos de manguezais. 2013. 108f. Doutorado (Microbiologia Agrícola) - Escola Superior de Agricultura “Luiz de Queiroz”, Universidade de São Paulo, Piracicaba, 2013.

VARON-LOPEZ, M.; DIAS, A.C.F.; FASANELlA, C.C.; DURRER, A.; MELO, I.S. et al. Sulphur-oxidizing and sulphate-reducing communities in Brazilian mangrove sediments. Environmental Microbiology, 16: 845-855, 2014.

VIDAL-TORRADO, P.; LEPSH, I.; CASTRO, S. S. Conceitos e aplicações das relações pedologiageomorfologia em regiões tropicais úmidas. Tópicos em Ciência do Solo, 4: 145-192, 2005.

VITOUSEK, P.M.; DANTONIO, C.M.; LOOPE, L.L.; WESTBROOKS, R. Biological invasions as global environmental change. American Scientist, 84:468-478, 1996.

VITTI, A.C.; TRIVELIN, P.C.O.; GAVA, G.J.C.; FRANCO, H.C.J.; BOLOGNA, I.R. et al. Produtividade da cana-de-açúcar relacionada à localização de adubos nitrogenados aplicados sobre os resíduos culturais em canavial sem queima. Revista Brasileira de Ciência do Solo, 31 : 491-498, 2007.

VITTI, G.C. Acidez e calagem do solo. Revista Laranja, 5:77-102, 1984.

VOGEL, T.M.; SIMONET, P.; JANSSON, J.K.; HIRSCH, P.R.; TIEDJE, J.M. et al. TerraGenome: a consortium for the sequencing of a soil metagenome. Nature, 7: 252, 2009.

WELLER, D.M.; RAAIJMAKERS, J.M.; GARDENER, B.B.M.; THOMASHOW, L.S. Microbial populations responsible for specific soil suppressiveness to plant pathogens. Annual Reviews of Phytopathology, 40: 309-348, 2002.

YAN, B.; HONG, K.; YU, Z.N. Archaeal communities in mangrove soil characterized by $16 \mathrm{~S}$ rRNA gene clones. Journal of Microbiology, 44: 566-571, 2006. 


\section{ANEXOS \\ Anexo I - Resumos dos trabalhos que embasam este documentos}

Abaixo são apresentados os resumos dos trabalhos referenciados como de autoria do candidato que dão base ao documento sistematizado apresentado acima. A ordem de apresentação dos mesmos é a mesma em que estes aparecem no texto.

\section{REVISÃo BIBLIOGRÁFICA}

Andreote, FD; Azevedo, JL; Araújo, WL. Assessing the diversity of bacterial communities associated with plants. Brazilian Journal of Microbiology, v. 40, p. 417-432, 2009. (Doc. VII-1.16)

Resumo: As interações planta-bactéria resultam de um reconhecimento recíproco de ambas espécies. Estas interações são responsáveis por processos biológicos essenciais para o desenvolvimento e a proteção das plantas. Este trabalho revisa as metodologias aplicadas na investigação de alterações nas comunidades bacterianas associadas às plantas. Uma descrição das técnicas é feita, desde o isolamento até a aplicação de técnicas independentes de cultivo, destacando as técnicas de qPCR, Gel de Eletroforese em Gradiente Desnaturante (DGGE), construção e análise de bibliotecas de clones, a aplicação de análise multivariada em dados de ecologia microbiana, e as novas metodologias de alto processamento de amostras como microarranjos e pirosequenciamento. Em resumo, esta revisão fornece informações sobre o desenvolvimento das técnicas tradicionais e uma visão geral sobre as novas tendências dos estudos de comunidades bacterianas associadas às plantas.

Dini-Andreote, F; Andreote, FD; Araújo, WL; Trevors, JT; van Elsas, JD. Bacterial genomes: habitat specificity and uncharted organisms. Microbial Ecology, v. 64, p. 1-7, 2012. (Doc. VII1.38)

Abstract: The capability and speed in generating genomic data have increased profoundly since the release of the draft human genome in 2000. Additionally, sequencing costs have continued to plummet as the next generation of highly efficient sequencing technologies (next-generation sequencing) became available and commercial facilities promote market competition. However, new challenges have emerged as researchers attempt to efficiently process the massive amounts of sequence data being generated. First, the described genome sequences are unequally distributed among the branches of bacterial life and, second, bacterial pan-genomes are often not considered when setting aims for sequencing projects. Here, we propose that scientists should be concerned with attaining an improved equal representation of most of the bacterial tree of life organisms, at the genomic level. Moreover, they should take into account the natural variation that is often observed within bacterial species and the role of the often changing surrounding environment and natural selection pressures, which is central to bacterial speciation and 
genome evolution. Not only will such efforts contribute to our overall understanding of the microbial diversity extant in ecosystems as well as the structuring of the extant genomes, but they will also facilitate the development of better methods for (meta)genome annotation.

Pylro, VS; Roesch, LFW; Ortega, JM; Amaral, AM; Tótola, MR; Hirsch, PR; Rosado, AS; GóesNeto, A; Silva, A; Rosa, CA; Morais, DK; Andreote, FD; Duarte, GF; Melo, IS; Seldin, L; Lambais, MR; Hungria, M; Peixoto, RS; Kruger, RH; Tsai, SM; Azevedo, V. Brazilian Microbiome Project: revealing the unexplored microbial diversity challenges and prospects. Microbial Ecology, v. 67, p. 237-241, 2014. (Doc. VII-1.58)

Abstract: The Brazilian Microbiome Project (BMP) aims to assemble a Brazilian Metagenomic Consortium/Database. At present, many metagenomic projects underway in Brazil are widely known. Our goal in this initiative is to co-ordinate and standardize these together with new projects to come. It is estimated that Brazil hosts approximately $20 \%$ of the entire world's macroorganism biological diversity. It is 1 of the 17 countries that share nearly $70 \%$ of the world's catalogued animal and plant species, and is recognized as one of the most megadiverse countries. At the end of 2012, Brazil has joined GBIF (Global Biodiversity Information Facility), as associated member, to improve the access to the Brazilian biodiversity data in a free and open way. This was an important step toward increasing international collaboration and clearly shows the commitment of the Brazilian government in directing national policies toward sustainable development. Despite its importance, the Brazilian microbial diversity is still considered to be largely unknown, and it is clear that to maintain ecosystem dynamics and to sustainably manage land use, it is crucial to understand the biological and functional diversity of the system. This is the first attempt to collect and collate information about Brazilian microbial genetic and functional diversity in a systematic and holistic manner. The success of the BMP depends on a massive collaborative effort of both the Brazilian and international scientific communities, and therefore, we invite all colleagues to participate in this project.

\section{SESSÃo I}

Fracetto, GGM; Azevedo, LCB; Fracetto, FJC; Andreote, FD; Lambais, MR; Pfenning, LH. Impact of amazon land use on the community of soil fungi. Scientia Agrícola, v. 70, p. 59-67, 2013. (Doc.

\section{VII-1.46)}

Abstract: Considered as one of the most biodiverse biomes, the Amazon has a featured role in the discovery of new species of plants, animals and microorganisms, which may be important for the functionality of different ecosystems. However, studies on the impacts resulted from changes in the Amazon land use on microbial communities and their functions are still limited. In this context, the soil fungal diversity can act as an important indicator of environmental stress caused by land use of the Amazon. This study describes changes in soil fungal communities caused by different systems of land use (primary forest, secondary forest, agroforestry, agriculture and pasture). Communities were observed in each of the areas using denaturing gradient gel electrophoresis (DGGE) of $18 \mathrm{~S}$ rRNA gene combined with the non-metric 
multidimensional scaling (NMDS). Unique bands indicated the dominance of particular fungal groups in each of the specific treatments, mainly in areas converted to pasture, which differed greatly from samples of other systems of land use (SLU). The analysis of partial sequence of the 18S rRNA gene of fungi in soils under primary forest, agriculture and pasture showed differences $(\mathrm{p}=0.001)$, evidencing the fungal community response to such changes. Most abundant phyla were the Zygomycota in the soil under primary forest and agricultural land, and Basidiomycota in the soil under pasture. The results show that the Amazon soil is an ecosystem susceptible to environmental changes in regarding the fungi community inhabiting this niche.

Kavamura, VN; Taketani, RG; Lançoni, MD; Andreote, FD; Mendes, R; Melo, IS. Water Regime Influences Bulk soil and rhizosphere of Cereus jamacaru bacterial communities in the Brazilian caatinga biome. Plos One, v. 8, p. e73606, 2013a. (Doc. VII-1.54)

Abstract: We used the T-RFLP technique combined with Ion Torrent (PGM) sequencing of 16S rRNA and multivariate analysis to study the structure of bulk soil and rhizosphere bacterial communities of a cactus, Cereus jamacaru, from the Brazilian Caatinga biome, which is unique to Brazil. The availability of water shapes the rhizosphere communities, resulting in different patterns during the rainy and dry seasons. Taxonomic approaches and statistical analysis revealed that the phylum Actinobacteria strongly correlated with the dry season, while samples from the rainy season exhibited a strong correlation with the phylum Proteobacteria for rhizosphere samples and with the phyla Bacteroidetes, Firmicutes, Lentisphaerae, and Tenericutes for bulk soil samples. The STAMP software also indicated that the phylum Bacteroidetes, as well as two classes in the Proteobacteria phylum ( $c$ and d), were the most significant ones during the rainy season. The average abundance of the phylum Actinobacteria and the genus Bacillus was significantly greater during the dry season. Some significant genera found during the dry season might reflect their tolerance to the extreme conditions found in the Caatinga biome. They may also indicate the ecological function that microorganisms play in providing plants with some degree of tolerance to water stress or in assisting in their development through mechanisms of growth promotion. Alterations in microbial communities can be due to the different abilities of native microorganisms to resist and adapt to environmental changes.

Kavamura, VN; Santos, SN; Silva, JL; Parma, MM; Avila, LA; Visconti, A; Zucchi, TD; Taketani, RG; Andreote, FD; Melo, IS. Screening of Brazilian cacti rhizobacteria for plant growth promotion under drought. Microbiological Research, v. 168, p. 183-191, 2013b. (Doc. VII-1.47)

Abstract: Drought is one of the major problems worldwide. The search for new and efficient microorganisms, from unexplored environments, to be used in association with plants to alleviate the negative effects imposed by water stress, is an interesting alternative. Thus, cacti-associated bacteria from the Brazilian semi-arid region were isolated based on their ability to grow in medium with reduced water availability. Strains were tested for the production of exopolysaccharides (EPS), as well as in vitro plant growth promotion traits. A great proportion of the isolates belong to the genus Bacillus. From a total of fortyeight bacteria, 65\% were able to grow in medium with reduced water availability (0.919Aw), exopolysaccharide production was observed for $65 \%$ of the strains. The production of indole acetic acid 
(IAA) exceeding $51 \mathrm{gmL}^{-1}$ was observed for $4 \%$ and the high solubilization of $\mathrm{Ca}-\mathrm{P}$ was verified for $6 \%$ of the isolates. No strain was able to produce hydrogen cyanide ( $\mathrm{HCN}), 71 \%$ produced ammonia and $79 \%$ showed a halo of carboxymethyl cellulose (CMC) degradation. Zea mays L. growth promotion under water stress (30\% of field capacity) was achieved by two strains of Bacillus spp. This is the first report to describe cacti-associated bacteria from Brazilian semi-arid with plant growth-promoting abilities.

Santos, SN; Kavamura, VN; Silva, JL; Melo, IS; Andreote, FD. Plant growth promoter rhizobacteria in plants inhabiting harsh tropical environments and its role in agricultural improvements. In: Dinesh K Maheshwari. (Org.). Plant Growth and Health Promoting Bacteria. Ied.Berlim: Springer-Verlag, 2010, v. 1, p. 251-272. (Doc. VII-3.5)

Abstract: The importance of the interactions between plants and bacteria is well known for plant development and success of agriculture. A number of succeeded examples are reported in the literature for the improvement of plant yields and protection against pathogens and pests. However, some specific niches where these interactions are essential are still unexplored, like the environments where the agriculture is not practiced due to the harsh conditions found; mangroves and the Brazilian semiarid caatinga. Digging into the bacterial diversity associates to plant growth promotion in such spots can help on the description of new species and features related to the plant growth-promoting rhizobacteria character under harsh tropical conditions. This chapter gives an overview of examples of such niches, where the bacterial community must be adapted to survive and support the plant development. Possible bacterial characteristics related to this ability will be discussed, as the production of biofilms and exopolysaccharides. Furthermore, the application of these biotechnological products will be evaluated and discussed allowing the reader to have a snapshot on this yet non-explored biodiversity.

Santos, SN; Kavamura, VN; Castanha, RF; Andreote, FD; Carvalho, JE; Queiroz, SCN; Melo, IS. Antitumoral, antioxidant and antimicrobial molecules from Combretum rupicola. International Journal of Pharma and Bio Sciences, v. 4, p. 422-428, 2013. (Doc. VII-1.45)

Abstract: This investigation describes the anticancer, antioxidant and antimicrobial properties of the extracts of Combretum rupicola, a native plant from Northeast of Brazil. Methanolic, ethyl acetate and chloroform extracts from leaves of $C$. rupicola were evaluated in relation to their potential in inhibiting the cell growth and cytotoxic properties against nine human cancer cell lines (MCF-7, NCI-ADR/RES, OVCAR-3, PC3, HT-29, NCIH460, 786-O, UACC-62, K-562). In addition, antioxidant activity of these extracts was measured using DPPH as radical scavenging assay and the antimicrobial activities against nine pathogens were tested by agar diffusion method. Preliminary results showed that the this plant demonstrates to have moderate activity against bacteria but, on the other side, the extracts showed significant anticancer activities against four cell lines and the most significant activity was observed against MCF-7 (65.9 ug $\mathrm{mL}^{-1}$ ), highest inhibitory concentration IC50 $0.22 \mathrm{ug} \mathrm{mL}^{-1}$ for antioxidant activity. These founds are the first scientific reports on secondary metabolites with biological activities of $C$. rupicola, suggesting the potential of this botanic species for pharmaceutical industry. 
Julia Elidia Lima. Diversidade de bactérias e arquéias em solos da mata atlântica. 2012. Mestrado em Microbiologia Agrícola, Escola Superior de Agricultura Luiz de Queiroz - USP. Bolsista CNPq. (Doc. XI.1.2.3)

Resumo: A Mata Atlântica é um bioma constituído de vários ecossistemas e considerado um hotspot da biodiversidade mundial. Seu extensão vai do Rio Grande do Sul até o Piauí, compondo cerca de $15 \%$ do território nacional. Porém, aproximadamente $93 \%$ da formação original da Mata atlântica já foi devastada. Seus solos são comumente pobres (baixa disponibilidade de nutrientes), mas apresenta alta taxa de decomposição do material orgânico, baixas perdas de nutrientes por lixiviação e grande ciclagem de nutrientes. Portanto, esse ambiente é composto por comunidades microbianas complexas e eficientes nestes processos, apesar de seu papel delas ser ainda pouco descrito. Desta maneira, no presente trabalho foram avaliados vários fatores que estão diretamente relacionados com a composição da comunidade de bactérias e arquéias em três áreas presentes num gradiente altitudinal de Mata Atlântica; Santa Virgínia, Picinguaba e Restinga. Com base em análises independentes de cultivo, foi demonstrado por PCR-DGGE que a estruturação da comunidade de bactérias e arquéias nestas áreas é mais dependente da vegetação do que das características físicas e químicas do solo. Adicionalmente, a abundância de tais comunidades, determinada por qPCR, mostrou-se similar nas três áreas amostradas, com valores de $10^{9} \mathrm{e} 10^{8}$ cópias do gene ribossomal 16S DNAr de bactérias e arquéias, respectivamente. Em relação aos grupos taxonômicos presentes em tais áreas, bactérias mostraram-se predominantemente pertencentes aos filos Acidobacteria, Verrucomicrobia e Proteobacteria (com destaque para Acidobacteria, que foi o grupo dominante com média de 55,9\%), e arquéias foram semelhantes aos grupos Euryarchaeota e Crenarchaeota, com destaque para Crenarchaeota que compôs uma média de $84 \%$. Mais detalhadamente, pode-se observar diferenças na composição das comunidades das três áreas estudadas, com uma maior frequência de Acidobacteria em na área de Picinguaba e Crenarchaeota em Santa Virgínia. Desta forma, este trabalho mostrou de forma pioneira, a detalhada composição da comunidade de Bacteria e Archaea em solos de Mata Atlântica, destacando alterações nestas comunidades devido às diferenciações nas características das áreas, principalmente guiadas pela composição florística da vegetação.

\section{Emiliana Manesco Romagnoli. Diversidade de arquéias amônio-oxidantes em solos de mata} atlântica do estado de São Paulo. 2012. Mestrado em Microbiologia Agrícola, Escola Superior de Agricultura Luiz de Queiroz - USP. Bolsista Capes. (Doc. XI.1.2.4)

Resumo: A estrutura das comunidades de arquéias e bactérias amônio oxidantes (AOA e AOB, respectivamente) e de bactéria fixadoras de nitrogênio de vida livre (BFNVL) foi avaliada em amostras de solo coletadas em três áreas de Mata Atlântica do Estado de São Paulo (Santa Virgínia, Picinguaba e Restinga) por meio de metodologias independentes de cultivo. Após a extração do DNA do solo, o perfil das comunidades de AOA, AOB e BFNVL foi acessado por PCR-DGGE e seus respectivos genes, amoA, 16S DNAr e nifH, quantificados por meio de qPCR. Além disso, foi realizado o pirosequenciamento do gene 16S DNAr da região V3 em arquéias e da região V4 de bactérias. Os dados foram submetidos às análises de redundância (RDA) e similaridade (ANOSIM) e ao teste de Mantel. Foram observadas diferenças significativas na estrutura das comunidades de AOA, AOB e BFNVL, sugerindo que a cobertura vegetal, assim como os atributos físico-químicos do solo, influencia a atividade destes micro- 
organismos nas três áreas. Santa Virgínia e Picinguaba apresentaram maior abundância de AOA e AOB, sendo AOA proporcionalmente mais abundante do que AOB em todas as áreas. Já as comunidades de BFNVL foram mais abundantes em Santa Virgínia e Restinga. A diversidade das comunidades de Crenarchaeota foi similar entre as áreas, porém, Picinguaba revelou maior diversidade de unidades taxonômicas operacionais (UTOs). Este trabalho possibilitou uma primeira exploração da diversidade e abundância das comunidades de AOA, AOB e BFNVL nos solos de Mata Atlântica do Estado de São Paulo, sendo que as informações obtidas poderão auxiliar futuros estudos sobre o entendimento do papel destas comunidades no ciclo global do nitrogênio na Terra.

\section{SESSÃO II}

Dias, ACF; Andreote, FD; Rigonato, J; Fiore, MF; Melo, IS; Araújo, WL. The bacterial diversity in a Brazilian non-disturbed mangrove sediment. Antonie van Leeuwenhoek, v. 98, p. 541-551, 2010. (Doc. VII-1.20)

Abstract: The bacterial diversity present in sediments of a well-preserved mangrove in Ilha do Cardoso, located in the extreme south of São Paulo State coastline, Brazil, was assessed using culture-independent molecular approaches (denaturing gradient gel electrophoresis (DGGE) and analysis of 166 sequences from a clone library). The data revealed a bacterial community dominated by Alphaproteobacteria (40.36\% of clones), Gammaproteobacteria (19.28\% of clones) and Acidobacteria (27.71\% of clones), while minor components of the assemblage were affiliated to Betaproteobacteria, Deltaproteobacteria, Firmicutes, Actinobacteria and Bacteroidetes. The clustering and redundancy analysis (RDA) based on DGGE were used to determine factors that modulate the diversity of bacterial communities in mangroves, such as depth, seasonal fluctuations, and locations over a transect area from the sea to the land. Profiles of specific DGGE gels showed that both dominant ('universal' Bacteria and Alphaproteobacteria) and low-density bacterial communities (Betaproteobacteria and Actinobacteria) are responsive to shifts in environmental factors. The location within the mangrove was determinant for all fractions of the community studied, whereas season was significant for Bacteria, Alphaproteobacteria, and Betaproteobacteria and sample depth determined the diversity of Alphaproteobacteria and Actinobacteria.

Dias, ACF; Dini-Andreote, F; Taketani, RG; Tsai, SM; Azevedo, JL; Melo, IS; Andreote, FD. Archaeal communities in the sediments of three contrasting mangroves. Journal of Soils and Sediments, v. 11, p. 1466-1476, 2011. (Doc. VII-1.28)

Abstract: Purpose: This study evaluates the presence and diversity of 16S rRNA (rrs) and amoA genes from archaea in three mangrove sediments under different stages of preservation (one pristine mangrove, one affected by anthropogenic activity, and another contaminated by an oil spill) in the state of São Paulo (Brazil). Materials and methods: A combination of DGGE, coupled with ordination analysis, and clone libraries of both targeted genes ( $r r s$ and $a m o A$ ) was used to infer the diversity and phylogeny of archaeal communities in the mangrove analyzed samples. Results and discussion: The DGGE combined with multivariate analysis revealed, based on the ribosomal gene, differences in archaeal communities 
according to environmental parameters such as mangrove location, anthropogenic activity, and oil contamination. The profiles based on the amoA gene were more similar than those obtained for the gene rrs, with the only difference statistically observed for the community found in the mangrove under anthropogenic pressure. Furthermore, phylogenetic analysis revealed most archaeal groups affiliated to sequences belonging to the Thaumarchaeota (53.1\%, 24 OTUs) and Euryarchaeota (29.6\%, 14 OTUs) phyla, in addition to 14 sequences affiliated to an unclassified Archaea (16.1\%, 8 OTUs). Concerning the analysis of the $a m o A$ gene, mangroves harbored sequences affiliated with those previously described in water column and soil/sediment samples, besides two possible clusters specifically found in mangroves. Conclusions: The findings are that the mangroves act as a reservoir for archaeal diversity, are possibly involved in nitrogen transformation in this ecosystem, and are affected by distinct pressures caused by anthropogenic activities.

Fasanella, CC; Dias, ACF; Rigonato, J; Fiore, MF; Soares Jr, FL; Melo, IS; Pizzirani-Kleiner, AA; van Elsas, JD; Andreote, FD. The selection exerted by oil contamination on mangrove fungal communities. Water, Air and Soil Pollution, v. 223, p. 4233-4243, 2012. (Doc. VII-1.40)

Abstract: Mangrove ecosystems are tropical environments that are characterized by the interaction between the land and the sea. As such, this ecosystem is vulnerable to oil spills. Here, we show a cultureindependent survey of fungal communities that are found in the sediments of the following two mangroves that are located on the coast of Sao Paulo State (Brazil): (1) an oil-spill-affected mangrove and (2) a nearby unaffected mangrove. Samples were collected from each mangrove forest at three distinct locations (transect from sea to land), and the samples were analyzed by quantitative PCR and internal transcribed spacer (ITS)-based PCR-DGGE analysis. The abundance of fungi was found to be higher in the oil-affected mangrove. Visual observation and correspondence analysis (CA) of the ITS-based PCRDGGE profiles revealed differences in the fungal communities between the sampled areas. Remarkably, the oil-spilled area was quite distinct from the unaffected sampling areas. On the basis of the ITS sequences, fungi that are associated with the Basidiomycota and Ascomycota taxa were most common and belonged primarily to the genera Epicoccum, Nigrospora, and Cladosporium. Moreover, the Nigrospora fungal species were shown to be sensitive to oil, whereas a group that was described as "uncultured Basidiomycota" was found more frequently in oil-contaminated areas. Our results showed an increase in fungal abundance in the oil-polluted mangrove regions, and these data indicated potential fungal candidates for remediation of the oil-affected mangroves.

Andreote, FD; Jimenez, DJ; Chaves, D; Dias, ACF; Luvizotto, DM; Dini-Andreote, F; Fasanella, CC; Baena, S; Lopez, MV; Taketani, RG; Melo, IS. The microbiome of Brazilian mangrove sediments as revealed by metagenomics. Plos One, v. 7, p. e38600, 2012. (Doc. VII-1.42)

Abstract: Here we embark in a deep metagenomic survey that revealed the taxonomic and potential metabolic pathways aspects of mangrove sediment microbiology. The extraction of DNA from sediment samples and the direct application of pyrosequencing resulted in approximately $215 \mathrm{Mb}$ of data from four distinct mangrove areas (BrMgv01 to 04) in Brazil. The taxonomic approaches applied revealed the dominance of Deltaproteobacteria and Gammaproteobacteria in the samples. Paired statistical analysis showed higher 
proportions of specific taxonomic groups in each dataset. The metabolic reconstruction indicated the possible occurrence of processes modulated by the prevailing conditions found in mangrove sediments. In terms of carbon cycling, the sequences indicated the prevalence of genes involved in the metabolism of methane, formaldehyde, and carbon dioxide. With respect to the nitrogen cycle, evidence for sequences associated with dissimilatory reduction of nitrate, nitrogen immobilization, and denitrification was detected. Sequences related to the production of adenylsulfate, sulfite, and $\mathrm{H}_{2} \mathrm{~S}$ were relevant to the sulphur cycle. These data indicate that the microbial core involved in methane, nitrogen, and sulphur metabolism consists mainly of Burkholderiaceae, Planctomycetaceae, Rhodobacteraceae, and Desulfobacteraceae. Comparison of our data to datasets from soil and sea samples resulted in the allotment of the mangrove sediments between those samples. The results of this study add valuable data about the composition of microbial communities in mangroves and also shed light on possible transformations promoted by microbial organisms in mangrove sediments.

\section{Maryiemy Varón Lopez. Descrição da microbiota relacionada às transformações do enxofre em} sedimentos de manguezais. 2013. Doutorado em Microbiologia Agrícola, Escola Superior de Agricultura Luiz de Queiroz - USP. Bolsista Capes. (Doc. XI.1.1.2)

Resumo: Os manguezais são ambientes de transição entre os ecossistemas terrestres e marinhos, essenciais para o crescimento e desenvolvimento de muitas espécies de elevado interesse ecológico e econômico. Apesar de ter sua importancia reconhecida, são constantemente impactados por diversos poluentes que influenciam sua estabilidade. Estes ecossistemas caracterizam-se por ser anaeróbicos, ricos em sulfato e em matéria orgânica, onde os microrganismos são fundamentais na ciclagem de nutrientes, em especial os envolvidos no ciclo do enxofre, onde as Procariotas redutoras de sulfato (sulphate-reducing prokaryotes, SRB) aparecem como um grupo frequente e com um papel preponderante. O presente estudo mostrou que as comunidades de arquéias, bactérias e SRB são abundantes, diversas e responsivas aos estados de intervenção dos manguezais. A abundância medida por qPCR mostrou que as arquéias e bactérias aumentam com a contaminação. A diversidade estudada por pirosequenciamento do gene ribossomal 16S DNAr, indicou que estes grupos são diversos, mostrando filos Euryarcheota e Crenarcheota do domínio Archaea, e os filos Deltaproteobacteria e Gammaproteobacteria do domínio Bacteria, como grupos frequentes. A estrutura destas comunidades, avaliada por análises de coocorrência, revelou que a microbiota responde à contaminação, diminuindo e simplificando as interações quanto maior a contaminação. A diversidade dos grupos relacionados ao ciclo do enxofre estudada por DGGE (aprA e $d s r B$ ), pirosequenciamento ( $d s r B$ ) e GeoChip ( $a p r A, d s r B$ ), mostraram que a classe Deltaproteobacteria com as ordens Desulfobacterales e Desulfovibrionales são o grupo prevalente na redução do sulfato e as classes Gammaproteobacteria e Betaproteobacteria na oxidação do enxofre (sulphur-oxidising - SOB). O GeoChip $(a p r A, d s r B)$ foi a única metodologia que permitiu detectar arquéias redutoras de sulfato (gênero Archaeoglobus e Pyrobaculum), sendo este o primeiro reporte em ecossistemas de manguezais. Deste modo, estes resultados evidenciam que a microbiota em áreas de manguezais responde à contaminação, possuindo uma alta frequência de SRB e SOB, ressaltando assim a importância do ciclo do enxofre em ambientes de manguezais. 
Juliana Eschlooz de Araújo. Detecção e análise de sequências de Planctomycetes em metagenomas de manguezais. Mestrado em Microbiolgia Agrícola, Escola Superior de Agricultura Luiz de Queiroz - USP. Bolsista FAPESP. (Doc. XI.1.2.9)

Resumo: Os manguezais são considerados um ecossistema único, devido sua particular combinação de condições ambientais, influenciados pela sua localização na interface entre o continente e oceano. $\mathrm{O}$ estudo deste ecossistema se torna urgente uma vez que os manguezais estão desaparecendo em todo mundo, e sua diversidade de grupos microbianos é ainda pouco conhecida. Dentro dessa temática, o presente projeto visa descrever a possível funcionalidade de bactérias pertencentes ao filo Planctomycetes nos manguezais. Tais organismos são ainda pouco estudados, de difícil cultivo, sendo obtidos principalmente em ambientes marinhos, tratamento de água e locais de criação de peixes. Dentro desse filo são encontrados microrganismos pertencentes a gêneros descritos como capazes de realizar a oxidação anaeróbica do íon amônio (anammox), uma importante transformação do nitrogênio em ambientes com baixa disponibilidade de oxigênio. E ainda, visamos descrever a possível funcionalidade de bactérias pertencentes ao filo Planctomycetes nos manguezais. Para isso, foi inicialmente realizada uma comparação dos genomas de Planctomycetes com as sequências obtidas por análises de metagenômica e metatranscriptômica, onde foram encontradas sequências similares às afiliadas a funções desconhecidas (putative protein) e a sulfatases. Tais enzimas são descritas como hidrolíticas, que catalizam a clivagem de ésteres de sulfato, liberando o enxofre na forma assimilável. A análise de sequências de uma biblioteca metagenômica (obtida de um manguezal contaminado com petróleo) permitiu a visualização de fragmentos genômicos de Planctomycetes. Esta análise revelou também a ocorrência de genes relacionados a produção de sulfatases, além de indicar arranjos gênicos distintos dos descritos nos genomas de organismos deste grupo, possivelmente indicando a ocorrência de endemismo de Planctomycetes em manguezais. Esta observação foi reforçada pelo cultivo de isolados afiliados a este grupo, os quais tiveram sua afiliação confirmada pelo sequenciamento parcial do gene ribossomal $16 \mathrm{~S}$ DNAr. Alguns destes isolados formaram clusters diferenciados dentro do filo Planctomycetes, indicando que podem ser estes novas espécies. Sendo assim, a caracterização desse grupo de microrganismos numa combinação de análises in silico e in vivo, possibilitou a confirmação da ocorrência de tais organismos nos manguezais, e gerou as primeiras informações sobre sua funcionalidade neste sistema, onde parece ocorrer de forma diferenciada aos demais ambientes onde já foram descritos.

Taketani, RG; Yoshiura, CA; Dias, ACF; Andreote, FD; Tsai, SM. Diversity and identification of methanogenic archaea and sulphate-reducing bacteria in sediments from a pristine tropical mangrove. Antonie van Leeuwenhoek, v. 97, p. 401-411, 2010. (Doc. VII-1.22)

Abstract: Mangrove sediments are anaerobic ecosystems rich in organic matter. This environment is optimal for anaerobic microorganisms, such as sulphate-reducing bacteria and methanogenic archaea, which are responsible for nutrient cycling. In this study, the diversity of these two functional guilds was evaluated in a pristine mangrove forest using denaturing gradient gel electrophoresis (DGGE) and clone library sequencing in a $50 \mathrm{~cm}$ vertical profile sampled every $5.0 \mathrm{~cm}$. DGGE profiles indicated that both groups presented higher richness in shallow samples $(0-30 \mathrm{~cm})$ with a steep decrease in richness beyond that depth. According to redundancy analysis, this alteration significantly correlated with a decrease in the 
amount of organic matter. Clone library sequencing indicated that depth had a strong effect on the selection of dissimilatory sulphate reductase $(d s r B)$ operational taxonomic units (OTUs), as indicated by the small number of shared OTUs found in shallow $(0.0 \mathrm{~cm})$ and deep $(40.0 \mathrm{~cm})$ libraries. On the other hand, methyl coenzyme-M reductase ( $m c r A$ ) libraries indicated that most of the OTUs found in the shallow library were present in the deep library. These results show that these two guilds co-exist in these mangrove sediments and indicate important roles for these organisms in nutrient cycling within this ecosystem.

Dias, ACF; Pereira e Silva, MDC; Cotta, SR; Dini-Andreote, F; Soares Jr, FL; Salles, JF; Azevedo, JL; van Elsas, JD; Andreote, FD. Abundance and genetic diversity of nifH gene sequences in anthropogenically affected Brazilian mangrove sediments. Applied and Environmental Microbiology, v. 78, p. 7960-7967, 2012. (Doc. VII-1.43)

Abstract: Although mangroves represent ecosystems of global importance, the genetic diversity and abundance of functional genes that are key to their functioning scarcely have been explored. Here, we present a survey based on the nifH gene across transects of sediments of two mangrove systems located along the coast line of São Paulo state (Brazil) which differed by degree of disturbance, i.e., an oil-spillaffected and an unaffected mangrove. The diazotrophic communities were assessed by denaturing gradient gel electrophoresis (DGGE), quantitative PCR (qPCR), and clone libraries. The nifH gene abundance was similar across the two mangrove sediment systems, as evidenced by qPCR. However, the nifH-based PCR-DGGE profiles revealed clear differences between the mangroves. Moreover, shifts in the nifH gene diversities were noted along the land-sea transect within the previously oiled mangrove. The nifH gene diversity depicted the presence of nitrogen-fixing bacteria affiliated with a wide range of taxa, encompassing members of the Alphaproteobacteria, Betaproteobacteria, Gammaproteobacteria, Firmicutes, and also a group of anaerobic sulfate-reducing bacteria. We also detected a unique mangrovespecific cluster of sequences denoted Mgv-nifH. Our results indicate that nitrogen-fixing bacterial guilds can be partially endemic to mangroves, and these communities are modulated by oil contamination, which has important implications for conservation strategies.

Varon-Lopez, M; Dias, ACF; Fasanella, CC; Durrer, A; Melo, IS; Kuramae, EE; Andreote, FD. Sulphur-oxidising and sulphate-reducing communities in Brazilian mangrove sediments. Environmental Microbiology, v. 16, p. 845-855, 2014. (Doc. VII-1.59)

Abstract: Mangrove soils are anaerobic environments rich in sulphate and organic matter. Although the sulphur cycle is one of the major actors in this ecosystem, little is known regarding the sulphur bacteria communities in mangrove soils. We investigated the abundance, composition and diversity of sulphuroxidizing (SOB) and sulphate-reducing (SRB) bacteria in sediments from three Brazilian mangrove communities: two contaminated, one with oil (OilMgv) and one with urban waste and sludge (AntMgv), and one pristine (PrsMgv). The community structures were assessed using quantitative real-time polymerase chain reaction (qPCR), polymerase chain reaction denaturing gradient gel electrophoresis (PCR-DGGE) and clone libraries, using genes for the enzymes adenosine-5'-phosphosulphate reductase (aprA) and sulphite reductase (Dsr) $(d s r B)$. The abundance for qPCR showed the ratio $d s r B / a p r A$ to be 
variable among mangroves and higher according to the gradient observed for oil contamination in the OilMgv. The PCR-DGGE patterns analysed by Nonmetric Multidimensional Scaling revealed differences among the structures of the three mangrove communities. The clone libraries showed that Betaproteobacteria, Gammaproteobacteria and Deltaproteobacteria were the most abundant groups associated with sulphur cycling in mangrove sediments. We conclude that the microbial SOB and SRB communities in mangrove soils are different in each mangrove forest and that such microbial communities could possibly be used as a proxy for contamination in mangrove forests.

\section{Armando Cavalcante Franco Dias. Diversidade de arquéias e bactérias envolvidas na ciclagem do} nitrogênio em sedimentos de manguezais. 2012. Doutorado em Biologia na Agricultura e no Ambiente, Centro de Energia Nuclear na Agricultura - USP. Bolsista FAPESP. Co-orientador. (Doc. XI.1.1.1)

Resumo: O manguezal é um ecossistema costeiro, localizado em regiões de interface entre os ambientes terrestre e marinho, de ocorrência exclusiva em zonas tropicais e subtropicais. Esta localização confere ao solo deste ambiente características únicas, como alta salinidade e baixa disponibilidade de oxigênio, associado a grande riqueza em matéria orgânica. O resultado destas condições é a ocorrência de uma restrita diversidade de plantas em tais ambientes, associada a uma grande diversidade de animais, que usam o manguezal para sua proteção e reprodução. O presente estudo mostrou como as comunidades de arquéias (amoA e 16S DNAr) e bactérias (nifH e 16S DNAr) estão estruturadas em solos de manguezais sob distintos estados de preservação. Os perfis de DGGE indicaram alterações na composição das comunidades alvo, ligando sua estruturação com a contaminação do ambiente, enquanto que as quantificações de tais genes por meio de PCR quantitativo em tempo real (qPCR) indicaram alterações apenas na comunidade de arquéias oxidadoras de amônio. A filogenia destes grupos revelou a presença de grupos comumente encontrados em solos e água, além de grupos particulares, possivelmente relacionado ao processo de especiação no ambiente de manguezal. De maneira geral, os resultados indicam que as comunidades de arquéias e bactérias são responsivas ao estado de contaminação dos manguezais, o que pode gerar um processamento diferencial do nitrogênio nestes solos.

Dias, ACF; Andreote, FD; Dini-Andreote, F; Lacava, PT; Sá, ALB; Melo, IS; Azevedo, JL; Araújo, WL. Diversity and biotechnological potential of culturable bacteria from Brazilian mangrove sediment. World Journal of Microbiology and Biotechnology, v. 25, p. 1305 - 1311, 2009. (Doc. VII-1.15)

Abstract: Mangrove ecosystems are environments subject to substantial degradation by anthropogenic activities. Its location, in coastal area, interfacing the continents and the oceans makes it substantially important in the prospection for biotechnological applications. In this study, we assessed the diversity of culturable bacteria present over the seasons at two depths $(0-10$ and $30-40 \mathrm{~cm})$ in a mangrove sediment and in a transect area from the land to the sea. In total, 238 bacteria were isolated, characterized by Amplified Ribosomal DNA Restriction Analysis (ARDRA) and further identified, by Fatty Acid Methyl Esther (FAME-MIDI), into the orders of Vibrionales, Actinomycetales and Bacillales. Also the ability of 
the isolates in producing economically important enzymes (amylases, proteases, esterases and lipases) was evaluated and the order Vibrionales was the main enzymatic source.

\section{Fábio Lino Soares Júnior. Isolamento e caracterização de bactérias celulolíticas de ambientes} extremos. 2011. Mestrado em Biotecnologia, Universidade de Mogi das Cruzes. Sem bolsa. (Doc. XI.1.2.1)

Resumo: Ambientes extremos são considerados locais de residência de comunidades microbianas particulares, as quais sobrevivem à ação das condições ambientais, comumente inóspitas como temperaturas extremas, altos teores de salinidade e altos níveis de radiação. As bactérias extremófilas possuem a habilidade de reproduzir-se nestas condições, onde atuam na ciclagem de matéria orgânica e de nutrientes. Este trabalho visa avaliar e caracterizar isolados bacterianos com atividade celulolítica em amostras de solo da Antártica (Estação Antártica Comandante Ferraz), da Caatinga brasileira (Nordeste brasileiro) e de sedimentos de Manguezais (Ilha do Cardoso, SP). Amostras destes ambientes foram submetidas a enriquecimento em dois meios de cultura [caldo de triptona (TSB) 5\% e meio mínimo de sais (MM)], contendo como agente de seleção a adição $10 \%$ de celulose em pó. Alíquotas foram coletadas dos enriquecimentos e a inoculação em novos meios de cultivo foram feitas nos períodos de $0 ; 3 ; 6 ; 12$ e 24 dias, sendo que nos períodos de 12 e 24 dias foram realizados isolamentos de colônias no mesmo meio de cultivo suplementado com ágar (1.5\%). Coleções de aproximadamente 30 colônias de cada meio de cultivo foram coletadas para os testes posteriores. Tais isolados foram submetidos às análises de fingerprinting genômico por BOX-PCR, identificação por sequenciamento parcial do gene 16S rDNA e atividade celulolítica (endoglucanases e exoglucanases). Desta forma, este projeto tem como objetivo acessar grupos bacterianos presentes em distintos ambientes (solo da Antártica, solo da caatinga brasileira e sedimento de manguezais), dando enfoque para aqueles que apresentam a capacidade de atuar em algum passo do processo de degradação da celulose.

Soares Jr, FL; Dias, ACF; Fasanella, CC; Taketani, RG; Lima, AOS; Melo, IS. Endo- and exoglucanase activities in bacteria from mangrove sediment. Brazilian Journal of Microbiology, v. 44, p. 696-976, 2013 (Doc. VII.1.55).

Abstract: The mangrove ecosystem is an unexplored source for biotechnological applications. In this unique environment, endemic bacteria have the ability to thrive in the harsh environmental conditions (salinity and anaerobiosis), and act in the degradation of organic matter, promoting nutrient cycles. Thus, this study aimed to assess the cellulolytic activities of bacterial groups present in the sediment from a mangrove located in Ilha do Cardoso (SP, Brazil). To optimize the isolation of cellulolytic bacteria, enrichments in two types of culture media (tryptone broth and minimum salt medium), both supplemented with $5 \% \mathrm{NaCl}$ and $1 \%$ of cellulose, were performed. Tests conducted with the obtained colonies showed a higher occurrence of endoglycolytic activity (33 isolates) than exoglycolytic (19 isolates), and the degradation activity was shown to be modulated by the presence of $\mathrm{NaCl}$. The isolated bacteria were clustered by BOX-PCR and further classified on the basis of partial 16S rRNA sequences as Alphaproteobacteria, Gammaproteobacteria, Actinobacteria, Firmicutes or Bacteroidetes. Therefore, this 
study highlights the importance of studies focusing on the endemic species found in mangroves to exploit them as novel biotechnological tools for the degradation of cellulose.

\section{SESSÃo III}

Dini-Andreote, F; Andreote, FD; Costa, R; Taketani, RG; Elsas, JD; Araújo, WL. Bacterial soil community in a Brazilian sugarcane field. Plant and Soil, v. 336, p. 337-349, 2010. (Doc. VII1.21)

Abstract: The assessment of bacterial communities in soil gives insight into microbial behavior under prevailing environmental conditions. In this context, we assessed the composition of soil bacterial communities in a Brazilian sugarcane experimental field. The experimental design encompassed plots containing common sugarcane (variety SP80-1842) and its transgenic form (IMI-1 — imazapyr herbicide resistant). Plants were grown in such field plots in a completely randomized design with three treatments, which addressed the factors transgene and imazapyr herbicide application. Soil samples were taken at three developmental stages during plant growth and analyzed using 16S ribosomal RNA (rRNA)-based PCR-denaturing gradient gel electrophoresis (PCR-DGGE) and clone libraries. PCR-DGGE fingerprints obtained for the total bacterial community and specific bacterial groups - Actinobacteria, Alphaproteobacteria and Betaproteobacteria - revealed that the structure of these assemblages did not differ over time and among treatments. Nevertheless, slight differences among 16S rRNA gene clone libraries constructed from each treatment could be observed at particular cut-off levels. Altogether, the libraries encompassed a total of eleven bacterial phyla and the candidate divisions TM7 and OP10. Clone sequences affiliated with the Proteobacteria, Actinobacteria, Firmicutes and Acidobacteria were, in this order, most abundant. Accurate phylogenetic analyses were performed for the phyla Acidobacteria and Verrucomicrobia, revealing the structures of these groups, which are still poorly understood as to their importance for soil functioning and sustainability under agricultural practices.

\section{Thiago Gumiére. Biogeografia da comunidade fúngica em solos com cultivo de cana-de-açúcar.} 2013. Mestrado em Solos e Nutrição de Plantas, Escola Superior de Agricultura Luiz de Queiroz - USP. Bolsista FAPESP. (Doc. XI.1.2.3)

Resumo: A cana-de-açúcar é atualmente a cultura de maior importância agrícola do Estado de São Paulo, a partir da qual são gerados açúcar e etanol, além de vários outros subprodutos. No entanto, com a expansão das fronteiras agrícolas e alterações nas práticas de manejo, ocorre atualmente um momento de adequação de tal cultivo, que visa uma maior produtividade e sustentabilidade de produção. Para isto, dentre outros fatores, o papel da comunidade microbiana presente nos solos pode ter fundamental importância, auxiliando no melhor desenvolvimento da planta. No entanto, pouco se sabe sobre a comunidade microbiana existente nos solos cultivados com cana-de-açúcar. Dessa forma, este trabalho teve como objetivo avaliar a diversidade e a abundância de fungos em solos de cultivo de cana-de-açúcar no estado de São Paulo, em áreas sob diferentes atributos químicos, físicos e de manejo. Objetivou-se também, 
verificar a ocorrência de padrões biogeográficos na estruturação de tais comunidades. Para isso, foi realizada a análise da estrutura das comunidades fúngicas por polimorfismo de comprimento de fragmentos de restrição terminal (T-RFLP), juntamente com a quantificação destas comunidades por meio da PCR em tempo real (qPCR) em 476 amostras de solo, obtidas de 11 áreas de cultivo (usinas). Dentro deste conjunto de dados, temos que os atributos químicos, físicos e manejo explicam maiores valores de variância dentro de cada área amostra, mas pouco explicam da variância geral dos dados, sugerindo a ocorrência de padrões biogeográficos das comunidades de fungos neste ambiente. Tal ocorrência foi confirmada pela significância estatística da correlação entre distância e dissimilaridade das comunidades de fungos, dando suporte a geração dos primeiros mapas biogeográficos de fungos em tais solos. Adicionalmente, a abundância de fungos mostrou-se relacionada com a produtividade da cultura, indicando este ser um dos fatores que modulam a produtividade de cana-de-açúcar nas áreas avaliadas.

Julia Elidia de Lima. Diversidade microbiana envolvida na ciclagem do nitrogênio em solos de cultivo de cana-de-açúcar no Estado de São Paulo. Início: 2012. Doutorado em Microbiologia Agrícola - Escola Superior de Agricultura Luiz de Queiroz - USP. Bolsista FAPESP.

Resumo: A cana-de-açúcar é a cultura de maior relevância agrícola atualmente no Estado de São Paulo, onde existem três regiões de cultivo; duas áreas consideradas mais antigas e uma área de expansão da cultura, com distintos manejos encontrados em cada uma das áreas. Visando a produtividade e a sustentabilidade desta cultura, o papel que a comunidade microbiana envolvida no ciclo do nitrogênio presente nos solos desempenha é de grande importância, uma vez que este elemento é essencial para as plantas. Contudo, pouco se sabe sobre a comunidade envolvida neste ciclo biogeoquímico em solos cultivados com canade-açúcar. Dessa forma, este projeto tem como objetivo descrever a diversidade microbiana relacionada ao ciclo do nitrogênio nos solos de cana-de-açúcar no estado de São Paulo, englobando o grupo das bactérias e arquéias amônio oxidantes, bactérias fixadoras de nitrogênio, e bactérias promotoras da desnitrificação. Propõe-se utilizar metodologias independentes de cultivo para quantificar estas comunidades por meio da aplicação de PCR em tempo real (qPCR), analisar a estrutura dessas comunidades microbianas por polimorfismo de comprimento de fragmentos de restrição terminal (TRFLP), além de determinar a afiliação filogenética destes microrganismos por pirosequenciamentos dos genes alvo. Por fim, os dados microbiológicos serão correlacionados com as características físicoquímicas dos solos analisados, resultando em um estudo de diversidade microbiana envolvida no ciclo do nitrogênio nestes solos no estado de São Paulo.

Thiago Gumiere. Biogeografia microbiana em solos de cana-de-açúcar. Início: 2013. Doutorado em Solos e Nutrição de Plantas - Escola Superior de Agricultura Luiz de Queiroz - USP. Bolsista FAPESP.

Resumo: O Brasil é o maior produtor mundial de cana-de-açúcar, sendo seus principais derivados o álcool e o açúcar, que abastecem principalmente os mercados de combustíveis e as indústrias alimentícias. Suas áreas de cultivo, em constante expansão, abrangem distintas variações de temperatura e precipitação, havendo também diferenças quanto aos sistemas de plantio, manejo da quantidade de palha no campo e rotação de culturas com leguminosas. Para isto, dentre outros fatores, o papel da comunidade microbiana 
presente nos solos pode ter fundamental importância, auxiliando no melhor desenvolvimento da planta. No entanto, pouco se sabe sobre a comunidade microbiana existente nos solos cultivados com cana-deaçúcar, ou mesmo sobre sua diferenciação ao longo do tempo de condução da cultura. Diante disso um estudo biogeográfico poderá trazer benefícios voltados ao entendimento desta distribuição espacialtemporal dos microrganismos no solo. Além disso, esta abordagem permitirá uma melhor compreensão da hierarquia de variáveis ambientais, como atributos físicos e químicos do solo, propriedades climáticas, práticas de manejo agrícola, e cobertura vegetal, fundamentais para uma visão extensa da ecologia microbiana e da sua funcionalidade no ecossistema. Portanto, esta proposta tem como objetivo identificar e mapear a diversidade de bactérias e fungos em solos de cultivo de cana-de-açúcar, avaliando a influência ao longo do tempo, dos fatores clima, rotação de cultura, sistemas de manejo e quantidade de palha. Propõe-se a quantificação destas comunidades por meio da aplicação de PCR em tempo real (qPCR), a análise da estrutura das comunidades microbianas por polimorfismo de comprimento de fragmentos de restrição terminal (T-RFLP), e a determinação da filogenia dos organismos analisados por Íon Torrent ${ }^{\circledR}$ de genes alvos. Os locais amostrados serão áreas experimentais nas usinas Iracema, Boa Vista (ambas do Grupo São Martinho), Quatá (Grupo Zilor), e Porto das Águas (Grupo Cerradinho), localizadas nos municípios de Iracemápolis, Quirinópolis, Quatá e Chapadão do Céu, respectivamente. As variáveis consideradas serão, primeiramente, a diferença climática entre os locais. Em seguida, serão avaliadas as práticas de rotação com Crotalaria spectabilis antes do plantio da cana; o sistema de manejo (convencional plantio direto e plantio direto com tráfego reduzido); e a quantidade de palha no campo. O monitoramento das áreas será realizado nos dois semestres do primeiro ano e no segundo semestre do segundo, tendo, portanto, a duração de 2 anos. Portanto, este projeto permitirá a realização de um mapeamento temporal da comunidade microbiana em solos cultivados com cana-de-açúcar. Além disso, poderão ser estabelecidas relações entre as variações destas comunidades em função das distintas práticas de manejo adotadas, o que auxiliará na escolha de práticas mais sustentáveis e rentáveis para a cultura canavieira.

Ademir Durrer Bigaton. Diversidade de bactérias e arquéias em solos com cultivo de cana-deaçúcar no Estado de São Paulo: um enfoque biogeográfico. Início: 2011. Doutorado em Microbiologia Agrícola - Escola Superior de Agricultura Luiz de Queiroz - USP. Bolsista FAPESP.

Resumo: A cana-de-açúcar é atualmente a cultura de maior importância agrícola do Estado de São Paulo, onde se almeja uma menor expansão das fronteiras agrícolas. Atualmente, o zoneamento agroclimático descreve a existência de três regiões de cultivo de cana-de-açúcar, sendo duas áreas mais antigas, com distintos padrões ambientais aptos para este cultivo, além de uma nova área, recentemente ocupada por esta cultura. Dento de um contexto de maior produtividade e sustentabilidade desta cultura, dentre outros fatores, o papel da comunidade microbiana presente nos solos pode ter fundamental importância, auxiliando no melhor desenvolvimento da planta, seja suprindo a mesma com nutrientes, ou diminuindo a ocorrência de doenças e pragas. Contudo, pouco se sabe sobre a comunidade microbiana existente nos solos cultivados com cana-de-açúcar. Dessa forma, este projeto tem como objetivo descrever, em um enfoque biogeográfico, a diversidade microbiana existente em solos de cana-de-açúcar do Estado de São 
Paulo, englobando os grupos de arquéias e bactérias. Propõe-se quantificar estas comunidades por meio da aplicação de PCR em tempo real (qPCR), analisar a estrutura das comunidades microbianas por polimorfismo de comprimento de fragmentos de restrição terminal (T-RFLP), e determinar a afiliação filogenética destes organismos por pirosequenciamento de genes alvos. Dentro deste contexto, dois tipos de amostragens serão realizados com a finalidade de: i) comparar as variações que ocorrem em macroescala, entre as diferentes áreas descritas pelo zoneamento agroclimático, e ii) obter padrões em microescala das comunidades avaliadas dentro de cada uma das áreas deste zoneamento. Por fim, os dados microbiológicos obtidos serão correlacionados com as características físico-químicas dos solos analisados, resultando em um estudo biogeográfico dos solos amostrados e no mapeamento microbiológico de solos com cultivo de cana-de-açúcar no Estado de São Paulo.

\section{Diogo Paes da Costa. Descrição da comunidade microbiana associada à rizosfera de cana-de-} açúcar. 2013. Mestrado em Solos e Nutrição de Plantas, Escola Superior de Agricultura Luiz de Queiroz - USP. Bolsista FAPESP.

Resumo: A cana-de-açúcar é uma cultura importante no contexto agrário brasileiro, sobretudo com relação a manutenção e sustentabilidade dos agroecossistemas e da biodiversidade do solo. As comunidades microbianas associadas à cana-de-açúcar são participantes da manutenção dos ciclos biogeoquímicos, podendo ter sua estrutura e diversidade alteradas por mudanças no manejo da cultura e nas condições climáticas. Esse estudo teve como objetivo avaliar a diversidade microbiana associada à rizosfera de diferentes genótipos de cana-de-açúcar e empregar a metodologia de Stable Isotope Probing (DNA-SIP) para se avaliar a estrutura dos grupos responsivos a este ambiente. Para tanto, variedades de cana-deaçúcar foram selecionadas, extraindo-se o DNA total rizosférico e do bulk soil para análise por PCRDGGE das regiões do gene $16 \mathrm{~S}$ rDNA de bactérias, selecionando-se amostras representativas para o sequenciamento da região V6 do gene 16S rDNA através da plataforma Ion Torrent ${ }^{\mathrm{TM}}$. Os resultados demonstraram diferenças entre a diversidade das comunidades microbianas da rizosfera e do bulk soil, havendo a predominância dos grupos Actinobacteria, Proteobacteria e Acidobateria. Para o estudo da estrutura dos grupos responsivos na rizosfera, plantas da variedade RB86-7515 foram cultivadas sob duas concentrações de $\mathrm{CO}_{2}$ (350 e $700 \mathrm{ppm}$ ), realizando-se o enriquecimento com ${ }^{13} \mathrm{CO}_{2}$, e posteriormente realizando a extração do DNA rizosférico para aplicação na técnica de DNA-SIP. A eficiência desta técnica foi avaliada por meio da técnica de PCR-DGGE para as regiões 16S rDNA de bactérias e ITS de fungos, onde foi verificado que após 48 horas já ocorre a incorporação de ${ }^{13} \mathrm{C}$ pelas comunidades microbianas, havendo diferença entre os grupos que incorporaram o ${ }^{13} \mathrm{C}$. Diferenças foram também observadas para as distintas concentrações de $\mathrm{CO}_{2}$, indicando o DNA-SIP como uma poderosa ferramenta de estudos da ecologia das comunidades microbianas na rizosfera de cana-de-açúcar.

Danice Mazzer Luvizotto. Estudo da estrutura da comunidade bacteriana rizosférica de cana-deaçúcar por hibridização fluorescente in situ. Bolsista CNPq - Pós-doutorado Júnior (maio de 2013 a maio de 2014)

Resumo: O Brasil é o maior produtor mundial de cana-de-açúcar, sendo o cultivo desta planta alvo de incentivos federais desde a década de 70, visando a geração e aprimoramento de uma fonte alternativa de 
energia sustentável e renovável. Dentre os diversos fatores envolvidos no aumento de produtividade de cana-de-açúcar, vale ressaltar que pouco se conhece sobre a estrutura e diversidade da microbiota associada a esta cultura. Visando melhorar o papel deste tipo de interação no cultivo de cana-de-açúcar no Brazil, é imprescindível um estudo amplo da diversidade microbiana, englobando seus diferentes aspectos. Dentre estes aspetos, destaca-se a necessidade de um maior entendimento sobre a estruturação, interação e funcionamento destas comunidades na rizosfera da cana-de-açúcar. Tais interações são essenciais no estabelecimento, desenvolvimento e proteção das plantas contra patógenos, apresentando diversas funções tais como produção de fitohormônios, enzimas, bem como auxiliando na disponibilização de nutrientes (e.g. nitrogênio, fósforo), etc. Entretanto, sabe-se que diversos fatores podem influenciar na flutuação destas comunidades, principalmente àqueles relacionados a fatores ambientais (e.g. pH, temperatura, estrutura do solo) e manejo agrícola. Devido a não culturabilidade da grande maioria dos microrganismos, a aplicação de técnicas baseadas na detecção e análise de ácidos nucléicos mostra-se indispensável para acessar e estudar estas comunidades. Assim sendo, diversos estudos vêem descrevendo a diversidade microbiana ambiental principalmente por meio do acesso e análise de informações contidas em sequências nucleotídicas do gene 16S RNAr. Adicionalmente, o monitoramento in situ destas comunidades mostrou-se possível pelo desenvolvimento e constante aprimoramento da técnica de Hibridização Fluorescente in situ (FISH), a qual tem permitido rápida identificação de bactérias, e entendimento da estruturação de comunidades microbianas nos mais diferentes ambientes. Esta técnica se utiliza de sondas fluorescente, sintetizadas a partir de sequências do gene 16S RNAr, as quais oferecem facilidade e precisão na identificação de diversos grupos microbianos. Quando comparada com técnicas dependentes de cultivo, a hibridização com sondas de ácidos nucléicos é rápida e segura; e pode ser utilizada de forma quantitativa. Desta forma, a proposta deste projeto tem como objetivo geral estudar os principais grupos bacterianos associados a rizosfera de cana-de-açúcar, e verificar alterações que ocorrem na estruturação de tais comunidades devido ao uso de diferentes manejos desta cultura. Espera-se portanto, revelar de forma robusta e inovadora, as identidades dos principais grupos microbianos que interagem durante a formação deste 'escudo' microbiano sobre as raízes de plantas de cana-de-açúcar.

Costa, D.P.; Dias, A.C.F.; Durrer, A.; Andrade, P.A.M.; Gumiére, T.; Andreote, F.D. Composição diferencial das comunidades bacterianas na rizosfera de variedades de cana-de-açúcar. Revista Brasileira de Ciência do Solo, submetido.

Resumo: A cultura da cana-de-açúcar é de extrema importância no cenário agrícola nacional. No entanto, pouco se sabe sobre a estruturação das comunidades microbianas associadas aos solos e rizosferas de tais plantas. O objetivo desse trabalho foi avaliar a estrutura e a diversidade das comunidades de bactérias associadas ao solo e a à rizosfera de seis variedades de cana-de-açúcar cultivadas no Brasil. As análises foram realizada com base em métodos independentes de cultivo, onde a técnica de PCR-DGGE revelou alterações na rizosfera para os grupos de bactérias totais, e também para os grupos de Alphaproteobacteria e Betaproteobacteria. Após esta análise, quatro amostras (três de rizosfera e uma de solo) foram usadas para o sequenciamento da região V6 do gene 16S DNAr na plataforma IonTorrent ${ }^{\mathrm{TM}}$. Esta análise gerou um total de 95.812 sequências, dentro das quais houve a predominância das afiliadas aos filos 
Actinobacteria, Proteobacteria e Acidobateria. Os resultados revelaram que as comunidades bacterianas na rizosfera são distintas daquelas encontradas no solo. Foi possível ainda observar um efeito diferencial de plantas das distintas variedades. Alguns grupos bacterianos apresentaram menor frequência na rizosfera (Acidobacteria); enquanto outros mostraram-se fortemente estimulados pela presença das raízes, comumente para todas as variedades (Betaproteobacteria, Nitrospora e Chloroflexi), ou em respostas variedade-específicas (Bacilli e Sphingobacteria).

Pedro Avelino Maia de Andrade. A composição da comunidade bacteriana do solo como fator determinante na micorrização de cana-de-açúcar por Glomus clarum. 2013. Mestrado em Solos e Nutrição de Plantas, Escola Superior de Agricultura Luiz de Queiroz - USP. Bolsista CNPq.

Resumo: A cana-de-açúcar é uma das principais culturas do sistema agrícola brasileiro, e apresentase atualmente em plena expansão. Porém o uso do solo e a implementação de diferentes tecnologias de manejo têm originado alterações no equilíbrio ambiental, onde importantes interações microbianas ocorrem de forma essencial para o desenvolvimento vegetal. Dentre a vasta diversidade de microrganismos do solo, destacam-se os fungos micorrízicos, organismos intimamente associados as raízes das plantas, auxiliando a mesma, dentre outras formas, na obtenção de água e nutrientes. Estes fungos no entanto, interagem também com outros organismos do solo, como por exemplo, com a comunidade bacteriana presente neste ambiente. Desta forma, o presente trabalho buscou estudar a dinâmica de interação entre cana-de-açúcar e o fungo micorrízico arbuscular (FMA) G. clarum em solos com diferentes composições da comunidade bacteriana. A metodologia utilizada foi a 'diluição para extinção', onde diluições seriadas $\left(10^{-1} ; 10^{-3} ; 10^{-6}\right.$ e $\left.10^{-9}\right)$ de um solo natural foram usadas para inocular o solo estéril. Sobre esta base, foram monitoradas pelo período de 60 dias, a colonização da planta pelo FMA e a estruturação das comunidades bacterianas. Como resultado, foi observada uma maior colonização das raízes de cana-de-açúcar para os tratamentos inoculada com menores diluições da comunidade original (solo natural e diluições $10^{-1}$ e $10^{-3}$ ), sendo da mesma forma observada uma distinção entre as comunidades bacterianas destes tratamentos para os demais. Estabelecendo correlações entre os grupos microbianos e as taxas de colonização micorrízica, foi possível nomear, com base no sequenciamento massivo da região V6 do gene ribossomal 16S DNAr, a alteração conjunta da micorrização com mudanças nos grupos de Actinobacteria, Bacteriodetes, Firmicutes, Proteobacteria, Verrucomicrobia e Acidobacteria. Concluindo, este trabalho demonstra a dependência que um processo importante, como a micorrização, possui da comunidade bacteriana do solo, e indica que em áreas degradadas, com menores níveis de diversidade bacteriana, tal processo pode ocorrer com menor eficiência. 
Dorotéia Alves Ferreria. Interação de fungos micorrízicos com a diversidade bacteriana em solos de cana-de-açúcar. Início: 2012. Doutorado em Solos e Nutrição de Plantas - Escola Superior de Agricultura Luiz de Queiroz - USP. Bolsista FAPESP.

Resumo: O Brasil é o maior produtor da cultura de cana-de-açúcar e o estado de São Paulo se destaca como maior produtor nacional. A cana-de-açúcar assume relevante importância energética, alimentícia, ambiental e socioeconômica no país. Diversos fatores contribuem para o sucesso do cultivo dessa cultura, sendo importante considerar as características climáticas e as interações microbiológicas que ocorrem no solo, propiciando maior sustentabilidade de produção devido à manutenção de diversos processos biogeoquímicos. No entanto, se conhece pouco sobre a comunidade microbiana do solo cultivado com cana-de-açúcar e as suas interações com microrganismos importantes para a funcionalidade dos ecossistemas, como os fungos micorrízicos arbusculares (FMAs). Este projeto tem como proposta principal o entendimento da dinâmica que ocorre, devido a alterações impostas na estrutura da comunidade microbiana, sobre a interação com espécies de FMAs encontrados nos solos cultivados com cana-de-açúcar. Propõe-se avaliar três espécies de FMAs (Glomus clarum, Acaulospora sp. e Scutellospora sp.) em diferentes situações de diversidade da comunidade microbiana (diversidade microbiana do solo natural, solo estéril, e três níveis intermediários de diversidade), estabelecidos por meio da inoculação de diluições do extrato natural do solo $\left(10^{-3}, 10^{-6}\right.$ e $\left.10^{-9}\right)$ em solo estéril. Para avaliação serão consideradas as taxas de colonização micorrízica das plantas de cana-de-açúcar, a diversidade de bactérias e fungos em cada tratamento e a matéria seca da parte aérea das plantas. Os perfis das comunidades microbianas serão determinados por meio da extração do DNA do solo, amplificação de genes alvo pela reação em cadeia de polimerase (PCR) e análise por polimorfismo de comprimento de fragmentos de restrição terminal (T-RFLP). Pretende-se, correlacionar os dados obtidos com coletas realizadas em áreas de cultivo de cana-de-açúcar para observar a estrutura da comunidade microbiana e os mecanismos que resultam no estabelecimento dos principais grupos bacterianos e de FMAs, culminando nas complexas interações microbianas nestes solos. Além de observar quais grupos bacterianos interagem com as espécies de FMAs estudadas e se estes prevalecem em cultivo de larga escala. 


\section{Anexo II - Características físicas e químicas dos solos de biomas naturais que compõem este documento}

Anexo II.1. Características físicas e químicas dos solos da caatinga utilizados nos estudos descritos neste documento.

\begin{tabular}{|c|c|c|c|c|c|}
\hline \multirow[t]{2}{*}{ Características } & \multicolumn{5}{|c|}{ Áreas de Estudo } \\
\hline & Área 1 (BA) & Área 2 (PI) & Área 3 (CE) & Área 4 (PB) & Área $5(\mathrm{RN})$ \\
\hline$p H$ & $5,8 \pm 0,0$ & $4,1 \pm 0,1$ & $6,2 \pm 0,0$ & $5,2 \pm 0,1$ & $5,6 \pm 0,1$ \\
\hline$M O g / d m^{3}$ & $24,5 \pm 0,3$ & $20,5 \pm 0,3$ & $24,0 \pm 0,0$ & $24,5 \pm 0,3$ & $37,0 \pm 0,0$ \\
\hline$P\left(m g d m^{-3}\right)$ & $5,0 \pm 0,0$ & $15,0 \pm 0,6$ & $3,0 \pm 0,0$ & $3,5 \pm 0,3$ & $49,5 \pm 10,1$ \\
\hline$K\left(m g d m^{-3}\right)$ & $2,5 \pm 0,1$ & $0,7 \pm 0,0$ & $1,4 \pm 0,0$ & $3,6 \pm 0,1$ & $6,4 \pm 0,2$ \\
\hline $\mathrm{Ca}\left(m g d m^{-3}\right)$ & $31,5 \pm 0,3$ & $4,5 \pm 0,3$ & $39,0 \pm 0,0$ & $19,5 \pm 1,4$ & $50,5 \pm 3,2$ \\
\hline$M g\left(m g d m^{-3}\right)$ & $6,0 \pm 0,0$ & $1,0 \pm 0,0$ & $24,0 \pm 0,0$ & $6,0 \pm 0,6$ & $12,0 \pm 0,6$ \\
\hline$H+l\left(m m o l d m^{-3}\right)$ & $17,0 \pm 0,6$ & $32,5 \pm 0,8$ & $15,0 \pm 0,0$ & $22,0 \pm 0,0$ & $23,5 \pm 0,9$ \\
\hline$S B\left(m m o l d m^{-3}\right)$ & $39,4 \pm 0,2$ & $6,5 \pm 0,1$ & $63,9 \pm 0,0$ & $29,3 \pm 2,0$ & $69,1 \pm 4,2$ \\
\hline$C E C$ & $56,7 \pm 0,3$ & $39,0 \pm 0,9$ & $78,7 \pm 0,0$ & $51,8 \pm 2,0$ & $92,9 \pm 4,9$ \\
\hline$V \%$ & $69,0 \pm 0,9$ & $17,0 \pm 0,6$ & $81,0 \pm 0,0$ & $56,0 \pm 1,7$ & $74,0 \pm 0,6$ \\
\hline$B\left(m g d m^{-3}\right)$ & $0,3 \pm 0,0$ & $0,2 \pm 0,0$ & $0,1 \pm 0,0$ & $0,1 \pm 0,0$ & $0,2 \pm 0,0$ \\
\hline$C u\left(m g d m^{-3}\right)$ & $0,6 \pm 0,0$ & $0,2 \pm 0,1$ & $1,0 \pm 0,0$ & $0,2 \pm 0,0$ & $0,5 \pm 0,1$ \\
\hline$F e\left(m g d m^{-3}\right)$ & $12,0 \pm 0,0$ & $125,0 \pm 10,9$ & $76,0 \pm 0,7$ & $67,0 \pm 0,6$ & $50,0 \pm 2,3$ \\
\hline$M n\left(m g d m^{-3}\right)$ & $21,0 \pm 0,3$ & $3,2 \pm 0,1$ & $51,0 \pm 0,0$ & $18,5 \pm 0,7$ & $41,4 \pm 3,4$ \\
\hline$Z n\left(m g d m^{-3}\right)$ & $0,7 \pm 0,0$ & $4,8 \pm 0,7$ & $12,3 \pm 0,0$ & $3,7 \pm 0,1$ & $7,2 \pm 0,5$ \\
\hline
\end{tabular}


Anexo II.2. Características físicas e químicas dos solos da Mata Atlântica utilizados nos estudos descritos neste documento.

\begin{tabular}{lccc}
\hline \multicolumn{1}{c}{ Características } & & Áreas de Estudo \\
\cline { 2 - 4 } & Santa Virginia & Picinguaba & Restinga \\
\hline Areia \% & $55,9 \pm 2,3$ & $56,8 \pm 1,7$ & $87,8 \pm 1,2$ \\
Silte \% & $12,3 \pm 1,7$ & $11,3 \pm 0,6$ & $46,7 \pm 18,9$ \\
Argila \% & $31,2 \pm 2,3$ & $31,8 \pm 1,1$ & $52,5 \pm 30,6$ \\
pH & $3,6 \pm 0,1$ & $3,6 \pm 0,1$ & $3,6 \pm 0,2$ \\
$M O ~ g / m^{3}$ & $70,2 \pm 11,3$ & $63,7 \pm 5,6$ & $62,0 \pm 5,7$ \\
$P\left(m g d m^{-3}\right)$ & $15,2 \pm 1,7$ & $13,0 \pm 3,6$ & $5,2 \pm 0,5$ \\
$K\left(m g d m^{-3}\right)$ & $1,9 \pm 0,5$ & $1,7 \pm 0,3$ & $0,8 \pm 0,1$ \\
$C a\left(m g d m^{-3}\right)$ & $2,3 \pm 0,5$ & $2,3 \pm 0,5$ & $1,0 \pm 0,0$ \\
$M g\left(m g d m^{-3}\right)$ & $2,2 \pm 0,5$ & $2,0 \pm 0,00$ & $1,0 \pm 0,0$ \\
$H+A l\left(\mathrm{mmol} \mathrm{dm}^{-3}\right)$ & $23,3 \pm 1,0$ & $20,3 \pm 0,8$ & $16,5 \pm 2,3$ \\
$S\left(m g d m^{-3}\right)$ & $9,6 \pm 1,2$ & $13,0 \pm 0,8$ & $5,3 \pm 0,5$ \\
$C\left(m g d m^{-3}\right)$ & $0,6 \pm 0,2$ & $0,4 \pm 0,3$ & $0,1 \pm 0,0$ \\
$M n\left(m g d m^{-3}\right)$ & $3,1 \pm 0,6$ & $3,9 \pm 1,0$ & $0,7 \pm 0,2$ \\
$Z n\left(m g d m^{-3}\right)$ & $1,0 \pm 0,2$ & $0,9 \pm 0,2$ & $0,7 \pm 0,2$ \\
\hline
\end{tabular}


Anexo II.3. Características físicas e químicas dos solos de manguezais utilizados nos estudos descritos neste documento.

\begin{tabular}{|c|c|c|c|c|}
\hline \multirow[t]{2}{*}{ Características } & \multicolumn{4}{|c|}{ Áreas de Estudo } \\
\hline & BrMg01 & BrMg02 & BrMg03 & BrMg04 \\
\hline Areia \% & $27 \pm 0,0$ & $53,0 \pm 16,0$ & $48,5 \pm 2,5$ & $78,5 \pm 6,5$ \\
\hline Silte \% & $42,5 \pm 3,5$ & $37,0 \pm 16,0$ & $32 \pm 2,0$ & $7,0 \pm 2,0$ \\
\hline Argila \% & $30,5 \pm 2,5$ & $10,0 \pm 0,0$ & $19,5 \pm 0,5$ & $14,5 \pm 4,5$ \\
\hline Umidade (\%) & $59,1 \pm 3,0$ & $75,0 \pm 5,4$ & $71,4 \pm 2,5$ & $48,8 \pm 14,0$ \\
\hline$p H$ & $5,4 \pm 0,5$ & $6,3 \pm 0,0$ & $6,0 \pm 0,9$ & $6,9 \pm 0,0$ \\
\hline$M O g / d^{3}$ & $129,5 \pm 1,5$ & $271,0 \pm 52,2$ & $235,7 \pm 7,3$ & $71,0 \pm 14,0$ \\
\hline$P\left(m g d m^{-3}\right)$ & $24,5 \pm 9,5$ & $37,0 \pm 8,0$ & $56,0 \pm 5,0$ & $6,0 \pm 1,0$ \\
\hline$K\left(m g d m^{-3}\right)$ & $4,8 \pm 1,9$ & $11,7 \pm 1,9$ & $12,4 \pm 0,8$ & $7,25 \pm 1,0$ \\
\hline $\mathrm{Ca}\left(m g d m^{-3}\right)$ & $51,0 \pm 2,0$ & $183,0 \pm 9,0$ & $78,5 \pm 7,8$ & $51,0 \pm 15,0$ \\
\hline$M g\left(m g d m^{-3}\right)$ & $124,0 \pm 29,1$ & $239,5 \pm 92,8$ & $161,7 \pm 8,3$ & $93,5 \pm 22,6$ \\
\hline$H+A l\left(m m o l d m^{-3}\right)$ & $48,0 \pm 10,0$ & $36,5 \pm 5,5$ & $31,2 \pm 3,3$ & $27,5 \pm 5,5$ \\
\hline$S B\left(\mathrm{mmol} \mathrm{dm} \mathrm{m}^{-3}\right)$ & $179,4 \pm 29,5$ & $434,4 \pm 85,6$ & $253,2 \pm 1,3$ & $151,4 \pm 38,6$ \\
\hline CTC & $227,4 \pm 39,5$ & $470,9 \pm 79,7$ & $284,2 \pm 2,1$ & $179,0 \pm 43,8$ \\
\hline$V \%$ & $79,0 \pm 1,0$ & $91,5 \pm 2,5$ & $88,7 \pm 1,3$ & $82,7 \pm 0,3$ \\
\hline$E h(m V)$ & $390,5 \pm 44,6 b$ & $123,0 \pm 101,3$ & $180,2 \pm 18,3$ & $438,0 \pm 22,1$ \\
\hline
\end{tabular}

